$$
\begin{gathered}
\text { Universidade de São Paulo } \\
\text { Faculdade de Filosofia, Letras e Ciências Humanas } \\
\text { Departamento de Letras Modernas }
\end{gathered}
$$

Programa de Pós-Graduação em Estudos Lingüísticos e Literários de Língua

Inglesa

\title{
A OUTRA LÍNGUA EM UM FILME HOLLYWOODIANO: Um espaço destinado ao estrangeiro em "Nova York Sitiada"
}

\section{WILSON CHEQUI}

Dissertação apresentada à Faculdade de Filosofia, Letras e Ciências Humanas da Universidade de São Paulo, como parte dos requisitos para a obtenção do grau de Mestre na área de Estudos Lingüísticos e Literários de Língua Inglesa, sob a orientação da Professora Dra. Marisa Grigoletto.

São Paulo

Julho 2008 


$$
\begin{gathered}
\text { Universidade de São Paulo } \\
\text { Faculdade de Filosofia, Letras e Ciências Humanas } \\
\text { Departamento de Letras Modernas }
\end{gathered}
$$

Programa de Pós-Graduação em Estudos Lingüísticos e Literários de Língua

Inglesa

\section{A OUTRA LÍNGUA EM UM FILME HOLLYWOODIANO: Um espaço destinado ao estrangeiro em "Nova York Sitiada”}

\section{WILSON CHEQUI}

São Paulo

Julho 2008 
A meus pais, Sr. Antonio e

D. Maria, por óbvias razões,

e Marisa Grigoletto,

pela sábia e paciente orientação. 


\section{AGRADECIMENTOS}

Profa. Cibele Mara Dugaich, por me apresentar à Análise do Discurso de maneira tão cativante e pelo incentivo a investir neste projeto, e Profa. Sônia Prado, pelas palavras sempre encorajadoras e pela extensa e rica bibliografia sugerida em suas aulas. Ana Paula Landi, por ter acompanhado de perto (literalmente) o início de meu ingresso no programa, Wilma Moura, por ter sempre compreendido as razões de minhas pausas editoriais em função dos estudos, e Leni Lobo, pelas sonoras palavras de estímulo por ocasião ainda do processo de seleção do programa. Professoras Deusa M. S. P. Passos e Maria Teresa (Maite) Celada, Professores Jorge do Ó, Marcos Cesar de P. Soares, Leland Emerson McCleary e Lynn Mario T. Menezes de Souza, cujas contribuições foram e têm sido fundamentais para o desenvolvimento do trabalho. De modo especial, Profa. Maria Onice Payer, pelo que sua leitura de um de meus trabalhos representou no encaminhamento da pesquisa para o aspecto específico da língua. A todas as pessoas do grupo de estudo, sem as quais as reuniões não existiriam e o amadurecimento necessário do projeto não ocorreria. Lúcia Matuda, pelos livros e palavras de incentivo. Leonor Sá, que talvez sem o saber, um dia me mostrou com seu exemplo que esse caminho era possível. Chris Evers e Gisele Libutti, pelo auxílio com algumas imagens. Wagner, pelo carinho e amizade. Todas as pessoas cujos nomes eu poderia mencionar nas páginas seguintes, mas que (sempre a heterogeneidade constitutiva do discurso!) estão nelas presentes mesmo não citadas, "falando" de alguma maneira por meio de palavras que apenas momentaneamente julgo minhas. E a Deus, sempre... 


\title{
RESUMO
}

A produção incessante de filmes em Hollywood se organiza de acordo com alguns gêneros principais que comportam, cada um, características pré-definidas em termos de conteúdo. Ao longo das três últimas décadas, um sub-gênero do "terror" (o filme sobre terrorismo) se desenvolveu, reforçando uma tendência já existente de produzir filmes catástrofe. Essa nova categoria ofereceu outras possibilidades de roteiros, e dentre os inúmeros títulos que abordam o terrorismo, The Siege (Nova York Sitiada), lançado dois anos após um ataque contra o exército dos EUA na Arábia Saudita, em 1996, se destaca. Tais roteiros pressupõem o conflito, daí a imprescindibilidade da figura da antítese, por vezes apenas como um substrato narrativo devido a suscetibilidades do período histórico em questão. Nessas tramas, o inimigo é invariavelmente estrangeiro, o que requer, entre outros elementos necessários para sua representação, a destinação de um espaço para o seu dizer, oportunidade que pode revelar a presença de uma língua outra no filme além do inglês. Ancorado em pressupostos teóricos da Análise do Discurso de linha francesa, este trabalho investiga, em trechos pré-selecionados, as representações sobre os modos de dizer associados a essa alteridade (no caso, o personagem árabe), refletindo também acerca do mesmo tipo de representação que, por oposição, fica associado ao sujeito a partir de cujo olhar todas essas construções são materializadas. O trabalho procura observar, sempre a partir dessa noção de espaço destinado ao dizer, como se dá o processo de identificação no filme - ou seja, a reconhecer os tipos de identidade construídos para ambos os personagens (oriental e ocidental) que, no complexo dos trechos analisados, se contrapõem.

Palavras-chave: Cinema; Alteridade; Representação; Discurso; Língua; Identidade; Oriente; Ocidente

\begin{abstract}
The continuous production of movies in Hollywood is organized according to certain major genres, each of which allows for predefined features in terms of contents. Over the last three decades, a subgenre of "terror" (the terrorist movie) has developed, reviving an existing tendency to produce catastrophe movies. This new category has offered other possibilities of screenplays. Among the number of titles which deal with terrorism, “The Siege”, released two years after the 1996 attack on the US military in Saudi Arabia, stands out. Such screenplays presuppose conflict and the antithetical figure therefore becomes fundamental, even if only as a narrative substratum due to the susceptibilities of the historic period in question. In these plots, the enemy is invariably a foreigner, thus requiring, among other necessary elements for his representation, the reservation of a space for verbal expression. This is an occasion which can reveal the presence of a language other than English in the movie. Anchored in the theoretical principles of French school Discourse Analysis, this dissertation investigates, in pre-selected excerpts, the representations of the modes of verbal expression associated with this alterity (the Arab character, in this case). This dissertation attempts to observe, always based on this notion of space reserved for the modes of verbal expression, how the process of identification occurs in the movie - in other words, to recognize the types of identity constructed for both characters (eastern and western) that, in the complex of the excerpts analyzed, serve as counterpoints.
\end{abstract}

Key-words: Cinema; Alterity; Representation; Discourse; Language; Identity; the East; the West 


\section{SUMÁRIO}

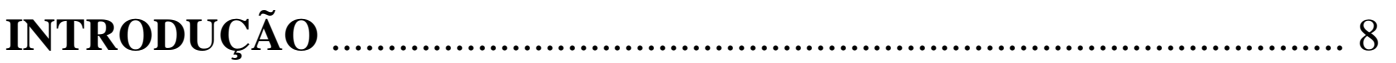

CAPÍTULO I - A abordagem discursiva do texto

1.1 Apresentação ........................................................................................... 16

1.2 A Análise do Discurso (AD) francesa ......................................................... 16

1.3 A AD como dispositivo de análise fílmica e a questão da identificação ........ 18

1.4 A representação como construção ............................................................ 21

CAPÍTULO II - Desenvolvimento do cinema hollywoodiano

2.1 O nickleodeon e a representação sobre o outro ............................................. 25

2.2 A instalação da estrutura clássica hollywoodiana .......................................... 26

$2.3 \mathrm{O}$ discurso sobre o outro em The birth of a nation ....................................... 30

2.4 A obsessão pela catástrofe no gênero "terrorismo” "..................................... 36

\section{CAPÍTULO III - O Oriente na visão ocidental}

3.1 Apresentação .......................................................................................... 41

3.2 Oriente: do florescimento à sua tradição ...................................................... 44

3.3 A inscrição do oriental árabe nos filmes de Hollywood ................................ 49

3.4 A racionalidade como contraponto entre o Oriente e o Ocidente ................. 54

CAPÍTULO IV - Observando os modos de silenciamento do outro em "Nova York Sitiada”

4.1 Apresentação ............................................................................... 60

4.2 Um corpo silente (mas presente) na seqüência de abertura ......................... 61

4.3 Representações da ininteligibilidade das palavras do outro ........................ 71

4.3.1 "Bombers of Bus 87”: a força como única linguagem .................. 73

4.3.2 Respostas que não respondem ................................................ 81

4.3.3 “Doory, dowry... or duty?”: múltiplos sentidos em uma palavra ... 85

4.3.4 Comunicando a incomunicabilidade ....................................... 91

4.4 Promovendo o reconhecimento sonoro e imagético da outra língua ........... 99

4.4.1 O nome da língua em uma proposição explicativa: inserção

incidente ou necessária? .................................................................... 100

4.4.2 As marcas de modalização no falar sobre a língua do outro .......... 105

CONSIDERAÇÕES FINAIS _................................................................ 114 
REFERÊNCIAS BIBLIOGRÁFICAS

ANEXO 1 (Ficha técnica de 'Nova York Sitiada' - The Siege)

\section{FIGURAS}

\begin{tabular}{|c|c|}
\hline Número da figura & Número da página \\
\hline 1 & 12 \\
\hline 2 & 13 \\
\hline 3 & 14 \\
\hline 4 & 31 \\
\hline 5 & 36 \\
\hline 6 & 42 \\
\hline 7 & 50 \\
\hline 8 & 63 \\
\hline 9 & 70 \\
\hline 10 & 70 \\
\hline 11 & 70 \\
\hline 12 & 78 \\
\hline 13 & 78 \\
\hline 14 & 79 \\
\hline 15 & 81 \\
\hline 16 & 83 \\
\hline 17 & 91 \\
\hline 18 & 97 \\
\hline 19 & 101 \\
\hline 20 & 102 \\
\hline 21 & 109 \\
\hline 22 & 109 \\
\hline 23 & 109 \\
\hline 24 & 109 \\
\hline 25 & 110 \\
\hline
\end{tabular}




\section{INTRODUÇÃO}

O produto da indústria cinematográfica de Hollywood, independentemente do modo como é disponibilizado, seja em versões legendadas ou dubladas, parece ter se incorporado nas mais diversas culturas ao redor do planeta. Acessível não apenas nas salas de cinema, mas em locadoras, livrarias, lojas de DVD, canais de televisão, e até mesmo em improvisadas instalações de vendedores ambulantes que se antecipam na comercialização de títulos ainda inéditos, é impossível não admitir uma certa onipresença do filme hollywoodiano. Contemplando os mais diversos gêneros, os estúdios de Hollywood não se restringem a produzir representações sobre a história do povo e do país sobre cujo solo começaram a se instalar a partir de 1910, mas investem muito de seu capital na produção de longa-metragens que também retratam outros povos e nações. Em outras palavras, produzem representações tanto sobre si como sobre o outro, e como observam Stam e Shohat (1997), "always in English” (p. 191). Povos em diferentes partes do globo acabam muitas vezes vendo suas culturas (ou aquilo que é promovido como sendo 'suas culturas’) sob as lentes dos cineastas dessa indústria de cinema com poder econômico sem paralelos no contexto mundial. São incontáveis os casos ilustrativos, mas para nos situar em dois contextos, um próximo e outro mais distante geograficamente, podemos nos referir às vezes em que o brasileiro já "se viu” nos musicais estrelados por Carmen Miranda nos anos de 1940 e àquelas em que os povos árabes ${ }^{1}$ "se viram” em filmes retratando o aspecto místico e exótico do Oriente. Esse caráter de ubiqüidade do produto hollywoodiano que resulta dos mais variados processos de reprodução, o ritmo de produção (filmes são lançados ao longo de todo o ano), o alcance e prestígio dessa indústria que podem ser comprovados anualmente por ocasião da premiação do Oscar, entre outros fatores ligados a Hollywood, cooperam no sentido de tornar sua produção cinematográfica desejável a investidores e multidões de espectadores que consomem o produto, nacional e internacionalmente. Nas locadoras brasileiras, como se sabe, esses filmes nem chegam a ser classificados como "estrangeiros” da maneira como ocorre com produções argentinas e alemãs, por exemplo. Disso resulta também o interesse de pesquisadores que, diante de um objeto tão multifacetado, encontram incontáveis possibilidades de abordagens e leituras.

Algumas das características atribuídas aos filmes hollywoodianos que costumam instigar o interesse de estudiosos incluem, entre outras, a tradição maniqueísta, a dominação

\footnotetext{
${ }^{1}$ Este termo é aqui utilizado no sentido mais amplo referente aos povos semitas de origem arábica.
} 
cultural e o reforço e perpetuação de estereótipos com a estigmatização de determinadas etnias em filmes sobre guerra e, em período mais recente, sobre terrorismo. É possível inteirar-se de como essas leituras são conduzidas em autores como Robert Stam, Douglas Kellner $^{2}$, Jack G. Shaheen ${ }^{3}$ e Edward Said, entre outros que reservam um espaço em suas pesquisas para abordar as representações sobre o outro na ficção hollywoodiana, entendendo este outro como o personagem não-americano e, invariavelmente, como a personificação da antítese dos valores representados no filme como corretos, desejáveis e universais.

A proposta deste trabalho não é criticar o grau de distanciamento - ou seja, as distorções - entre as representações do cinema e aquilo que no mundo real está associado ao objeto representado, pois partimos também do pressuposto de que um filme, qualquer que seja sua classificação, será, “a rigor, sempre ficcional, em qualquer de suas modalidades; sempre um fato de linguagem, um discurso produzido e controlado, de diferentes formas, por uma fonte produtora” (XAVIER, 2005:14). É evidente que o cinema não tem o compromisso de apresentar-se como retrato do real; entretanto, uma vez que o mesmo não pode ser produzido fora do contexto sócio-histórico em que está inserido, inevitavelmente se vê forçado, como sustenta Jameson (1995) acerca do cinema chamado comercial, a trabalhar com a "realidade social e os estereótipos de nossa experiência da realidade social cotidiana” (p. 39). Desse modo, faz-se necessário, a nosso ver, observar como se dá o funcionamento da produção e controle desses discursos dentro de determinadas condições de produção, na tentativa de tornar mais visível a presença (inevitável, diríamos) de aspectos ideológicos também em partes de um filme onde os mesmos possam parecer ausentes ou menos explícitos.

No filme (aqui considerando a obra na sua versão 'original', sem as legendas ou dublagens disponibilizadas nas cópias distribuídas em outros países) em que existe a inscrição do tipo de alteridade que descrevemos mais acima, é necessário representar a "sua” linguagem de alguma maneira, o que pode ocorrer com o uso do próprio idioma do personagem (com legendas explicativas em inglês ou não), ou no idioma instituído do filme, sempre o inglês. Nesta última hipótese, o outro é representado falando uma língua que, a rigor, não é “sua”, mas há casos em que essa alteridade tampouco intervém por meio da linguagem verbal, bastando que nos lembremos de personagens que participam de uma trama como figurantes ou coadjuvantes - ou seja, participantes que, especialmente do ponto de vista da hierarquia de

\footnotetext{
${ }^{2}$ Em sua obra A cultura da mídia: estudos culturais, identidade e política entre o moderno e o pós-moderno (Edusc, 2001), o autor desenvolve métodos e análises da produção contemporânea de filmes na indústria cinematográfica norte-americana.

${ }^{3}$ Autor do livro Reel bad Arabs: how Hollywood vilifies a people (Northampton: Interlink, 2001).
} 
valores observada na proporção de tempo de fala de um personagem para outro, se situam em um segundo ou terceiro plano em relação aos protagonistas. Além do fator lingüístico, é preciso representar de que modos o outro lida com a linguagem para que o espectador possa extrair dali (palavras, gestos, caracteres) algum sentido. Lançar um olhar sobre o modo como o espaço destinado a essas inscrições do outro se organiza para representá-lo está, de uma maneira mais ampla, no centro das preocupações deste trabalho. Também nos propomos a observar algumas referências à língua atribuída ao outro que, ao longo do filme, acabam funcionando como "legendas" (ou rótulos) de uma maneira de falar e escrever diferente da que deve ser reconhecida como válida no filme.

Nosso interesse em desenvolver um estudo que visasse a observar especificamente esse aspecto nas representações sobre o outro em filmes de Hollywood surgiu em decorrência da onda de discursos produzida por ocasião dos atentados de 11 de setembro de 2001 nos Estados Unidos, visto que, no calor dos acontecimentos, o caráter ficcional do cinema foi exaustivamente explorado nos meios de comunicação, com alguns títulos de filmes sendo incluídos na pauta de inúmeros debates. De lá para cá, a produção literária em torno do acontecimento em si, bem como de aspectos outros que passaram a ser observados a partir do mesmo, tem mantido um ritmo relativamente constante. A visibilidade que se construiu para abordar o episódio, e também os efeitos que a ele sobrevieram no âmbito da política internacional, continuam justificando a produção de artigos, documentários e livros que tentam, cada qual a seu modo, trazer à luz alguma consideração, crítica ou reflexão relevante. Dentre os efeitos do acontecimento, viu-se que, de fato, a apreensão da realidade nunca é direta, mas, como defende o antropólogo Mondher Kilani ${ }^{4}$, “é sempre mediatizada pelas imagens veiculadas pela cultura” (apud AMANCIO, 2000:39). Só é possível nomear determinado acontecimento (um 'ataque terrorista', por exemplo) quando é possível vincular o que ora se vê ao que já se viu ou se experimentou antes. A visão do novo é sempre guiada por um modelo pré-existente, e no caso do 11 de setembro particularmente, conclui-se que a apreensão do horror de suas imagens passava pela experiência adquirida anteriormente no contato com as imagens produzidas pelo cinema.

Este trabalho soma-se, portanto, a tantos outros que elegem o cinema hollywoodiano como objeto de investigação, e ainda que motivado pelo episódio de 2001, não tem o compromisso de tratar do evento isoladamente, mas, antes, de discutir um aspecto da

\footnotetext{
${ }^{4}$ KILANI, M. L'invention de l'autre: Essais sur le discours anthropologique. Lausanne: Payot, 1994, p. 74, apud AMANCIO (op. cit, p. 39).
} 
representação sobre o outro que, a nosso ver, pode ser explorado com mais especificidade. Uma relação mais evidente entre um aspecto do 11 de setembro e aquele que apresentamos no trabalho pode ser observado em uma característica comum entre ambos, isto é, o fato de que, nos dois casos, o outro é representado como um indivíduo desistoricizado, sem vínculos familiares ou afetivos, um corpo silente. Dos acusados de participação no 11 de setembro, pouca informação foi veiculada pela imprensa, do mesmo modo como o outro do filme é negligenciado quanto à sua condição humana.

Há uma vasta literatura de cinema criticando a demonização do outro em Hollywood, observada na freqüente associação do mesmo com a barbárie, mas ainda pouco se discute a questão do tipo de representação que pode deixar à mostra uma modalidade de poder exercida de maneira mais sutil por se situar, por exemplo, no nível da elipse de certos trechos do filme. A crítica, em casos como esse, seria feita menos por aquilo que o filme efetivamente mostra do que por aquilo que escolhe deixar de fora.

O estudo é realizado a partir do pressuposto de que este tipo de representação - o outro como um corpo silente que não fala por si - faz parte da retórica (ou do discurso) colonialista. No caso específico do cinema hollywoodiano, julgamos desnecessário tentar comprovar nesta dissertação seu caráter hegemônico no campo do entretenimento no contexto atual, ainda que não possamos deixar de mencionar que nenhuma condição é estável o suficiente para impedir a emergência de outros tipos de manifestação cultural, como se nota no trabalho de muitos cineastas do chamado “Terceiro Mundo” que reagem contra essa hegemonia. Pois bem, no contexto colonialista cinematográfico, ao colonizado sempre se negará duplamente, como bem observam Stam \& Shohat (1997), o direito ao discurso: “first, in the idiomatic sense of not being allowed to speak, and second in the more radical sense of not being recognized as capable of speech” (p. 192). O tipo de representação sobre o outro que nos propomos a analisar estabelece alguma relação com aquilo que esses autores definem como "the linguistics of domination” (p. 191), noção que pode ser melhor compreendida por meio do estudo detalhado de um corpus que ilustra bem o que os autores teorizam.

Para a análise dessas representações sobre o outro, escolhemos trabalhar com trechos (aqui também tratados como seqüências discursivas) do filme The Siege (Nova York Sitiada, 1998), o qual, dentre outros que também lidam com a questão do terrorismo (como The Delta Force [Comando Delta, 1986], True Lies [1994], Executive Decision [Momento Crítico, 1996], Rules of Engagement [Regras do Jogo, 2000]), apresenta algumas características que o tornaram um objeto de associação mais imediata com o 11 de setembro. Esse filme foi produzido dois anos após o ataque contra as torres Khobar, um alojamento militar norte- 
americano em Dhahran, na Arábia Saudita. Segundo Ferreira (2004), a ação que provocou a morte de dezenove soldados foi atribuída à Al-Qaeda de Osama Bin Laden (p. 16), nome que seria largamente pronunciado três anos depois. Imagens de arquivo mostrando as ruínas das torres e o trabalho de resgate das vítimas são utilizadas nos momentos iniciais do filme (FIGURA 1), demonstrando que a obra também faz parte de uma estratégia de reação política contra uma ação sofrida no mundo real. Tanto o episódio em Dhahran quanto o lançamento do filme ocorreram durante a administração do então presidente Bill Clinton (1993-2000), cuja imagem também é utilizada na seqüência de abertura. De seu lado, o filme aciona a memória do acontecimento de 1996; já o 11 de setembro acionaria também a memória das próprias imagens da obra fictícia. Vale dizer que certas cenas do longa-metragem são as que mais se aproximam de algumas imagens do 11 de setembro, sobretudo porque a história do filme se concentra em Nova York (FIGURA 2). O perfil de um dos acusados da trama (Ali Waziri) também remete ao de Mohammed $\mathrm{Atta}^{5}$, pois Waziri (FIGURA 3), após ter passado pela Alemanha, chega aos Estados Unidos com um passaporte de estudante três dias antes de participar de uma ação terrorista em Nova York. A exposição dessas semelhanças entre fato e ficção não está ligada aos objetivos do trabalho. Ainda que intrigantes do ponto de vista do espetáculo, apenas nos interessam enquanto suporte para a idéia de que há um imaginário sobre o outro (resultado de experiências vividas e outras apenas ilusórias) que sempre determina a produção de sentidos, tanto no cinema como fora dele, e cujas origens só podem ser pensadas quando consideramos um contexto muito mais amplo, como veremos no Capítulo III a propósito da noção de Oriente.
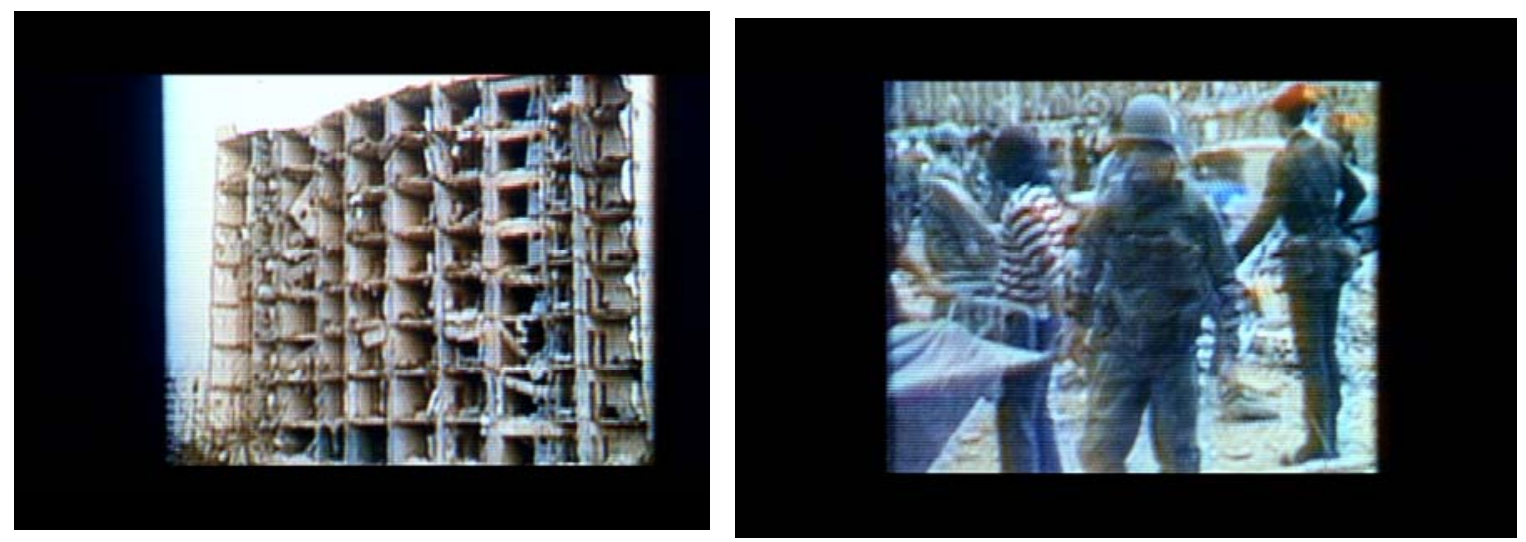

Figura 1: Imagens do atentado de 1996 em Dhahran, Arábia Saudita, exibidas na seqüência de abertura do filme.

\footnotetext{
${ }^{5}$ Um dos palestinos que teria participado do seqüestro do avião da American Airlines (Vôo 11), o primeiro a se chocar contra uma das torres do World Trade Center.
} 
Apesar das semelhanças, o filme procura, na verdade, produzir uma crítica às formas extremas de resolução de conflitos empregados por radicais militares. O próprio título faz alusão àquilo que o discurso liberal do filme condena, uma vez que o estado de lei marcial decretado na cidade para conter o avanço dos ataques inclui o confinamento de centenas de jovens do sexo masculino em um campo de concentração construído na cidade. O personagem Anthony Hubbard (Denzel Washington) defende um tratamento que respeite os direitos civis ao lidar com os acusados de envolvimento nas ações, contrariamente à postura radical e inflexível do general William Devereaux (Bruce Willis), a quem o governo investe de todo o poder necessário para decretar o estado de sítio em Nova York. Segundo o diretor Edward Swick, uma questão que o filme pretende colocar é: até que ponto se pode chegar para conter a violência e assim garantir a liberdade? Fazendo desfilar, portanto, duas posturas políticas, o filme condena a ação discriminatória de Devereaux, que não hesita em usar quaisquer métodos para capturar o inimigo (Make no mistake - we will hunt down the enemy, we will find the enemy, and we will kill the enemy. $)^{6}$. Para o desenvolvimento da ação do filme, o outro é inscrito desde sempre como culpado, portanto já se parte do pressuposto de que seu dizer (quando se fizer necessário para determinada cena) virá despossuído de valor. Essa seria uma das maneiras pelas quais, de acordo com a retórica do discurso colonialista, se representa a aparição do outro como um corpo silente cujo dizer é definido a priori como não válido ou inconveniente. A culpabilidade pré-definida se torna um imperativo para justificar a punição, que pode admitir o extermínio.
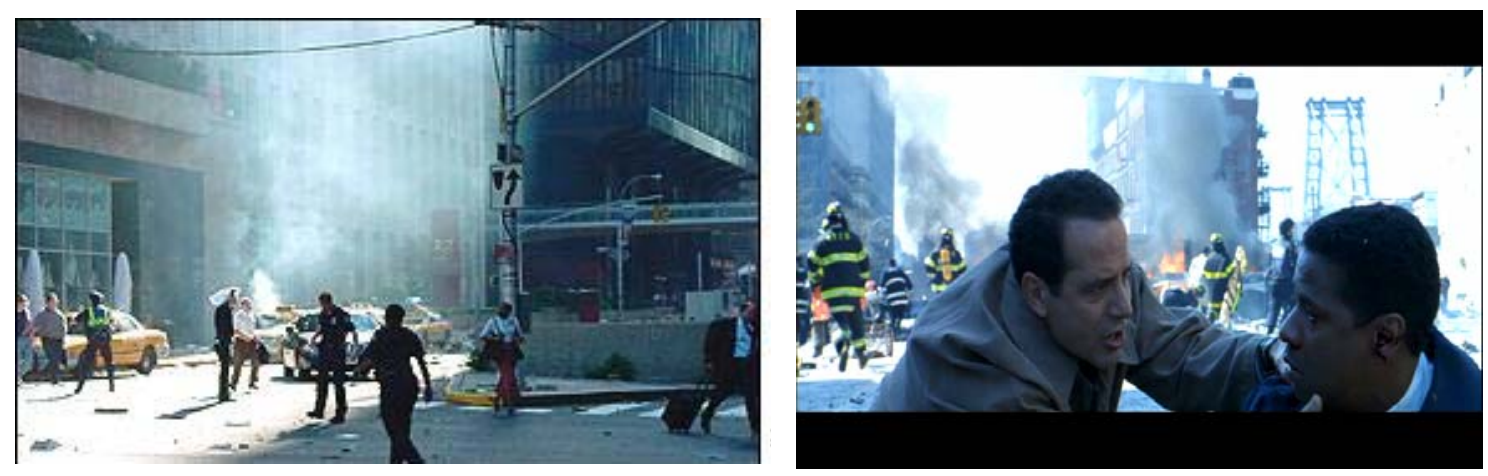

Figura 2: À esquerda, imagem do 11 de setembro; à direita, imagem do filme.

\footnotetext{
${ }^{6}$ Trecho do filme em que o personagem discursa durante uma reunião com as autoridades do governo em Washington para discutir a série de violentos atentados que Nova York passa a sofrer.
} 
Para que possamos melhor conduzir a análise, evitando possíveis distanciamentos do objeto que mais de perto nos mobiliza, formulamos duas perguntas as quais procuraremos responder ao longo do estudo do corpus:

1. Por que mecanismos (considerando a interpelação do indivíduo em sujeito pela ideologia) esse silenciamento do outro acaba aparecendo de maneira espontânea e natural?

2. Que identidades são construídas para cada um dos pólos envolvidos nessas representações, considerando os efeitos de sentido produzidos por e com esse silenciamento?

Acreditamos que o trabalho poderá contribuir no sentido de melhor compreender, em uma situação que podemos hoje classificar como neocolonial, como o discurso dominante não pode prescindir do outro para se (re)afirmar, servindo-se em grande parte de manifestações culturais como o cinema para promover constantemente representações dessa alteridade como corpo silente, incapaz de se representar. Ainda que nos concentremos em um filme hollywoodiano, as constatações resultantes da análise poderão ser aplicadas a outras expressões da cultura contemporânea.
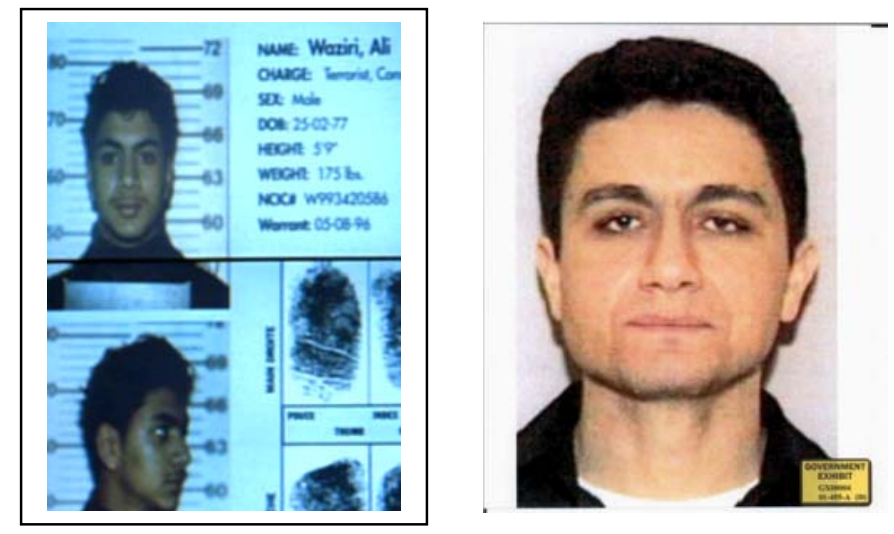

Figura 3: À esquerda, personagem do filme Ali Waziri; à direita, Mohammed Atta.

A versão escolhida para este estudo é a original em inglês, na tentativa de uma maior aproximação das discursividades que mais interessam à investigação. A opção por versões dubladas ou legendadas em outros idiomas inevitavelmente instaurariam novas discursividades. Ressaltamos que não é feita uma análise do filme enquanto obra completa, mas de seqüências discursivas específicas que, no seu conjunto, constituem o recorte necessário para a observação do aspecto que se pretende observar. Transcrevemos as partes dialogadas dessas seqüências e, na maioria dos casos, resumimos cada trecho em questão para melhor situar o leitor em relação ao contexto. Dada a variedade de possibilidades de leitura de 
um objeto fílmico, procuramos, na medida do possível, e sobretudo dependendo do aspecto que se pretende destacar em cada seqüência discursiva, levar em conta na análise a materialidade lingüística, imagética e, em alguns casos, até mesmo os efeitos sonoros. Cientes de que jamais esgotaríamos as possibilidades de leitura, esperamos que o trabalho possa dar ocasião a outros estudos a partir de nossas demonstrações, reflexões e conclusões.

Para a análise do corpus fundamentamo-nos nos pressupostos teóricos da Análise do Discurso de linha francesa (que também abreviamos AD), cujos pressupostos são apresentados no Capítulo I. No Capítulo II, expomos um breve panorama do desenvolvimento do cinema hollywoodiano, abordando o filme The Birth of a Nation (1915) como emblemático do discurso sobre o outro e como fundador da estrutura narrativa clássica hollywoodiana que predomina até os dias atuais. A exposição desse panorama se torna fundamental para entendermos as condições de produção do modo como se apresenta o discurso no tipo de corpus com o qual lidamos. No Capítulo III, para entendermos as condições de produção do discurso que analisamos sobre o outro, aqui encarnado pelo personagem terrorista de origem árabe, apresentamos um panorama de teorizações sobre como o conceito de Oriente se solidificou na cultura hegemônica mundial, principalmente em sua relação com fatos históricos e culturais islâmicos. Esse conhecimento se torna necessário em um trabalho motivado em grande parte pela inquietação do 11 de setembro, visto que o episódio (ou o discurso construído a partir dele) é freqüentemente associado a questões ligadas a crença, as quais costumam estar presentes em filmes que abordam o terrorismo. No Capítulo IV, passamos para a análise do corpus, dividindo-a em três seções. Começamos analisando a seqüência de abertura do filme, a qual já introduz elementos significativos que confirmam a hipótese central do trabalho acerca do investimento no silenciamento do dizer da alteridade na narrativa; em seguida são analisadas quatro seqüências discursivas nas quais procuramos demonstrar como se representa a ininteligibilidade do dizer atribuído ao outro em situações de interação com personagens principais; por fim, analisamos momentos diferentes em que são feitas referências à própria língua do outro, tanto de maneira direta, com a nomeação da mesma nas falas, quanto mais subliminarmente, por meio da exibição de caracteres em planos inferiores da cena. 


\section{CAPÍTULO I - A abordagem discursiva do texto}

\section{1 - Apresentação}

Iniciamos este capítulo com uma breve exposição dos princípios básicos da Análise do Discurso de linha francesa. Optamos por torná-la breve neste momento introdutório, visto que expandiremos pontos mais específicos ao longo da análise. Em seguida, procuramos mostrar a aplicabilidade da $\mathrm{AD}$ no estudo de um corpus que não se restringe à linguagem verbal. Aqui também tratamos da questão da identidade, um aspecto com o qual uma leitura discursiva freqüentemente está vinculada, e concluimos o capítulo com uma abordagem do conceito de “representação”, sobretudo enfatizando o modo como o termo, bastante presente ao longo do texto desta dissertação, é concebido em uma análise com perspectiva discursiva.

\section{2 - A Análise do Discurso (AD) francesa}

A partir da leitura de Louis Althusser, em sua obra "Ideologia e Aparelhos Ideológicos de Estado”, e de conceitos de Michel Foucault na “Arqueologia do Saber”, Michel Pêcheux, considerado o fundador da Análise do Discurso, extraiu os conceitos de formação ideológica do primeiro autor e de formação discursiva do segundo. Surgida da propagação de um quadro teórico que aliava o lingüístico ao sócio-histórico, a Análise do Discurso possui como conceitos centrais, além de ideologia e discurso, a questão do sujeito, o qual não é concebido como origem do sentido ou causa de si, como um dado a priori, mas constituído do discurso, produzido por um processo de interpelação-identificação. Segundo Pêcheux (1988), “os indivíduos são 'interpelados’ em sujeitos-falantes (em sujeitos de seu discurso) pelas formações discursivas que representam 'na linguagem' as formações ideológicas que lhes são correspondentes” (p. 161). Com isso, Pêcheux está discordando de Saussure quanto à dicotomia língua/fala, uma vez que essa separação autoriza a reaparição da noção do conceito de sujeito livre da filosofia, senhor de seu discurso, que poderia afirmar, por exemplo, que ele é quem é, com seu nome, suas idéias e suas intenções. Orlandi (1988), em sua leitura do autor, irá resumir bem a noção de sujeito conforme é entendido no domínio da Análise do Discurso, destacando o efeito de evidência que a ideologia produz e que mascara esse processo de identificação pela norma: 
A evidência do sujeito, ou melhor, sua identidade, esconde que esta resulta de uma identificação, que é o que constitui sua interpelação. Essa interpelação - que se dá pela ideologia - produz o sujeito sob a forma de sujeito de direito (jurídico) que, historicamente, corresponde à forma-sujeito do capitalismo: sujeito ao mesmo tempo autônomo (e, logo, responsável) e determinado por condições externas (p. 57).

Diante do exposto, outra questão que também se torna crucial em $\mathrm{AD}$ é a da materialidade do sentido, uma vez que se pode então dizer que este não "nasce" no sujeito, mas é construído historicamente. A aparente evidência das palavras e dos enunciados que o sujeito falante produz é resultado da ideologia, não concebida como um conjunto de idéias, mas como “força material”. Empregando termos específicos de Pêcheux, essa ilusão de evidência é fornecida pelo “todo complexo das formações ideológicas” (op. cit., p. 160). O autor esclarece a expressão argumentando que os sentidos das palavras, expressões e proposições, por exemplo, não existem em si mesmos, mas são determinados pelas posições ideológicas em jogo no processo sócio-histórico no qual aquelas são (re)produzidas. Isso equivale a dizer que "as palavras, expressões, proposições, etc., mudam de sentido segundo as posições sustentadas por aqueles que as empregam” (ibidem, p. 160). Tomando como exemplo expressões extraídas de nosso corpus que fazem referência ao outro como Arabspeaking, nota-se que o seu sentido dentro de uma proposição do sujeito falante personagem não existe, conforme diria Pêcheux, "em sua relação transparente com a literalidade do significante” (p. 160), qual seja, o fato isolado de que alguém na trama fala uma língua chamada árabe, mas essas palavras adquirem sentido em referência às formações ideológicas em que essas posições se inscrevem. Aquilo que se diz e se mostra em um filme é determinado por uma formação discursiva que determina o que pode e deve ser dito (e mostrado, como podemos acrescentar). A formação discursiva, entendida como o "conjunto de enunciados marcados pelas mesmas regularidades, pelas mesmas 'regras de formação'”, determina portanto aquilo que o sujeito pode e deve dizer a partir de um lugar social historicamente determinado (BRANDÃO, 2004:106-107). O sentido da palavra composta Arab-speaking em uma formação discursiva diferente da que se observa no filme sobre terrorismo seria outro, por exemplo, caso as mesmas fossem proferidas em um filme sobre as mil e uma noites, ainda que dentro de uma mesma formação ideológica, esta entendida como um conjunto complexo de representações que dizem respeito a uma posição dada em uma conjuntura sócio-histórica dada. 


\section{3 - A AD como dispositivo de análise fílmica e a questão da identificação}

A leitura realizada sob a ótica da AD se caracteriza por um processo inicial de desuperficialização do material bruto selecionado para análise em que obrigatoriamente são considerados os aspectos relacionados ao "como se diz [...] quem diz, em que circunstâncias" (ORLANDI, 2002:65). Há uma passagem inicial da superfície lingüística (ou imagética, no caso de um corpus fílmico) para o objeto discursivo já previamente definido pelo analista em um tratamento inicial do corpus. Em um primeiro momento, procura-se desnaturalizar a relação palavra-coisa (ou imagem-coisa), desfazendo a ilusão de que "aquilo que foi dito [ou mostrado] só poderia sê-lo daquela maneira” (ORLANDI, 2002:77) (acréscimo nosso). Não se consideram supostas intenções do indivíduo (o roteirista ou diretor de um filme, por exemplo), pois parte-se de uma concepção de sujeito não idealista e não entendido como origem de seu discurso, consciente e intencional. O fato de que a ideologia é a "condição para a constituição do sujeito e dos sentidos” (ORLANDI, 2002:46) coloca-nos diante do papel fundamental da interpretação. Em sua relação com o mundo o sujeito é constantemente levado a interpretar, perguntando-se o que isto ou aquilo quer dizer, ainda que sem se dar conta desse movimento de interpretação que faz com que o sentido apareça como "evidência, como se ele estivesse já sempre lá” (op. cit. 2002:46). Considerando a produção de um filme, sempre haverá, tanto no ato de escrever, dirigir ou editar, objetos simbólicos necessariamente sendo interpretados, e o trabalho do analista passa a ser o de problematizar a ilusão de transparência de sentidos que, como vimos, resulta desse movimento de interpretação, já que o filme, segundo Dayan (1984), não pode expor a operação ideológica, seu funcionamento e sua mecânica; é necessário que as oculte, "naturalizando" seu funcionamento e suas mensagens de algum modo. Embora a concepção de ideologia desse autor não se enquadre exatamente nos termos da $\mathrm{AD}$, uma vez que parece sugerir que o sujeito possui, o tempo todo, controle daquilo que produz discursivamente, podemos também observar em sua reflexão a preocupação em demonstrar o investimento do cinema não em constituir um retrato de uma dada realidade (algo impossível, como se sabe), mas em mascarar o trabalho de manipulação ideológica por trás dessas representações. Segundo o autor:

The message must appear to be complete in itself, coherent and readable entirely on its own terms. In order to do this, the filmic message must account within itself for those elements of the code which it seeks to hide - changes of shot and, above all, what lies behind these changes, the questions "Who is viewing this?" and "Who is ordering 
these images?” [...] In this way, the viewer's attention will be restricted to the message itself and the codes will not be noticed (p. 447).

Por “mensagem”, entendemos especificamente um dos pontos considerados durante o trabalho de planejamento que precede a produção de qualquer filme. As condições de produção e o contexto histórico são aqui determinantes, independentemente do gênero em questão. Assim, tanto na despretensiosa fábula em desenho animado de Aladdin (1992) como no filme documentário Schindler's List (1993), há aspectos motivando sua produção que não podem aparecer. Em ambos os casos temos a presença do discurso, o qual não tem como função constituir, como esclarece Vignaux ${ }^{7}$ (1979), a representação fiel de uma determinada realidade; o discurso funciona, sim, no sentido de assegurar a permanência de um certo tipo de representação, e no caso dos filmes aqui citados não importa que a mesma esteja associada a uma obra reconhecidamente ficcional ou a uma de caráter documental. Nesse aspecto, a AD difere de outras abordagens da ideologia, pois não busca investigar as supostas intenções do indivíduo por trás dessas representações, mas tenta compreender como e por que as mesmas são veiculadas em determinado momento histórico e o que determinaria as palavras e as imagens ali utilizadas. Como já foi exposto, o conceito de ideologia que se privilegia em AD não se resume a um conjunto de idéias com uma existência ideal e espiritual; antes, sua existência é sempre material, e o que a caracteriza é, segundo Pêcheux (apud ORLANDI, 2002:46), a dissimulação de sua existência no interior de seu próprio funcionamento, o que faz com que se produzam evidências subjetivas.

A análise das representações sobre o outro no filme coloca-nos diante da questão da construção de identidade, pois a imagem daquele que comanda essas representações é também construída no momento em que inscreve a alteridade no fio de seu discurso. Isso também se deve pelo fato de que as identidades, como afirma Grigoletto (2006), “se constituem no espaço da diferença: o outro como aquilo que eu não sou, no meu imaginário, mas sem o qual eu não existo” (p. 16). Nos trechos do filme que compõem nosso corpus há freqüente repetição e retomada de outros dizeres, os quais acabam assegurando a manutenção de determinadas identidades. De um lado, aquela que se coloca como " $x$ ”; de outro, aquela que se opõe a “x”. Esse fenômeno de construção de identidades por meio da repetição se dá porque, como sugere Orlandi (1990):

\footnotetext{
${ }^{7}$ Referência a seu artigo “Argumentation et discours de la norme”. IN: Langages, no. 53, 1979, pp. 67-86.
} 
[F]alar sobre o “outro” para instituir a imagem de “si”, cria sua tradição (sou-semprejá), além de sua imagem (como deve ser). O pré-construído (o já-dito) em seu retorno produz a inter-compreensão (desconstrução do 'outro') num movimento de concentração de sentidos (p. 44).

Esse constante movimento que visa a reafirmar uma visão de mundo e a perpetuar uma determinada identidade já sinaliza para o seu aspecto móvel, incerto, embora se invista constantemente em justamente mostrar que ela é definida, estável, fixa. Não é, e o que se tem constatado cada vez mais é que a identidade se caracteriza justamente por seu caráter cambiante, provisório e até problemático quando se depara, por exemplo, com o que se costuma chamar de crise de identidade. Hall (2005), servindo-se da observação do crítico cultural Kobena Mercer $^{8}$, lembra que isso se torna um problema quando "algo que se supõe como fixo, coerente e estável é deslocado pela experiência da dúvida e da incerteza” (p. 9). Não se trata de uma "crise" de que o sujeito esteja sofrendo com o colapso de identidades, mas do fato de que este passou a ser composto de várias identidades, descentradas.

A noção do caráter cambiante da identidade no presente trabalho é fundamental, uma vez que a Análise do Discurso incorporou, como esclarece Carmagnani (2003), a visão também defendida pela psicanálise de um “sujeito cindido, heterogêneo, perpassado pelo inconsciente, habitado por desejos recalcados que irrompem via simbólico, pela linguagem onírica e verbal” (p. 307). A autora está também se baseando nesta afirmação de Hall (2005) que dá sustentação a uma abordagem da identidade pelo viés da psicanálise:

\begin{abstract}
Dentro de nós há identidades contraditórias, empurrando em diferentes direções, de tal modo que nossas identificações [e não identidades, que supõem algo fixo] estão sendo continuamente deslocadas. Se sentimos que temos uma identidade unificada desde o nascimento até a morte é apenas porque construímos uma cômoda estória sobre nós mesmos ou uma confortadora "narrativa do eu”. A identidade plenamente unificada, completa, segura e coerente é uma fantasia (p. 13) (acréscimo nosso).
\end{abstract}

Esse conceito de identidade é relevante ao trabalho também se observarmos como, ao longo da história do cinema hollywoodiano, no ponto que interessa ao estudo, o outro enquanto antítese dos valores norte-americanos já assumiu diferentes configurações, como

\footnotetext{
${ }^{8}$ MERCER, K. Welcome to the jungle. IN: RUTHERFORD, J. (org.). Identity. Londres: Lawrence and Wishart, 1990, p. 43, apud HALL (op. cit, p. 9).
} 
afirma Alcino Leite Neto ${ }^{9}$, “em decorrência do estágio de produção da identidade americana, das paranóias sociais e das necessidades de propaganda política transferidas a Hollywood”. Isso se explica pelo fato de que o cinema, por sua vez, "responde também aos anseios coletivos de uma sociedade que compartilha características e sofre as influências desse[s] novo[s] contexto[s]” (GOROVITZ, 2006:28) (acréscimos nossos).

Nota-se portanto que a base do processo identitário é existir sempre em relação a uma alteridade - "to exist is to be called into being in relation to an otherness, its look or locus", como afirma Bhabha (1994:44) a partir da leitura psicopolítica de Frantz Fanon. Em tempos atuais, isso também ocorre por meio da materialização da ideologia em produtos culturais por meio dos quais é possível notar o fenômeno da constante dependência da figura do outro na compreensão de si, como é o caso da construção de identidades que o filme The Siege possibilita observar. Pensando justamente nessa questão que o filme suscita com as representações sobre o outro como um corpo silente, notamos, com um primeiro olhar lançado sobre o corpus, que o "eu” afirma sua existência como detentor do papel de porta-voz de grupos para os quais as oportunidades de se representar em um contexto mais amplo são limitadas ou mesmo inexistentes a partir das características que atribui ao outro como avesso à comunicação.

\section{4 - A representação como construção}

O termo “representação” já sugere um movimento que toma um objeto como ponto de referência (a re-apresentação de algo que existe), mas é necessário definir o sentido com que o termo é empregado ao longo deste trabalho. O conceito de representação encontrado na maioria dos dicionários remete normalmente à idéia de substituição - ou seja, à possibilidade de que algum signo ou símbolo cumpra o papel de re-apresentar alguma coisa. Assim, a imagem de uma pomba (foto ou ilustração), a qual já constitui uma representação da referida ave enquanto ser do mundo real, pode representar um conceito abstrato como a paz, do mesmo modo que uma estátua pode representar alguma figura humana da história. Segundo essa maneira de pensar a representação, uma imagem passa a ser o representante ou o substituto “de qualquer coisa que ela não é e que não está presente” (NOVAES, 2005:20). O

\footnotetext{
${ }^{9}$ Autor do artigo "Hollywood busca seus novos vilões”. Folha Online, Pensata. http:/www1.folha.uol.com.br/folha/pensata/ult682u42.shtml, consultado em 09-06-2008).
} 
autor afirma que representamos aquilo que não pode estar presente, através de uma imagem que, por sua vez, não é a “coisa”, e sim uma relação com uma outra coisa, ou a "representação de uma coisa ausente, que reproduz certos aspectos da aparência visível” (p. 21). Novaes ainda se serve de uma explicação de Platão ${ }^{10}$ para mostrar que a imagem, para representar, “não deve ter todas as características da coisa, mas apenas algumas” para concluir que "para melhor representar é preciso não se assemelhar tanto” (ibidem). O autor prosseguirá com outros exemplos, mas o que interessa observar nessa sua exposição da representação é a proximidade que fica pressuposta entre o objeto representado e a própria representação, como se pudéssemos elevar a representação à categoria de imitação.

Evidentemente não é dessa maneira que nos apropriamos do termo representação para a realização de nosso estudo, mas interessa expor como o termo é mais comumente percebido, sobretudo quando consideramos o advento da mecanização da imagem. A propósito dessa mecanização, Novaes (op. cit) dirá que "há uma infinidade de imagens absolutamente idênticas da mesma realidade” (p. 22). Compreendemos que o autor está aqui se referindo à qualidade das imagens que são produzidas atualmente com o crescente avanço tecnológico nesse campo, porém essa maneira de conceber a representação pode, sob uma outra perspectiva, nos autorizar a afirmar, apenas para nos situar no domínio de nosso estudo, que um filme documentário que se propusesse a re-apresentar um determinado objeto (violência em uma comunidade, por exemplo) devesse ser reconhecido como retrato fiel daquela realidade. Não estariam sendo levados em conta fatores ideológicos que entram inevitavelmente nesse processo que envolve construção, tanto da parte do produtor da imagem quanto do espectador. O espectador ou leitor de um filme, uma imagem estática, assim como o leitor de um texto, também são instâncias de construção de sentido, por via da interpretação que fazem daquilo que vêem ou lêem. Servindo-nos ainda do exemplo do filme documentário (e insistimos nesse gênero apenas porque se costuma pensar na divisão ficção-realidade), por mais verossímil que seus produtores procurassem torná-lo, aproximando-se do objeto do mundo real com o uso de imagens autênticas e depoimentos de habitantes do lugar, será produzido (ou construído) a partir de escolhas que revelarão um sujeito ideológico, constituído socialmente. Isso poderá ser constatado, entre outros aspectos, na escolha do ângulo para determinada cena, na seleção e organização dos trechos que ocorrem na fase de

\footnotetext{
${ }^{10}$ O autor se refere ao trecho do diálogo “Crátilo” (em ‘Diálogos’) no qual Platão pergunta se, caso alguma divindade reproduzisse Crátilo tal qual ele é no exterior e interior, o resultado seria um Crátilo e uma imagem de Crátilo, ou dois Crátilos?
} 
edição do filme e na escolha da trilha sonora que possa provocar determinado efeito em uma cena.

Outra abordagem de representação pode ser encontrada em Nichols (1981), autor que reconhece a importância da simbolização na intercomunicação quando lembra que há símbolos que cumprem papéis fundamentais nos processos de comunicação, como no caso do pronome "eu”, utilizado, por exemplo, no encontro verbal de dois interlocutores, já que ambos se servem do mesmo símbolo para se referir a si. No entanto, reconhece também que a ideologia emerge na sua associação com esses mesmos processos de comunicação. Segundo o autor, "ideology involves the reproduction of the existing relations of production (those activities by which a society guarantees its own survival)” (ibidem). Exemplificando, é por meio da imagem de nosso corpo físico em uma fotografia que, muitas vezes, nos representamos, bastando que nos lembremos dos documentos por meio dos quais garantimos nossa existência e nos defendemos perante a lei. No entanto, a ideologia poderá funcionar no sentido de determinar lugares fixos para que ocupemos na sociedade com base nesses mesmos processos de comunicação. É o que entendemos a partir da seguinte afirmação de Nichols:

Ideology operates as a constraint, limiting us to certain places or positions within these processes of communication and exchange. [...] it is the image a society gives of itself in order to perpetuate itself. These representations serve to constrain us (necessarily!); they establish fixed places for us to occupy that work to guarantee coherent social actions over time. Ideology uses the fabrication of images and the processes of representation to persuade us that how things are is how they ought to be and that the place provided for us is the place we ought to have (p. 1).

São infinitas as possibilidades de se re-apresentar um objeto, como se sabe, mas o que queremos enfatizar em relação a esse fenômeno se baseia também em um dos pressupostos da Análise do Discurso segundo o qual “não há sentido sem interpretação e, além disso, diante de qualquer objeto simbólico, o homem é levado a interpretar, colocando-se diante da questão: o que isto quer dizer?” (ORLANDI, 2002:45). Se o modo como percebemos um objeto está condicionado à interpretação (o sentido não é fornecido a priori), toda representação levará a marca do sujeito.

Hall (1997) também reconhece que a representação é uma parte fundamental do processo pelo qual "meaning is produced and exchanged between members of a culture" (p. 15) e que envolve o uso de linguagem, signos e imagens para representar as coisas, mas 
admite que seu conceito não pode ser reduzido a algo tão simples. Das três teorias da representação que apresenta - reflective or mimetic approach, intentional approach e constructionist approach (pp. 24-25) - queremos destacar a terceira, pois é a que mais se aplica para o tipo de abordagem com que lidamos com o corpus. Resumidamente, na primeira teoria, o sentido estaria no próprio objeto, pessoa, idéia ou evento do mundo real, e a linguagem funcionaria, no caso, como um espelho; na segunda, é o próprio falante ou autor que impõe seu sentido no mundo através da linguagem, isto é, as palavras significam aquilo que seu autor deseja que signifiquem (tradução nossa). A terceira abordagem, diferentemente das anteriores, reconhece que nem as coisas por si mesmas nem os usuários individuais da linguagem podem determinar e fixar o sentido. De acordo com essa abordagem construcionista:

Things don't mean: we construct meaning, using representational systems - concepts and signs. Hence it is called the constructivist or constructionist approach to meaning in language. According to this approach, we must not confuse the material world, where things and people exist, and the symbolic practices and processes through which representation, meaning and language operate. Constructivists do not deny the existence of the material world. However, it is not the material world which conveys meaning: it is the language system or whatever system we are using to represent our concepts. It is social actors who use the conceptual systems of their culture and the linguistic and other representational systems to construct meaning, to make the world meaningful and to communicate about that world meaningfully to others (p. 25) (grifos do autor).

Queremos concluir este capítulo lembrando também que o fato de que uma representação, independentemente da abordagem, não é aqui entendida como equivalente da realidade, não significa que ela seja percebida como construção. A ideologia funciona justamente no sentido de torná-la atraente para que possamos reconhecer alguma verdade que ela não contém. 


\section{CAPÍTULO II - Desenvolvimento do cinema hollywoodiano}

\section{1 - O nickleodeon e a representação sobre o outro}

Em tempos atuais, uma seqüência de pequenas imagens se movimentando contra um fundo manchado no interior de um tipo de caixa que era chamado de penny arcade certamente não atrairia a atenção de quem convive com grande variedade de imagem que se movimenta. Quem tivesse acesso a tal engenhoca podia ver nada mais que simples cenas cômicas, como as de uma pessoa espirrando. Essa invenção de Thomas Alva Edison por volta de 1896 era uma espécie de peep show, isto é, uma exibição de imagens que se oferecia a quem aproximasse o olho de uma abertura na caixa. O valor cobrado para assistir aquelas imagens era de cinco cents americanos, que correspondem a um nickel, de onde derivou o nome nickleodeon que, por sua vez, se referia aos locais onde as pessoas tinham acesso à nova modalidade de imagem. Thomas Edison teria rapidamente perdido o interesse por aquilo que considerava apenas um brinquedo, o que, no entanto, não impediu que outros se ocupassem de desenvolver a engenhoca e passassem a projetar as imagens em uma tela, possibilitando que essas fossem então apreciadas por grupos de espectadores, e não apenas individualmente. Por volta de 1905, mais de 5.000 nickleodeons, instalados em armazéns devidamente adaptados, já exibiam seus filmes a quem se dispusesse a pagar cinco cents pelo ingresso (HOFSTADTER et al, 1976:551).

Se, inicialmente, os peep shows exibiam apenas cenas demasiadamente ingênuas para os padrões atuais, os filmes que foram criados à medida que o aparelho se modernizava iam se tornando mais elaborados, incluindo, por exemplo, cenas de cowboys e xerifes perseguindo bandidos. Também era possível assistir aos hoje tradicionais pastelões, ou cenas cômicas de pessoas escorregando em casca de banana ou caindo em bueiros. Por mais rudimentares que possam parecer ao espectador da atualidade, as imagens do cinema primitivo nos mostram um campo de representação muito definido em relação à sociedade e os costumes da época. Por trás das figuras do cowboy e do xerife, por exemplo, podemos observar a preocupação com a disciplina, a autoridade e o risco da punição. Em uma época em que o cinema ocupava o lugar hoje preenchido pela televisão para as grandes massas, os filmes serviam não apenas para entretê-las, mas também para reforçar os valores americanos tanto para a população nativa espalhada pelo país quanto para “as levas de imigrantes ignorantes do inglês que podiam 'ler' 
nas imagens as regras morais e políticas do país para onde tinham mudado ${ }^{11 ” . ~ E s s e ~ p a p e l ~}$ disciplinador do cinema já em sua fundação está em conformidade com o que afirma Foucault (1997) sobre a produção do discurso em todas as sociedades; para o autor, essa produção “é ao mesmo tempo controlada, seleccionada (sic), organizada e redistribuída por procedimentos que têm por função esconjurar os seus poderes e perigos [...] esquivar a sua pesada e temível materialidade” (pp 9-10). Em cada época determina-se aquilo que pode ser dito com o objetivo de internalizar regras de conduta e de exclusão daqueles que se indispõem a cumprilas.

O que essas representações dos nickleodeons também revelam é a importância do substrato narrativo da figura antagônica na história que o filme se propõe a contar - ou seja, da alteridade - e aqui observamos que sempre se trabalha no sentido de promover um certo engajamento por parte do espectador, levando-o a se identificar com a mensagem que a história pretende transmitir, já considerando aqui o caráter ideológico. Todos os esforços são feitos para que o espectador não assuma a imagem do outro da história, mas que adote do personagem que é celebrado não somente seu ponto de vista, mas também suas emoções.

Até 1903 não é possível afirmar a existência de filmes como hoje conhecemos, isto é, estruturados dentro de uma narrativa cinematográfica que possibilita ao espectador perceber que ali existe uma trama, uma história com início, meio e fim. O primeiro filme com uma trama reconhecível (The great train robbery) foi realizado nesse ano e seu êxito imediato estimulou todos os produtores da época a também investirem no desenvolvimento de filmes de suspense. Todavia, esse filme ainda não continha os elementos que deveriam determinar a estrutura de um filme hollywoodiano. Isso só ocorreria cerca de uma década mais tarde.

\section{2 - A instalação da estrutura clássica hollywoodiana}

A forma de narrativa clássica do cinema hollywoodiano só foi inaugurada a partir de 1915. Os filmes feitos antes desse período, embora já elaborados em comparação com as primeiras experiências desde a invenção do aparelho que dava movimento às imagens, eram muito rudimentares, fragmentados e carentes ainda de uma continuidade narrativa. É verdade que, a rigor, não se pode afirmar que nas produções primitivas anteriores a 1915 inexistia

\footnotetext{
${ }^{11}$ Essas informações também são baseadas no artigo de Alcino Leite Neto (Hollywood busca seus novos vilões), publicado na Folha Online, Pensata (http:/www1.folha.uol.com.br/folha/pensata/ult682u42.shtml).
} 
qualquer tipo de narração, pois todo o processo, envolvendo desde a escolha do objeto (ainda que fosse apenas alguém espirrando) até sua exibição, passa pela interpelação do indivíduo em sujeito, do modo como entende a $\mathrm{AD}$ - ou seja, sempre há escolhas, como a seleção do melhor ângulo, melhor pessoa para o papel. Todavia, o conceito de narração que agora passamos a considerar, em um primeiro momento, é o de uma estrutura mais elaborada que contenha início, meio e fim, não significando que essas etapas sejam sempre facilmente identificáveis. Ainda assim, elas costumam estar presentes em toda narração, de um modo ou de outro. A esse respeito Christian Metz (1977) esclarece que:

Embora seja verdade que alguns tipos de narração, culturalmente muito elaboradas, têm a característica de trapacear com o final (conclusões 'suspensas' ou evasivas, construções em abismo nas quais o final do acontecimento-narrado explicita e estabelece as condições em que aparece a instância-narradora, desenlaces em forma de parafuso-sem-fim etc.), trata-se apenas de elaborações secundárias que enriquecem a narração sem destruí-la, e que não são capazes de, nem desejam, fazer com que ela escape à sua exigência fundamental de fechamento (pp. 30-31).

Essa constatação acerca do aspecto de “fechamento” da narração pode apresentar um problema, quanto à produção do filme, que está relacionado ao desejo de completude. O tempo disponível para que a idéia de um filme seja passada é de aproximadamente duas horas (duração média de um longa-metragem), e é neste ponto que a questão colocada pelo trabalho sobre a destinação de espaço para o dizer pode também convidar a outras reflexões. Em termos práticos e até simplistas, esse tempo não seria suficiente para dar conta daquilo que muitos críticos observam nos filmes como uma lacuna (aqui pensando a desistoricização de um personagem em uma história) que acaba criando problemas de redução de certos grupos a aspectos isolados de sua cultura. Não que o sujeito que comanda essas representações seja plenamente "historicizado" dentro da economia da narrativa fílmica, mas como este tem a posse da palavra e detém o ponto de vista na maior parte do tempo, ampliam-se as chances de que o espectador possa se identificar com algum aspecto de caráter histórico do mesmo. Em dado momento de "Nova York Sitiada”, o personagem Anthony Hubbard (Denzel Washington) ouve parte de "sua história” narrada, em tom irônico, pela agente da CIA vivida por Anette Benning, que teria investigado o passado daquele. Ainda que resumidamente, diz o que sabe sobre ele: que estudou em uma escola católica no bairro do Bronx, foi "president of this, captain of that, hard work, make a difference, fair play, change the system from within”- 
ou seja, mesmo em uma conversa momentaneamente distanciada das tensões do filme, há um elemento de historicização que inexiste quando da inscrição do outro.

No cinema, não se trata apenas de "falar muito" durante a narrativa, pois outros elementos podem perfeitamente funcionar como aliados no movimento de privilegiar um certo ponto de vista e de rebaixar ou silenciar um outro. Vanoye e Goliot-Lété (2005) relacionam os seguintes princípios que passaram a ser obedecidos após a instalação da continuidade narrativa no cinema hollywoodiano:

- homogeneização do significante visual (cenários, iluminação) e do significado narrativo (relações legendas/imagens, desempenho dos atores, unidade do roteiro: história, perfil dramático, tonalidade de conjunto), depois do significante audiovisual (sincronismo da imagem e dos sons - palavras, ruídos, música);

- linearização, pelo modo como se vincula um plano ao plano seguinte: vínculo no movimento (no gesto de um personagem ou no movimento de um veículo), vínculo no olhar (um personagem olha / enxergamos o que ele enxerga), vínculo no som (existe até nos filmes ditos mudos: um personagem ouve / vemos o que ele ouve; ou melhor, num filme sonoro, ouve-se um ruído em um plano; identifica-se sua fonte no plano seguinte) (pp. 25-26).

Muitos dos elementos acima já podem ser encontrados no filme do diretor norteamericano David W. Griffith que, segundo a maioria dos especialistas, continua sendo considerado um marco na história do cinema mundial por reunir em sua produção inúmeros aspectos técnicos inovadores para a época. Com The birth of a nation (1915), com duração aproximada de três horas, Griffith conseguiu desobrigar a câmera de cinema dos temas típicos dos nickleodeons e das limitações dos cenários de estúdio. As inovações técnicas a ele atribuídas nesse filme incluem, por exemplo, amplos panoramas do pelotão de soldados do exército, fade-outs e close-ups ${ }^{12}$ dos protagonistas, entre outros efeitos que revelam o escopo e a flexibilidade da câmera e da tela (HOFSTADTER et al., 1976:552). A Griffith também se atribui o mérito de ter incorporado figuras de montagem que muito contribuíram para estruturar a narrativa clássica hollywoodiana, como a montagem alternada, que permite o desenvolvimento simultâneo de dois ou mais eventos e, ainda segundo Vanoye e Goliot-Lété (2005), a técnica do insert, um primeiro plano de detalhe que, em uma cena, informa algo

\footnotetext{
${ }^{12}$ Fade out é o desaparecimento gradativo de uma imagem; close-up (ou primeiro plano) é a cena fechada de um objeto, normalmente mostrando a cabeça inteira do personagem, do colarinho ou gola para cima.
} 
essencial ao espectador ao mesmo tempo em que reforça seu impacto dramático, como por exemplo a exibição do plano de um revólver (p. 26). Por essas características, Xavier (2005) também sustenta com certa veemência que Griffith foi “o primeiro grande sistematizador, o modelo a ser seguido pelos cineastas” (p. 36).

O que caracteriza a narrativa clássica, pelo que se pode depreender a partir da preocupação do produtor do filme em proporcionar ao espectador o maior número possível de elementos para que o mesmo possa acompanhar a narrativa, é que as técnicas cinematográficas utilizadas devem garantir, em seu conjunto, coerência, clareza e linearidade a esse ato de narrar. De modo geral, na narrativa clássica, “o encadeamento das cenas e das seqüências se desenvolve de acordo com uma dinâmica de causas e efeitos clara e progressiva” (Vanoye e Goliot-Létè, 2005:27). Importa acrescentar, ainda segundo esses autores, que até mesmo o star system, método de criar e promover astros de cinema em Hollywood, funciona como reforço da característica da narrativa clássica de centrar-se normalmente em um personagem principal (ibidem). Podemos compreender melhor como isso funciona, em termos práticos, se observarmos como determinados astros costumam ser explorados por Hollywood em segmentos específicos. É o caso, por exemplo, de Sylvester Stallone na série Rambo, Bruce Willis em Die Hard (Duro de matar), Arnold Schwarzenegger em Terminator (O exterminador do futuro) e Harrison Ford em Indiana Jones. Em comum, possuem características como pele clara, compleição forte típica de herói idealizado, além do fato de serem do sexo masculino. O cinema clássico hollywoodiano também se caracteriza, portanto, por uma certa previsibilidade - ou seja, o espectador sabe desde o início que a figura principal do herói triunfará no final.

Podendo abordar os mais variados assuntos, pode-se dizer que não há um tema importante do qual algum filme hollywoodiano ainda não tenha se ocupado ao longo da história dessa indústria. A retratação de assuntos diferentes como dramas familiares, relacionamentos amorosos, guerras, fenômenos da natureza, conflitos políticos, entre tantos outros, apresentará, é verdade, as peculiaridades do gênero, porém sempre vai repetir as características do filme clássico hollywoodiano: começo, meio, fim e uma mensagem facilmente reconhecível pelo espectador. 


\section{3 - O discurso sobre o outro em The birth of a nation}

O filme The birth of a nation, da fase do cinema mudo, pode ser considerado uma das mais conhecidas e polêmicas produções na cinematografia hollywoodiana. Sua trama, dividida em duas partes, gira em torno da Guerra Civil e da Reconstrução nos Estados Unidos. Seu caráter polêmico, especialmente para um espectador da atualidade, pode ser constatado já a partir do cartaz de promoção da obra (FIGURA 4) mostrando um membro da organização $\mathrm{Ku}$ Klux Klan ${ }^{13}$ montado em um cavalo em um típico gesto de quem luta por uma causa. A popularidade do filme se deve portanto não apenas às inovações técnicas que o diretor David W. Griffith introduziu, mas também pela abordagem racista que faz com que a maior parte dos comentários acerca da obra reserve sempre um espaço para contemplar sua negatividade: "probably the most racist major movie of all time” (LOEWEN, 1995:18); “a partisan and intolerant film” (HOFSTADTER et al, 1976:552). Embora o filme tenha recebido inúmeras críticas já na época de seu lançamento, poderíamos argumentar que, em tempos atuais, com as preocupações relativas à valorização de atitudes politicamente corretas, um trecho falado ou escrito que ousasse afirmar que "the white men were roused by a mere instinct of selfpreservation... until at last there had sprung into existence a great Ku Klux Klan, a veritable empire of the South, to protect the Southern country” seria provavelmente censurado, uma vez que celebra uma organização caracterizada por ideologias que se opõem fundamentalmente aos direitos humanos por discriminar com veemência um certo grupo étnico e agir criminosamente com ataques a pessoas negras e execuções de muitas dessas pessoas. Nota-se que a imagem construída para o outro aparece no enunciado como um pressuposto, pois afirmar que os brancos agem pelo instinto com o intuito de se protegerem faz aparecer um outro que ameaça e destrói a harmonia entre a comunidade branca, e que portanto deve ser combatido. Enfatizar que se trata de um "mero instinto de auto-preservação" por parte dos brancos do "país sulista” (e aqui notamos que a nação americana é representada como dividida) anula qualquer possibilidade de atribuir as motivações do combate ao outro a questões políticas, por exemplo.

\footnotetext{
${ }^{13}$ Sociedade secreta norte-americana, fundada por veteranos sulistas após a Guerra de Secessão (1867). Seu objetivo inicial foi impedir que os negros se beneficiassem da abolição da escravatura. Proibida em 1877, em conseqüência de seus atentados racistas, foi reorganizada em Atlanta, em 1915 (Grande Enciclopédia Larousse Cultural. São Paulo: Nova Cultural, 1988).
} 


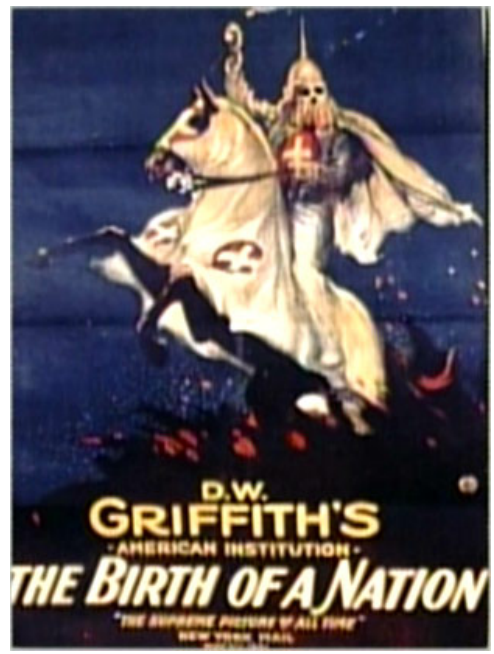

Figura 4: Cartaz do filme The birth of a nation (1915).

Cabe acrescentar que a trama foi baseada no livro The clansman, título que já faz alusão à organização, do escritor Thomas Dixon, e que o filme foi originalmente lançado com o mesmo nome do romance. Não antes de três meses é que o título foi mudado para The birth of a nation, na tentativa de fazer com que as palavras pudessem remeter mais diretamente ao propósito do filme, que, entre outros aspectos, é celebrar o fato de que não havia unidade em um país cujos estados não estavam em harmonia uns com os outros antes da Guerra Civil. Somente mais tarde, com a conquista do sul pelo norte, é que a nação teria efetivamente “nascido”. Segundo o argumento do filme, a presença da Ku Klux Klan se torna fundamental na resolução do conflito, pois tem a missão de restaurar a ordem no sul do país. Em filmes de épocas mais recentes, como se sabe, cabe a outras instituições (FBI e CIA, por exemplo) o mesmo papel celebratório e fundamental na história do país. Fica demonstrado que a cinematografia popular, já em seu momento fundador, reproduz, conforme afirma Kellner (2001), os discursos conservadores hegemônicos de determinado momento histórico. A administração do governo da época de produção do filme - Woodrow Wilson (1913 a 1921) teria sido marcada por políticas “antidemocráticas”, segundo Loewen (1995), como algumas medidas de segregação racial na distribuição de cargos durante seu governo, e esse aspecto interessa ao trabalho não pelo viés biográfico do presidente em questão, mas por aquilo que significa enquanto elemento das condições de produção das representações do filme.

Como a leitura do filme "O nascimento de uma nação" neste capítulo tem como objetivo apenas demonstrar como o discurso americano sobre o outro (estrangeiro, no caso) se reflete no cinema hollywoodiano já desde o surgimento desse tipo de representação, limitamonos a comentar alguns aspectos desse discurso observados na materialidade lingüística de alguns letreiros (como foi dito, trata-se um filme mudo) e em algumas imagens, sem o compromisso de análises mais minuciosas, as quais serão feitas no capítulo em que nos 
ocupamos especificamente do corpus principal composto de seqüências discursivas do filme “Nova York Sitiada”.

Vimos na parte do Capítulo I que trata sobre a construção de identidade que esta não é aqui tomada como fixa, estável ou, agora nas palavras de Coracini (2003), “como essência, lista de características mais ou menos fixas que [...] definem, ainda que por um tempo determinado, um indivíduo participante de um dado grupo” (p. 198). A autora esclarece que identidade passa a ser pensada, portanto, no sentido de "processo identitário" que, por sua complexidade, permite apenas que capturemos "momentos de identificação" (ibidem) do sujeito. Adotando o ponto de vista psicanalítico, a autora esclarece que a identificação com alguém ou algo pressupõe "um movimento que parte do exterior em direção ao interior, isto é, parte do outro em direção ao um, deixando no inconsciente recalques ${ }^{14}$,, os quais não se apagam e sempre irrompem em momentos futuros acionados por determinadas circunstâncias. No discurso analisado é possível argumentar que o sentimento de união é constitutivo do inconsciente norte-americano, o que equivale a afirmar que tudo que possa comprometer essa união é inevitavelmente percebido como estranho, em desarmonia com o ideal de nação estável. Nessa identificação do sujeito com tal sentimento ideal, essa alteridade não é descartada portanto, e existe como algo indesejável que persiste e aparece em momento oportuno, muitas vezes justificando certas declarações e atitudes. O que interessa observar é que a maneira como esse sujeito se relaciona com essa alteridade também revela o aspecto não fixo da identidade construída para a mesma. Assim, no discurso em questão, o outro que pode comprometer a união pode receber diversas configurações, como o nativo das terras do Novo Mundo, o escravo vindo da África, entre outras.

Essa característica de a construção de identidade estar sempre articulada em relação a uma alteridade pode ser observada no texto de um dos letreiros exibidos nos momentos iniciais do filme The birth of a nation: "The bringing of the African to America planted the first seed of disunion”. De saída, fica atestado que antes da chegada dos escravos africanos havia união no país, elevando o outro à condição de indesejável, com o qual o sujeito do enunciado não se identifica. A desunião da América é atribuída a um fator considerado externo, no sentido de não estar vinculado, por exemplo, a causas políticas internas. A propósito desse modo de lidar com a diferença que parece ser próprio do discurso norteamericano em vários campos, Bender (1993) observa que esse fenômeno está presente tanto

${ }^{14}$ NASIO, J. D. Lições sobre os 7 conceitos cruciais da psicanálise. Rio de Janeiro: Zahar, 1995, apud CORACINI (op. cit, p. 198). 
no lado religioso (puritanismo) quanto no secular, este fortemente influenciado por pensadores iluministas - ou seja, tal fenômeno estaria presente tanto no hierárquico quanto no igualitário. O autor observa que, a despeito das características contrastantes entre esses lados, “ambos rejeitam a diferença” (p. 51) a seu modo. Do lado religioso, essa rejeição não deveria causar estranheza, visto que aquele que não segue os preceitos de uma crença será inevitavelmente excluído em algum momento, mas essa rejeição por parte do pensamento secular também existe, segundo o autor, no ponto em que se considera o ideal comunitário, o qual pode revelar o funcionamento de um tipo de xenofobia. Bender observa isso no lado secular a partir de atitudes de intolerância, como no episódio das acusações sofridas pelos quacres na Nova Inglaterra no século XVII (p. 53). A noção de democracia privilegiada por Thomas Jefferson era também baseada em um conceito de valores, idealizando pequenas comunidades de agricultores e repudiando grandes centros. Concentrações humanas em lugares como Nova York, de acordo com a visão jeffersoniana, produziriam cidadãos com valores e interesses “marcados pela diferença ou até mesmo por sérios conflitos” (p. 53). Para Jefferson, o ser humano era destinado à sociedade porque era dotado naturalmente de um “senso de certo e errado” (op. cit.) e o político teria então escrito nas Notas sobre o Estado da Virgínia que "os negros são inferiores aos brancos tanto pelos traços do corpo quanto do espírito” (apud MESSADIE, 1989:29), atribuindo-lhes um senso moral e sustentando que havia neles a disposição ao furto.

Pêcheux (1988) nos fala do esquecimento $n^{o} 2$ como pertencendo ao domínio da enunciação, “pelo qual todo sujeito-falante ‘seleciona’ no interior da formação discursiva que o domina [...] um enunciado, forma ou seqüência, e não um outro” (p. 173) (grifos do autor), dando, assim, a impressão de que aquilo que dizemos só poderia ser dito daquela maneira (ORLANDI, 2002:65). Isso significa que o sujeito escolherá uma palavra e não outra (sem necessariamente se dar conta dessa seleção), como é possível constatar na materialidade lingüística de um outro letreiro do filme The birth of a nation, o qual parece mascarar o trabalho de manipulação ideológica: "This is an historical presentation of the Civil War and Reconstruction Period, and is not meant to reflect on any race or people of today”. Analisado em sua superficialidade lingüística, o emprego do “não” nesse enunciado funciona como uma maneira de asseverar que o objetivo do filme não é refletir sobre uma raça ou povo qualquer, porém, quando consideramos o efeito da denegação, pelo viés da psicanálise, podemos afirmar que o sentido pode sempre ser outro. A definição de denegação encontrada na Grande Enciclopédia Larousse é: “fato de enunciar um pensamento, um desejo, negando seu conteúdo ou não o reconhecendo como seu” - ou seja, o sujeito toma consciência, 
intelectualmente, de uma parte recalcada (a representação), porém mantém no inconsciente o afeto a ela associado.

A maneira como o discurso sobre o outro adquire visibilidade no cinema já em sua fase inicial mostra também que esse tipo de expressão cultural pode levar a cabo algum tipo de propaganda ideológica com grande eficácia, pois uma produção cultural que reivindica para si o objetivo único de apresentar um acontecimento histórico poderia ter sua veiculação até mesmo celebrada em virtude da qualidade a si atribuída de informativa. $\mathrm{O}$ aviltamento do outro nesse filme ocorre, sob vários pontos de vista, explicitamente e, apesar de o enunciado acima asseverar o contrário, o filme acaba apontando um inimigo contra o qual todos devem lutar.

A construção da figura do inimigo, como a história tem mostrado, pode ter como objetivo, em alguns casos, promover algum tipo de unificação em um determinado momento histórico. No filme que estamos analisando na tentativa de atribuir-lhe a condição de emblemático do discurso sobre o outro, essa idéia da existência de um inimigo que ameaça a ordem pode ser observada nos dizeres deste outro letreiro que é exibido também nos momentos iniciais acerca dos motivos que movem os idealizadores a produzirem The birth of a nation:

A plea for the art of the motion picture: We do not fear censorship, for
we have no wish to offend with improprieties or obscenities, but we
do demand, as a right, the liberty to show the dark side of wrong, that
we may illuminate the bright side of virtue - the same liberty that is
conceded to the art of the written word - that art to which we owe the
Bible.

Dizer que se exige, como um direito, a liberdade de mostrar "the dark side of wrong" coloca em cena a figura daquele que se opõe aos valores mais caros a uma sociedade. Aqui também é possível pensar sobre o efeito de denegação quando se afirma que "não" se tem o desejo de ofender quem quer que seja com impropriedades e obscenidades. Um dos efeitos de sentido produzidos por esse enunciado é de que as representações sobre o outro são pensadas como retrato da realidade. Talvez essa idéia em relação ao cinema também tivesse incentivado, com o crescente progresso das produções, a criação de teorias que iriam questionar essa suposta característica de um filme de representar a realidade. A recepção do filme por Woodrow Wilson teria sido calorosa, pois segundo várias fontes, o então presidente 
reagiu dizendo "It is like writing history with lightining, and my only regret is that it is all so true” (LOEWEN, 1995:18). A relação desse filme (e do livro) com Woodrow Wilson é bastante estreita, uma vez que a história é baseada no conteúdo do livro The history of the American people, escrito pelo próprio Wilson. Seu nome é também mencionado em um dos letreiros do filme.

A identidade que as representações sobre o negro em The birth of a nation acabam construindo é a de um indivíduo cujo caráter reflete as doutrinas imorais espalhadas pelos republicanos, incapazes de lidar politicamente com a autoridade que tinham conquistado, conforme sugere outro letreiro do filme: "In the villages the negroes were the office holders, men who knew none of the uses of authority except its insolences”. Afirmar que os negros só eram capazes de lidar com as insolências da autoridade implica considerá-los inferiores intelectualmente, incapazes de atingir o mesmo grau de democracia que caracteriza os brancos. A propósito, gostaríamos também de demonstrar como, na materialidade imagética do filme, os efeitos de sentido produzidos por meio da representação do outro nos revelam freqüentemente sua inferioridade em relação aos personagens principais. Em seu trabalho sobre a leitura das imagens, Kress e van Leeuwen (2001) lembram que, ao retratar figuras humanas, os produtores de imagem "must choose to make them look at the viewer or not, so they must also, and at the same time, choose to depict them as close to or far away from the viewer” (p. 130), observação que, no campo da AD, nos remete à interpelação do indivíduo em sujeito. Em todas as cenas de The birth of a nation (FIGURA 5) das quais o "personagem negro ${ }^{15}$ ” participa, a posição espacial deste no enquadramento é invariavelmente inferior à do branco, entendendo que nossa experiência com os mais variados tipos de expressão nãoverbal (gestos, posições, vestes, entre outros) construiu um campo de conotações do tipo “estar em pé e à frente” = estar em posição de superioridade. Exemplos incluiriam a imagem do professor, do palestrante; assim, nessa mesma relação, abaixar-se e curvar-se passam a ter a conotação de subserviência, inferioridade - ou seja, uma posição na qual o sujeito não tem direito à palavra a não ser que lhe seja concedido. A leitura dessas imagens sob tal perspectiva se torna pertinente ao trabalho pois mostra a emergência de um sujeito ideológico exatamente no ponto em que tem de lidar com uma alteridade, representando-a de uma maneira e não de outra, e que é própria desse sujeito enquanto constituído socialmente. Nesse filme é possível, portanto, constatar a presença do funcionamento de um discurso sobre o outro através do qual

\footnotetext{
${ }^{15}$ No elenco de “O nascimento de uma nação” há atores negros que atuam, porém também há casos em que atores brancos se maquiam com tinta escura para interpretar os papéis dos negros do sul. Essas caracterizações se mostram na maioria das vezes artificiais e rudimentares, tomando por referência a experiência do espectador atual, habituado com avançados métodos de “transformação” dos maquiadores de Hollywood.
} 
é colocado em operação o silenciamento de um dizer - ou seja, o outro aparece de algum modo, todavia é mostrado em uma posição de onde não consegue se expressar conforme os padrões de entendimento estabelecidos pelo filme e que se materializam em diálogos, argumentos, close dos rostos dos falantes. A inclusão do outro na história do filme significa também a sua exclusão.
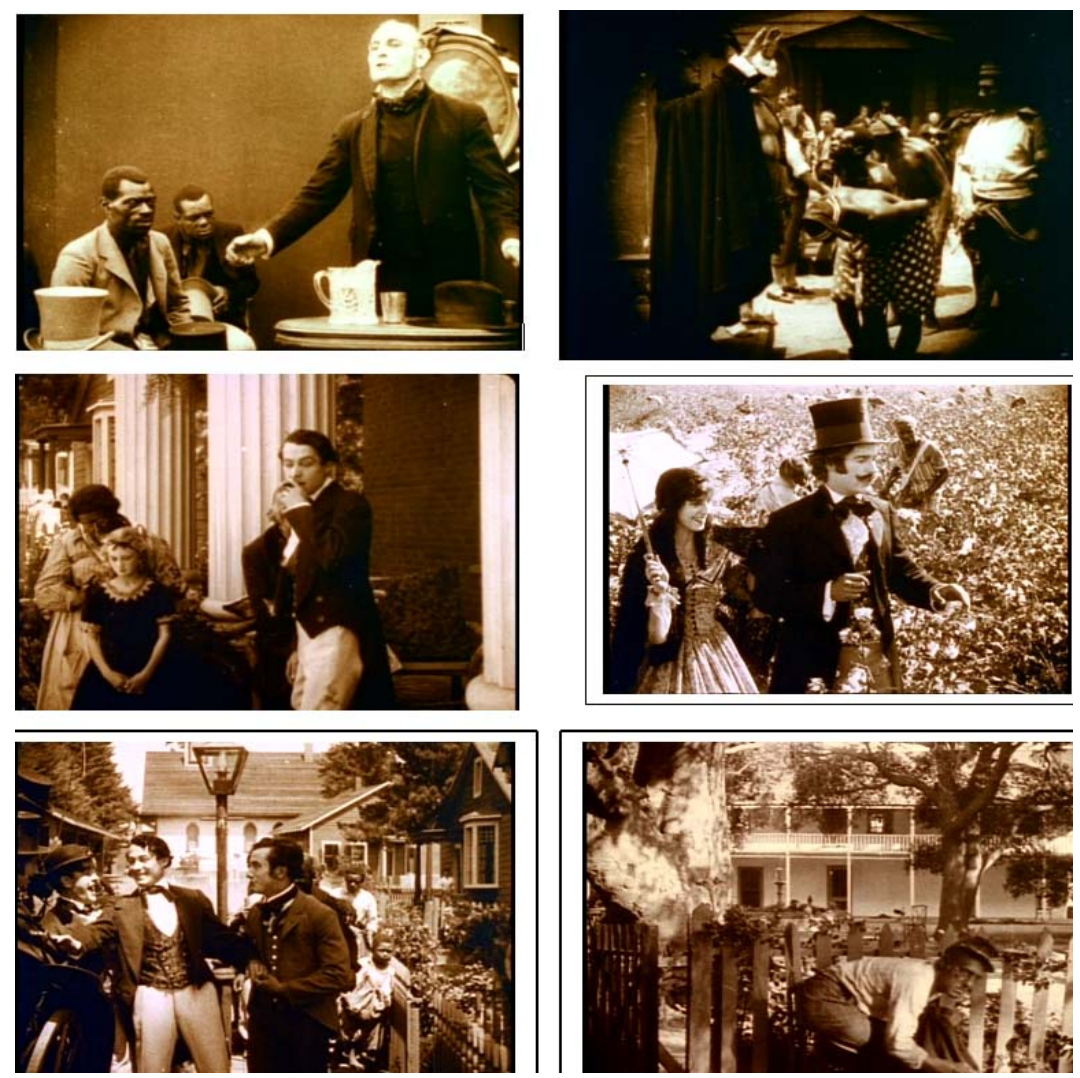

Figura 5: Cenas do filme The birth of a nation em que personagens negros interagem com personagens brancos.

\section{4 - A obsessão pela catástrofe no gênero “terrorismo”}

A lista de filmes hollywoodianos que exibem destruição em massa bem como a própria aniquilação dos Estados Unidos é extensa, portanto torna-se relevante compreender como essa obsessão pela tragédia se estrutura. Espectadores nas mais diferentes regiões do planeta já puderam assistir à destruição do edifício da Casa Branca por discos voadores de proporções gigantescas em Independence Day (1996), ao choque de um meteorito contra o edifício nova-iorquino Chrysler em Armageddon (1998), à invasão dos Estados Unidos por 
um exército de seres extra-terrestres em War of the worlds (2005) e, em tempos mais recentes, com a crescente preocupação em relação ao aquecimento global, ao cataclismo resultante da chegada de uma nova Era Glacial em The day after tomorrow (2004). É verdade que esses filmes inauguram um acontecimento que cria uma atualidade, porém sua estrutura se funda no dividido, o qual, inevitavelmente, nos transporta a um passado.

Bercovitch (1978), historiador da cultura norte-americana, sustenta que ecos de um determinado tipo de sermão criado pelos pregadores puritanos (a jeremíada ${ }^{16}$ ) podem ser ouvidos ao longo de toda a história dos Estados Unidos. Nesses sermões projetavam-se imagens apocalípticas com o objetivo de causar desconforto e amedrontar os norteamericanos, mas, ao mesmo tempo, de lhes mostrar que, na condição de povo escolhido para iluminar as trevas nas quais se encontravam os demais povos da terra, essas provações seriam necessárias para fortalecê-los espiritualmente. As imagens de final dos tempos projetadas nesses sermões típicos do período colonial da história dos Estados Unidos teriam se tornado fonte de inspiração também a autores que, em épocas históricas posteriores, já não apresentavam qualquer vínculo mais direto com a religiosidade. Mesmo antes do desembarque dos puritanos ingleses no Novo Mundo, sua história havia sido sempre marcada pela inquietação. Inquietos com relação à perseguição religiosa que sofriam na Europa, às condições da viagem que deveriam empreender até desembarcarem no Novo Mundo e também com relação à possibilidade que consideravam de algum tipo de violência por parte dos nativos quando já tivessem ali se instalado. Ao analisar historicamente esse fenômeno da apropriação de um tipo de adversidade para construir um determinado discurso de caráter disciplinar, Bercovitch (1978) nos mostra que:

From the start the Puritan Jeremiahs had drawn their inspiration from insecurity; by the 1670s, crisis had become their source of strength. They fastened upon it, gloried in it, even invented it if necessary. They took courage from backsliding, converted threat into vindication, made affliction their seal of progress. Crisis became both form and substance of their appeals (p. 62).

\footnotetext{
${ }^{16}$ Sermão caracterizado pela tentativa de convencer o ouvinte sobre os graves riscos que uma sociedade pode correr ao insistir em determinados comportamentos pecaminosos que desagradam a Deus. A palavra "jeremíada" deriva do nome do profeta Jeremias que, no Velho Testamento, acusa Israel de ter abandonado os preceitos de Jeová e optado por seguir os caminhos da idolatria dos pagãos, recebendo, por essa desobediência, o devido castigo.
} 
A certeza da condição de nação escolhida não excluía a possibilidade de esse povo se tornar alvo de ataques do inimigo; na verdade, acreditava-se que o fato mesmo de terem sido eleitos por Deus deveria justificar um maior número de chances de sofrerem ameaças por parte do outro que não conhecesse a luz divina, como ficou confirmado, do ponto de vista dos puritanos, já por ocasião das primeiras demonstrações de resistência dos nativos. Os sermões da época se beneficiavam dessas adversidades também para reafirmar a convicção dos ouvintes daquelas mensagens religiosas de serem diferentes dos demais povos da terra. Tais sermões cumpriam assim um papel que ia além da pregação do Evangelho, pois trabalhavam também no sentido de perpetuar a identidade do puritano como aquele que seria sempre provado por Deus para que pudesse realizar feitos cada vez maiores na Terra. Resumindo, para um puritano:

[E]verything happened for a reason. [...] If something good happened to the Saints, it was inevitably interpreted as a sign of divine sanction. But if something bad happened, it didn't necessarily mean that God disapproved; it might mean that he was testing them for a higher purpose. And as they all knew, the true test was yet to come (PHILBRICK, 2003:33).

Essa obsessão pela catástrofe, originalmente associada à questão da religiosidade dos puritanos, acabou se metamorfoseando em enredos de romances e, mais modernamente, em tramas de filmes. É verdade que a relação entre essas duas expressões culturais é bastante estreita, uma vez que muitos filmes são baseados em romances, como é o caso de War of the worlds, escrito por Herbert George Wells em 1898. Outra obra clássica norte-americana em que também se observa o fenômeno da obsessão pela catástrofe que se desenvolveu já na fundação do país é Moby Dick, de Herman Melville (1851). Nessa conhecida aventura, a caça à grande baleia branca funciona como uma alegoria da luta do homem contra as forças avassaladoras da natureza, e o fenômeno da obsessão pela catástrofe que temos exposto pode ser observado na destruição do obstinado capitão Ahab e da comunidade de seu navio Pequod, pois esse castigo funcionaria como plano de disciplina para um povo que precisa conhecer as conseqüências de certos atos insensatos. No romance “A cidade Quaker”, escrito por George Lippard em 1844, a cidade de Filadélfia também é destruída por uma revoada de figuras sombrias que descem do céu para castigar a corrupção do povo do lugar. Outro episódio também retratado em filme é o ataque da base aeronaval norte-americana de Pearl Harbor pela frota japonesa do almirante Yamamoto em 7 de dezembro de 1941, e o que 
interessa destacar a propósito desse evento que determinou a entrada dos Estados Unidos na II Guerra Mundial é que, seis décadas antes, Pierton Dooner havia escrito um romance no qual já tratava da “ameaça amarela”. Em “Os últimos dias da república”, Dooner apresenta uma grande massa de imigrantes chineses que, por se mostrarem dispostos a sacrificar a própria vida no trabalho árduo de construção das estradas de ferro norte-americanas, vencem todas as adversidades. Sobre as ruínas de Washington, descrita pelo autor do livro como o "Templo da Liberdade”, os chineses erguem sua bandeira, isto é, o pendão do “esplendor bárbaro”.

Sob a ótica da Análise do Discurso, poderíamos dizer que essa recorrência da exibição de imagens de catástrofes está ligada à noção de memória discursiva - ou seja, a toda formação discursiva, definida como o conjunto de enunciados marcados pelas mesmas regularidades e como aquilo que determina o que pode e deve ser dito, se vê associar uma memória discursiva que, por sua vez, é o que "torna possível a toda formação discursiva fazer circular formulações anteriores, já enunciadas” (BRANDÃO, 2004:95). É essa memória que possibilita que enunciados que pertencem a formações discursivas historicamente contíguas, apareçam, sejam rejeitados ou mesmo transformados. Se entendermos que esse tipo de obsessão é de certo modo constitutivo do discurso norte-americano sobre o outro (aquele que pode surgir a qualquer momento para causar certo dano), entendemos por que os efeitos de sentido produzidos pelos sermões do tipo jeremíada continuam ressoando mesmo em épocas de contextos diferentes, como mostram produtos culturais produzidos nos Estados Unidos enquanto duravam as tensões da Guerra Fria. É extensa a lista de filmes produzidos nos anos 50 que apresentam alienígenas invasores representando, metaforicamente, os comunistas.

Essa obsessão pela catástrofe que se mostra como uma característica significativa da cultura dos Estados Unidos não é, portanto, um fenômeno recente criado pelo cinema, porém este parece ter cooperado no sentido de torná-la mais visível. As representações feitas pelo cinema dentro de histórias nas quais essa obsessão se faz mostrar têm sempre variado conforme o momento histórico, logo, a identidade do outro ameaçador tem sido sempre reconstruída. Com o fim da Guerra Fria ${ }^{17}$, por exemplo, Hollywood elegeria como inimigo em muitas de suas produções a figura do terrorista bárbaro, e este apareceria com certa freqüência nos filmes catástrofes pelo menos até o ano de 2001. Estamos considerando esse ano como um possível momento de arrefecimento da tendência de explorar o tema terrorismo praticado por árabes por acreditarmos que os executivos de Hollywood teriam sido levados a

\footnotetext{
${ }^{17}$ Cabe dizer que não há consenso quanto ao momento exato em que a Guerra Fria teria terminado. Vale dizer que os ataques terroristas estão ligado à Guerra Fria também.
} 
reconsiderar tal temática em virtude do desconforto causado pelo episódio do 11 de setembro - ou seja, lidar com um tema como esse no campo da ficção envolveria mais reservas.

Entendendo o fenômeno dessa obsessão pela catástrofe como estrutural da cultura em questão, serão sempre questionáveis afirmações do senso comum como "a vida imita a arte”, pois o novo, o fora do comum de um filme não é produzido a partir do vazio, mas está diretamente vinculado às condições históricas do momento e se filia a uma determinada memória discursiva.

Não obstante o tipo de trama variar conforme o momento histórico, o que todas essas narrativas apresentam em comum, a exemplo dos sermões do tipo jeremíada, é o fato de que, após os danos causados pela catástrofe, emerge sempre uma mensagem que reforça a necessidade de recomeçar, reconstruir, reorganizar e reestruturar o que teria se fragmentado e afetado, portanto, o sentimento de união. A crise (real ou sua projeção) passa a ser de certo modo desejável, e enfatizá-la se torna mais urgente do que narrar, por exemplo, o bem-estar produzido por uma situação de paz. A título de ilustração e conclusão do capítulo, mesmo em um filme de animação como The incredibles (2001), o sentimento de regozijo após a derrota do inimigo é sucedido, momentos antes do the end, pelo desconforto causado pela mensagem de que um outro inimigo ressurgirá, sugerindo também ao espectador que o filme não termina ali. 


\section{CAPÍTULO III - O Oriente na visão ocidental}

\section{1 - Apresentação}

Muitas imagens e conceitos tomados como verdades universais do ponto de vista de detentores do saber como enciclopédias e livros didáticos ocultam, na maioria das vezes, seu caráter de construção, ou o fato de que esses saberes se instituem historicamente. A própria imagem do globo terrestre mais amplamente utilizada em publicações, aceita como representação legitimada e transparente do que foi produzido por geógrafos e como projeção de um objeto naturalizado, é passível de questionamentos. Ao optar por um determinado critério para a construção de uma imagem o indivíduo já está sendo interpelado em sujeito pela ideologia, como atestam as críticas existentes em relação a essa projeção mais conhecida do globo, a qual recebe o nome de "Projeção de Mercator ${ }^{18 " ~(F I G U R A ~ 6) . ~ S u s t e n t a-s e ~ q u e ~}$ essa imagem é de caráter eurocêntrico, uma vez que mostra o continente europeu em uma posição central da figura e distorce os dois extremos, produzindo assim a visão de uma América do Sul muito menor do que a Groenlândia, por exemplo. A nosso ver, os conceitos de Hemisférios Norte e Sul também revelam a presença do sujeito, visto que, para este, a idéia de "norte" estaria historicamente associada a sentidos de superioridade e maior visibilidade. Essas condições também estariam, dentro de outras redes de sentidos, associadas a poder e dominação. Desse modo, uma idéia que se naturaliza com o decorrer do tempo, já que esses motivos acabam sendo ignorados ou silenciados, poderá dar ocasião à construção de outras, como é possível notar, em caráter ilustrativo, em enciclopédias e dicionários que definem o Ocidente como:

Hemisfério Oeste da Terra, em relação ao meridiano de Greenwich ${ }^{19}$. - Conjunto dos povos e civilizações originários do oeste da Europa e da Europa mediterrânea. - Termo em uso a partir da década de 1950 para designar o conjunto de Estados do Pacto do Atlântico Norte, sob a liderança dos EUA. - Conjunto dos países capitalistas, por

\footnotetext{
18 Matemático e geógrafo flamengo (Rupelmonde 1512 - Duisburg 1594), foi o criador do método de representação cilíndrica direta conforme de uma esfera. Em cartografia, representa a superfície da Terra em um plano (planisfério), através de sua projeção sobre um cilindro tangente ao equador (Grande Enciclopédia Larousse Cultural, 1988).

${ }^{19}$ Linha imaginária que passa pelo subúrbio londrino de Greenwich, ligando os pólos Norte e Sul. Foi escolhido em 1884 como o meridiano inicial ou de origem ( $0^{\circ}$ de long.), a partir do qual se medem as longitudes e se contam os fusos horários, para leste ou para oeste (Grande Enciclopédia Larousse Cultural).
} 
oposição aos países socialistas ${ }^{20}$. The part of the world that includes Europe and North America $^{21}$.

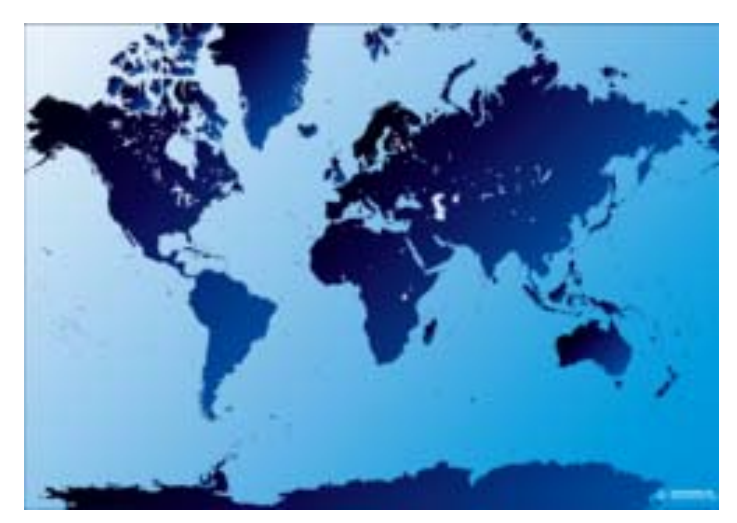

Figura 6: Projeção de Mercator

Na primeira definição, já a menção do meridiano de Greenwich deixa à mostra a historicidade do sentido e, portanto, uma opacidade, como o fato de que esses saberes estão associados a uma localização geográfica que nos remete a uma determinada identidade: a da credibilidade e legitimidade do pensamento europeu. A idéia de que um bairro londrino esteja vinculado à nomeação dessa linha imaginária pode parecer dissolvida ao longo da história, como se a palavra começasse a ser pensada a partir dela mesma; todavia, tais efeitos de sentido continuam se reproduzindo, visto que esses vínculos históricos são às vezes resgatados em situações nas quais a afirmação do sujeito se faz necessária. Tornam-se oportunos, por exemplo, na delimitação de espaço e determinação dos tipos de povos que devem ocupar determinados lugares em algum contexto sócio-cultural. Nos pólos normalmente idealizados para distinguir o avanço do atraso, o topo é ocupado por aquele que exerce influência com seu conhecimento e que, tomando as palavras de Silva (2002), "tem o poder de definir e determinar a identidade” (p. 91); no outro extremo, permanece aquele povo que deve se submeter a esses saberes, ou que não se enquadra no primeiro grupo. Alguns textos ilustram bem o que estamos expondo, como o ensaio de Henry Kissinger ${ }^{22}$ intitulado “A estrutura doméstica e a política externa”. Nele, a propósito da divisão que faz do mundo

\footnotetext{
${ }^{20}$ Grande Enciclopédia Larousse Cultural. São Paulo: Círculo do Livro, 1988.

${ }^{21}$ Macmillan English Dictionary. Oxford: Macmillan, 2002.

${ }^{22}$ Político norte-americano que atuou como conselheiro pessoal do então presidente Richard Nixon para política exterior entre 1968 e 1973. Foi o principal negociador para o fim da Guerra do Vietnã em 1973. Secretário de Estado sob o governo de Nixon em 1973 e de Gerald Ford entre 1974 e 1976, sua ação diplomática orientou-se depois para as conversações sobre sobre o conflito árabe-israelense (Grande Enciclopédia Larousse Cultural).
} 
em países desenvolvidos e países em desenvolvimento, o autor registra que "as culturas que escaparam do primeiro impacto do pensamento newtoniano retiveram a visão essencialmente pré-newtoniana de que o mundo real é quase completamente interno ao observador” (apud SAID, 2007:82) - ou seja, nessas subculturas não se entende que o conhecimento "consiste em registrar e classificar dados - quanto mais precisamente, melhor” (ibidem). Esse é um tipo de discurso político que promove a perpetuação da idéia de contraste entre Ocidente e Oriente, obedecendo sempre ao método de oposição binária, por meio do qual as características de dois aspectos são sempre mostradas a partir daquilo que têm de “diferente”.

Este capítulo pretende, primeiramente, expor alguns pontos acerca da historicidade dos conceitos Ocidente e Oriente e, como se pode depreender a partir do título, explorar imagens que são construídas sobre um dos pólos dessa divisão. É verdade que o estudo também é feito a partir de uma escolha, cuja justificativa é a disponibilidade de um volume maior desse tipo de material para ser analisado; todavia, não se pretende privilegiar tal lado da relação, até porque o olhar sobre essas imagens rebaixadas da alteridade pode contribuir, antes, para o entendimento da própria inquietação do sujeito que comanda essas representações diante da sensação de instabilidade da identidade que ele constrói e julga fixa até se deparar com crises que deixam à mostra sua movência.

Começamos traçando um breve panorama sobre como esses conceitos foram se instituindo até adquirirem um estatuto de verdade, evidentemente sem o compromisso de abarcar os inúmeros aspectos também envolvidos nesse percurso histórico, uma vez que, além de demandar uma exposição extremamente longa, tal investimento se distanciaria dos propósitos imediatos do trabalho. $\mathrm{O}$ “orientalismo ${ }^{23}$ ” que mais de perto nos interessa é aquele que, conquanto dialogue inevitavelmente com todo um arquivo de dizeres que está em constante processo de organização, começa a ser produzido mais recentemente na história, a partir do início do século XX, com a emergência dos Estados Unidos já como foco da ocidentalização. Em seguida, na tentativa de nos aproximar do objeto de estudo do trabalho, abordamos a construção da figura do oriental (sobretudo o árabe) na cultura popular do Ocidente, especificamente em algumas produções cinematográficas hollywoodianas. É a partir desse olhar que é possível apresentar alguns aspectos políticos relacionados à relação dos Estados Unidos com o Oriente Médio e a ligação dessa relação com a produção de determinado tipo de filme a partir dos anos 1970, o qual inscreveria o oriental árabe na

\footnotetext{
${ }^{23}$ Said descreve a abordagem ocidental do Oriente de maneira sistemática - ou seja, como tema de erudição, descobertas e práticas. Os aspectos da obra clássica desse autor, a despeito das críticas de outros orientalistas que apontam lacunas no trabalho, se tornam fundamentais para o desenvolvimento do presente trabalho por problematizarem a ideologia do orientalismo europeu e seus reflexos até a atualidade.
} 
cinematografia hollywoodiana já na condição de terrorista. Por fim, apresentamos alguns dos aspectos que costumam compor o perfil dessa alteridade construído pelo Ocidente justamente como o contraponto de valores defendidos discursivamente nas mais diversas manifestações pelo Ocidente, aqui já nos acercando ainda mais dos pontos para os quais chamamos a atenção ao longo da análise dos trechos do filme "Nova York Sitiada” que compõem o corpus.

\section{2 - Oriente: do florescimento à sua tradição}

Não há precisão quanto à origem (ou surgimento) do conceito de Oriente, pois essas idéias se desenvolvem e adquirem materialidade sob a ação de inúmeros fatores que contribuem para sua legitimação. É impossível negar o alcance desse conceito até os tempos atuais, pois se manifesta das mais diversas maneiras. Imageticamente, basta que nos lembremos, por exemplo, de figuras populares e recorrentes como a do beduíno sobre o camelo, do tapete mágico voador, da dança do ventre e da odalisca, entre outras até mesmo incorporadas à cultura brasileira, como a do xeique nas festas carnavalescas. Direta ou indiretamente, em tempos atuais, o Oriente é mencionado, discutido e mostrado com muita freqüência nos mais diversos domínios, através da literatura, imprensa, cinema e televisão. Porém, em tempos em que alguns desses dispositivos ainda não se faziam presentes, o Oriente não era abordado com menos vigor. Como entender isso dependeria, em um primeiro momento, da compreensão de que a idéia de um “oposto” dos valores privilegiados por uma determinada sociedade (invariavelmente dominante) sempre permeou a história. Comecemos por considerar um trecho da obra de Said (2007) em que, a nosso ver, o autor resume a idéia de existência do conceito de Oriente de maneira, poder-se-ia dizer, didática. O conhecido crítico literário e cultural nos convida a considerar como o Oriente, e em particular o Oriente Próximo, passou a ser conhecido no Ocidente como o seu grande oposto já desde a Antigüidade, de onde já podemos ter uma noção da extensão dessa tradição que ainda resiste no século XXI. Said segue então esclarecendo:

Houve a Bíblia e o surgimento do cristianismo; houve viajantes como Marco Polo que traçaram as rotas comerciais e padronizaram um sistema regulado de intercâmbio comercial, e depois dele Lodovico di Varthema e Pietro della Valle; houve fabulistas como Mandeville; houve os temíveis movimentos orientais de conquista, 
principalmente do islã, é claro; houve os peregrinos militantes, sobretudo os cruzados. Todo um arquivo internamente estruturado é construído a partir da literatura que pertence a essas experiências. Disso surge um número restrito de condensações típicas: a viagem, a história, a fábula, o estereótipo, o confronto polêmico. Essas são as lentes pelas quais o Oriente é vivenciado, e elas moldam a linguagem, a percepção e a forma do encontro entre o Leste e o Oeste (p. 96).

Rodinson (1989) aponta como uns dos fatores para o florescimento do orientalismo o estudo das línguas orientais que visava ao projeto missionário, como ocorreu na Espanha, durante a Idade Média (p. 65). O autor refere-se também aos estudos semíticos desenvolvidos em Roma na mesma época com o objetivo de promover a união das igrejas orientais (ibidem). O humanismo, buscando uma cultura universal e os interesses comerciais e políticos, iria depois ampliar esses estudos englobando-os, como prossegue Rodinson, “en un conjunto de estudios musulmanes” (ibidem). Esses estudos que cultivavam o orientalismo seriam mais tarde desvinculados das preocupações missionárias e, já na fase da imprensa, vários manuscritos seriam impressos, não apenas os de conteúdo religioso, mas os de conteúdos geográfico, gramatical e matemático, sem contar a impressão da obra médica e filosófica de Avicena $^{24}$ (ibidem, p. 66). Referindo-se mais diretamente a um dos aspectos apontados por Said mais acima (o literário), Eisele ${ }^{25}$ (2002), afirmando que essa tradição está presente já nas histórias e cantigas criadas a propósito das batalhas cristãs medievais contra os infiéis muçulmanos (as Cruzadas), esclarece que a mesma é representada em sua forma mais desenvolvida na obra “Jerusalém Libertada”, do poeta italiano do século XVI Torquato Tasso. Nos vinte cantos do poema épico, narra-se a tomada de Jerusalém pelos cavaleiros cristãos da primeira Cruzada em 1099 e, embora claramente do lado dos cruzados, o poeta retrata tanto os cristãos como os cavaleiros muçulmanos como símbolos do melhor e do pior das tradições feudais da cavalaria (p. 69).

Nesse percurso de florescimento de uma tradição orientalista, temos os artistas e pensadores do Iluminismo, que também contribuíram, com seus trabalhos, para o êxito do processo de construção da noção de Oriente com as características que têm sido sempre difundidas. Se, por um lado, esses artistas também procuravam criticar, como observa Eisele (2002), “the faults of European culture”, por outro, seus trabalhos contribuiriam para

\footnotetext{
${ }^{24}$ Referência ao nome em árabe Abu 'Alli al-Husayn ibn Sina, filósofo e médico iraniano (980-1037). Seu "Cânon da Medicina" foi traduzido para o latim e teve grande influência na Europa até meados do século XVII (Grande Enciclopédia Larousse Cultural).

${ }^{25}$ John C. Eisele, professor de árabe no Departamento de Letras Modernas e Literaturas da faculdade norteamericana College of William and Mary, em Williamsburg (Virginia).
} 
expressar o lado “negativo” atribuído ao Oriente, especificamente em relação à ameaça real ou potencial militar das campanhas otomanas na Europa Central. No campo das belas artes, artistas da corrente orientalista como Delacroix, Ingres, Decamps e Fromentin legaram um arquivo imagético sobre o Oriente com suas pinturas inspiradas em um lugar exótico e, na maioria das vezes, fictício, porque se baseavam sobretudo em relatos e testemunhos de viajantes.

Quanto aos conceitos em si, como Said (2007) vai reafirmar no prefácio ${ }^{26}$ da reedição de seu Orientalismo, “nem o termo ‘Oriente’ nem o conceito de 'Ocidente’ têm estabilidade ontológica; ambos são constituídos de esforço humano - parte afirmação, parte identificação do Outro” (p. 13). Essa (re)afirmação evidentemente traz pressuposta a idéia central da obra do autor, para quem o Oriente é uma invenção do Ocidente, uma idéia que não apenas nos remete a um lugar misterioso e exótico além daqui, em termos geográficos, mas também à idéia de que há estilos de vida, comportamentos, crenças e modos de pensar inferiores àqueles que a sociedade dominante conhece. Para que algo não natural se naturalize, é necessário o esforço, em todas as épocas, de constantes mobilizações e articulações no sentido de fazer prevalecer a noção de superioridade das instituições de quaisquer povos que investem em perpetuar alguma posição de vantagem.

De modo geral, pode-se dizer que, a despeito de representações celebratórias do Oriente produzidas por artistas da época das luzes interessados em seus temas, a maneira de pensar esse lugar outro desde muito tempo (antes mesmo do Islã) remeteu a uma certa negatividade que a obscuridade a ele atribuída carregava, pois foi com a idéia de perigo que os árabes, conhecidos como sarracenos pelos europeus na Idade Média, foram primeiramente identificados. É o que Rodinson (1989) nos mostra quando, referindo-se a trechos do diário de viagem de um autor desconhecido do século IV na obra "Expositio totius mundi et genium”, cita a parte dessa obra que reduz a descrição dos árabes ao aspecto nômade de seu estilo de vida: um povo que buscava, “mediante el arco e la rapiña”, tudo que era necessário para viver (p. 25). Nada além dessa característica predadora importava saber em relação aos árabes.

Sua existência para o povo europeu só se tornaria mais concreta cerca de um século após a morte do profeta Maomé, por ocasião da chegada dos muçulmanos ao continente, justamente quando a Península Ibérica foi invadida. A hegemonia do islã, tanto militar quanto cultural e religiosa, cresceu enormemente após a morte do profeta, como afirma Said (2007:97). Não apenas a Espanha, mas a Sicília e partes da França, foram conquistadas, fatos

\footnotetext{
${ }^{26}$ Esse foi o último adendo do autor à sua clássica obra, no ano de 2003. Orientalism foi lançado em 1978.
} 
que fizeram com que a imagem dos exércitos muçulmanos associada à ameaça e ao terror adquirisse contornos cada vez mais definidos. Subjugados, os cristãos da Espanha muçulmana, conhecidos como moçárabes, tiveram que construir então, segundo Rodinson, uma imagem mais “exata” (p. 25) daqueles que os dominavam, visto que a ameaça árabe se fazia agora presente. Essa alteração no modo de perceber o outro por parte da população sofreria também a influência do trabalho de intelectuais, os quais estariam se articulando no sentido de preservar os valores locais, especialmente no campo da fé. Desse modo, o processo de construção de imagens injuriosas, especialmente quando estas são legitimadas pelas idéias de intelectuais, começa a inaugurar novas discursividades. Há uma ameaça física presente, todavia as idéias propagadas em relação a esse “impostor” adquirem novas abordagens à medida que o Ocidente vai se articulando para se defender, e é então que podemos observar com mais clareza o caráter de construção do Oriente por parte do Ocidente, à semelhança do que se observa em tempos atuais quando tomamos como referência a maneira como o oriental árabe, sobretudo quando pensado a partir da fé com que é identificado, continua sendo ainda associado à barbárie, à heresia e poligamia. Destacamos acima o termo “impostor”, visto que tal foi o epíteto que, segundo Said, a partir de sua leitura de Norman Daniel ${ }^{27}$, Maomé ficou conhecido no campo das idéias criadas pelos ocidentais. Supunha-se que o profeta fosse para o islã exatamente o que Cristo era para o cristianismo, e dessa analogia resultou também o termo “maometismo” dado ao islã (p. 99), ambas as idéias criticadas pelo primeiro autor, visto que nesse modo de entender a crença do outro está implícita a idéia de que o Oriente tenta imitar a matriz da verdade ocidental e, em fazendo-o, peca, porque tenta disseminar uma falsa Revelação que traz consigo, nos dizeres de Said, “toda uma bateria de diversas traições, todas derivadas 'logicamente' de suas imposturas doutrinárias” (p. 101). A idéia de origem e de legitimidade atribuída ao Ocidente se torna fundamental para assegurar o contraste, qualquer que seja domínio, entre esse dois pólos. O modelo a ser seguido tem sua matriz no Ocidente, legitimada por seus pensadores, artistas e líderes religiosos.

Concluindo essa primeira exposição, importa entender aquilo que Said chama de "geografia imaginativa” para também entendermos esta construção mais recente do Ocidente: o Oriente Médio. Esse tipo de prática de designar um espaço para o outro é sempre de caráter arbitrário, segundo o autor, visto que "não requer que os bárbaros reconheçam a distinção” (p. 91). O termo Oriente Médio foi uma criação “de cunho técnico e marcada por influência militar” (AKCELRUD, 1986:5) que teria ocorrido no início do século XX, mais precisamente

\footnotetext{
${ }^{27}$ DANIEL, N. Islam and the West: the making of an image. Edimburgh: Edimburgh University Press, 1960, p. 33, apud SAID (op. cit., p. 99).
} 
em 1902, para designar a área compreendida entre a Arábia e a Índia, tendo como centro o Golfo Pérsico, identificando, assim, o "momento preciso em que os interesses petrolíferos entraram definitivamente no planejamento estratégico das grandes potências” (ibidem). A esse respeito, Karnal (1994) dirá que, desde que o petróleo jorrou pela primeira vez no Irã espetacularmente, “empresas estrangeiras começaram a demonstrar um interesse imenso pelo Oriente Médio, acelerando a vontade de desmembrar o Império Otomano - que dominaria toda a região até 1918” (p. 12). Olic (1997) lembra também que a Grã-Bretanha tinha um interesse especial pelas regiões dominadas pelo já fragilizado domínio otomano, por ser o Oriente Médio “uma área de passagem para atingir sua principal colônia na Ásia: a Índia” (p. 17). Com os trabalhos de exploração de geólogos europeus no Iraque logo no início do século $\mathrm{XX}$, as regiões do antigo Império Otomano começavam a atrair cada vez mais a atenção das grandes potências de então, e o Oriente Médio emergiria como uma área de grande interesse internacional. É verdade, no entanto, que não há precisão em relação à conceituação geográfica do termo Oriente Médio, podendo variar segundo a fonte das definições, visto que, em uma acepção mais ampla, a área pode também abranger o conceito de Oriente Próximo (península da Anatólia, Síria). A rigor, os países que costumam ser incluídos no conceito de Oriente Médio incluem o Iraque, a Jordânia, o Irã, o Afeganistão, os países costeiros do Mediterrâneo oriental (da Turquia ao Egito) e a península arábica. O conceito pode se estender também à Líbia, ao Sudão e mesmo aos países do subcontinente indiano, sobretudo o Paquistão. Apesar dessa imprecisão geográfica, o que costuma caracterizar o Oriente Médio é a presença majoritária dos povos árabes e o domínio do islã. Este é o resultado, segundo Olic (ibidem), da influência do expansionismo árabe, que legou à região a língua e a religião (p. 17). O que interessa observar na exposição dessa denominação recente (e eurocêntrica, como nota Akcelrud), é a constatação do fato mesmo de que o Ocidente traçou e continua traçando novas fronteiras, dando ocasião à fabricação de outras imagens que possam sempre marcar a diferença entre dois pólos, sempre em conformidade com a emergência de novos enunciados e novos discursos produzidos na relação com outros. 


\section{3 - A inscrição do oriental árabe nos filmes de Hollywood}

As diversas identidades construídas para o oriental árabe no cinema, já desde o seu advento em manifestações embrionárias da fase do cinema mudo, variam de acordo com o contexto histórico em questão. Todavia, em seu artigo "The wild West: deconstructing the language of genre in the Hollywood eastern”, Eisele observa uma certa coerência na longa lista de filmes que lidam com o Oriente, independentemente do gênero, já que todos apresentam como aspecto comum a presença de determinados elementos narrativos. Ao traçar um panorama histórico da cronologia dos filmes que exploram essa temática desde a fase inicial do cinema, sobretudo no contexto norte-americano, como é o caso de The terrible Turkish executioner (1905), Eisele aponta alguns desses principais elementos: aprisionamento, mutilação ou ameaça de amputação com a cimitarra, resgate, rapto de mulheres seguido de sua escravização em haréns, rapto de homens seguido de sua escravização em celas, confusão de identidade e retratação do Oriente como um lugar de terror e redenção de pecados. A coerência também se observa na exibição de desertos, tempestades de areia, camelos e turbantes, entre os elementos mais freqüentes. Esse filme de 1905 pode ser considerado uma das mais antigas formas de representação do Oriente Médio no cinema. Nos poucos minutos de sua duração, mostra um algoz decapitando quatro prisioneiros com um único golpe de cimitarra, marcando o início de uma tradição que Eisele chamará de "gênero oriental”. Esse gênero incluiria, por exemplo, histórias como a das mil e uma noites, do ladrão de Bagdá, sem falar de um tipo de filme (sheik movies) que acabou se popularizando após o êxito de The sheik, protagonizado por Rodolfo Valentino tanto em 1921, na sua primeira versão, como na sua seqüência (The son of the sheik), em 1926. Produções mais recentes, como o desenho animado da Disney Aladdin (1992), também se encaixariam nesse eastern film genre. Segundo $\mathrm{Hajji}^{28}$, este era o tipo de filme mais popular nas duas primeiras décadas da história do cinema, e o autor lista outros títulos que surgiram no período, como A tale of a harem: the caliph and the pirate (1908), The captive (1910), Captured by the bedouin (1912), A prisoner in the harem (1913) e Saved from the harem (1915). É importante observar que a popularidade de The sheik também se deve a seu caráter de influência nas normas culturais e da provocação de discussões fora do cinema na ocasião de seu lançamento. Já em um estágio mais consolidado e sonoro do cinema, outras produções se tornaram

\footnotetext{
${ }^{28}$ Abdelmajid Hajji, "The Arab in the American silent cinema: a study of a film genre", dissertação de doutorado, University of Kansas, 1994 (apud EISELE, op. cit.)
} 
igualmente célebres, como Lawrence of Arabia (1962) e Cleopatra (1963). Trata-se portanto de uma tradição cinematográfica de filmes que exploram temas do Oriente, como procuramos mostrar cronologicamente na Figura 7, que acaba justificando muitos trabalhos investigativos sob perspectivas diversas. Mais recentemente, o tipo de filme dentro desse gênero que passou a atrair a atenção de pesquisadores é aquele que lida com terrorismo. São inúmeros os trabalhos que abordam a questão da demonização do árabe nesses roteiros, invariavelmente criticando o reforço dos estereótipos pelos quais o Oriente é visto no mundo eletrônico pósmoderno. Sobre esse recorrente tipo de representação sobre o Oriente, Said (2007) vai dizer que “a padronização e os estereótipos culturais intensificaram o domínio da demonologia imaginativa e acadêmica do 'misterioso Oriente’ do século XIX” (p. 58), mas a verdade é que esse formato de filme é uma criação mais recente da indústria cinematográfica, em comparação com os outros tipos já citados. Os elementos narrativos do gênero se repetem, de alguma maneira, com o personagem árabe no papel do antagonista, mas as condições de produção diferem, evidentemente, no caso do filme sobre terrorismo.
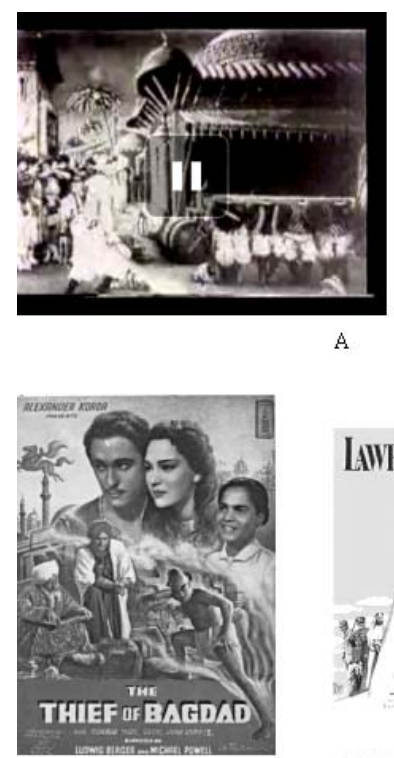

D

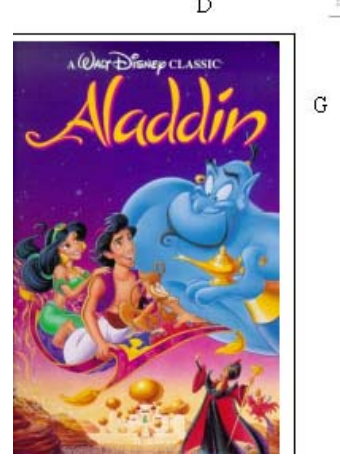

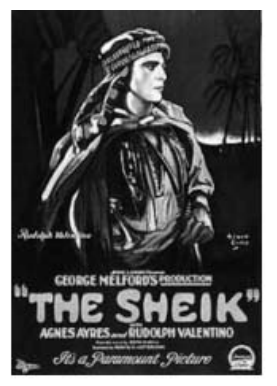

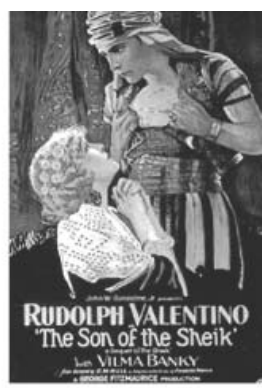

B

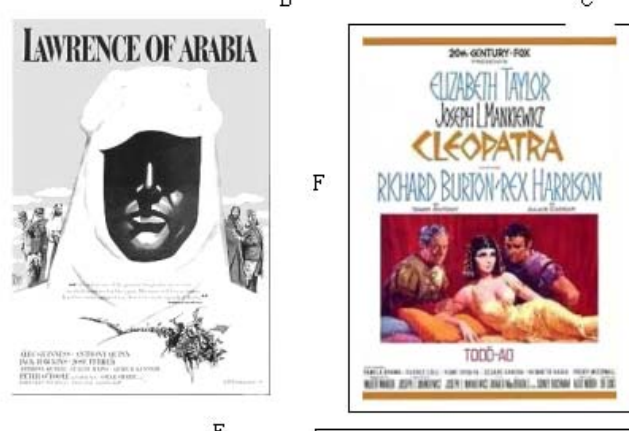

E

The terrible Turkish The sheik (1921).

B. The sheik (1921).
C. The son of the sheik (1926)]

D. The thief of Bagdad (1940)

Lawrence of Arabia

F. Cleopatra (1963)

G. Aladdin (1992)

Figura 7: Filmes que fazem referência ao Oriente. 
Dentre as razões apontadas para o surgimento desse tipo específico de filme em Hollywood nos anos 1970 sobressai a questão política. No início do século XX, os árabes não eram considerados uma ameaça aos interesses norte-americanos particularmente, e Eisele observa, em caráter de fundamentação, que eles até mesmo apoiaram a causa dos Aliados contra o Império Otomano durante a Primeira Guerra Mundial (p. 72). No entanto, as ocupações sionistas na Palestina provocariam grande resistência da população árabe diante da perda de suas terras e da soberania, e a fundação de Israel em 14 de maio de 1948, em conformidade com uma resolução da Assembléia Geral da ONU, deu início a várias guerras entre o jovem Estado e as nações árabes limítrofes como o Egito, Líbano, Síria, Iraque e Transjordânia. Essa região passou então a ser considerada uma área de constante tensão política, com o início de atividades terroristas se intensificando com a regularidade dos conflitos. Essa questão iria assim dominar a diplomacia do Oriente Médio desde então. Eisele sustenta, no entanto, que o povo árabe, à frente desses confrontos constantes, apenas assombrava a imaginação dos Estados Unidos “from the margins” (ibidem, p. 72); sua condição de real ameaçador aos interesses norte-americanos ocorreria mais concretamente somente durante o embargo de petróleo de 1973. Para o autor:

This event, together with the expansion after 1971 of the PLO's guerrilla/terrorist campaign against the Israelis, led to the Arab being represented as embodying the antithesis of Western values and rationality in the popular narratives of films and television (2002:71).

Em Olic (1997), encontramos outro aspecto que teria contribuído para transformar o Oriente Médio em uma das regiões de maior tensão para o mundo contemporâneo ocidental, sobretudo quando este é pensado a partir do papel hegemônico ocupado pelos Estados Unidos. O aspecto destacado por Olic é a revolução islâmica iraniana. A derrubada do então xá Mohamed Reza Pahlevi, em 1979, e a ascensão do aiatolá Khomeini também teriam sido fatores importantes no recrudescimento do conflito entre o Ocidente e o Oriente. Como se sabe, Reza Pahlevi contava com o apoio norte-americano para instituir o programa de reformas que chamou de Revolução Branca, e o aiatolá, seu inimigo declarado, sempre esteve no comando do movimento xiita de insurreição popular tanto antes de ter sido preso e exilado, em $1963^{29}$, quanto após ter retornado ao Irã exatamente por ocasião da revolução.

\footnotetext{
${ }^{29}$ Grande Enciclopédia Larousse Cultural.
} 
Entre os fatores que contribuíram para a inauguração de novas discursividades em relação ao Oriente Médio, pode-se também incluir o atentado sofrido por nove atletas israelenses durante os Jogos Olímpicos de Munique em 1972. Esse episódio atribuído a operações terroristas da Palestina seguramente contribuiu para o florescimento de filmes que passaram a incluir em suas tramas ações violentas de terrorismo praticadas por muçulmanos. Com isso, a imagem do oriental árabe como terrorista começa também a fazer parte do conjunto de elementos narrativos com que o Oriente já era abordado no cinema. As noções de mistério e exotismo são mantidas, porém a idéia de barbárie atribuída a esse outro adquire ainda mais força, tornando-se o elemento com que o oriental árabe passa a ser mais facilmente identificado no cinema.

Um dos aspectos que marcariam a diferença entre os filmes que já abordavam o Oriente antes do desenvolvimento do subgênero "terrorismo" está relacionado ao próprio lugar em que as tramas são ambientadas. Esse lugar invariavelmente era o Oriente Médio, normalmente um país árabe, mas ocasionalmente, como esclarece Eisele, a Turquia, o Irã ou Israel, com todos os elementos narrativos do gênero adquirindo maior expressão. Nos filmes sobre terrorismo, esse ambiente se desloca para o próprio solo norte-americano, como é o caso do primeiro filme sobre terrorismo de maior popularidade: Black Sunday (1977). Entre os principais filmes que iriam explorar esse tema a partir de então, destacam-se True Lies (1994), Executive Decision (Momento Crítico, 1996) e The Siege (Nova York Sitiada, 1998). O Oriente começaria a ser representado como um lugar ao mesmo tempo distante (uma outra língua, vestes e costumes diferentes) e próximo da realidade do Ocidente, porque seu povo estaria agindo no próprio espaço do agredido.

Essa fase mais recente do Orientalismo está muito associada com a própria sofisticação dos meios de comunicação, com o início das operações de canais exclusivos de notícia com transmissões em tempo real. Como se sabe, a Guerra do Golfo marcou o início de uma nova fase da imprensa, mais precisamente com as reportagens da CNN em 1991. Karnal (1994) lembra que "pela primeira vez na história o resto do globo podia acompanhar quase ao mesmo tempo o início de um conflito bélico” (p. 42). Do mesmo modo, Arbex Jr. (2005) afirma que uma nova fase do uso da mídia como "arma de guerra” teve início com a Guerra do Golfo, e o autor chama a atenção para o modo como a televisão costumava mostrar os soldados americanos em contraste com a exibição de cenas que remetiam ao lado árabe. Enquanto os primeiros eram mostrados beijando suas esposas e filhos antes de partir para a guerra, o outro era exibido "como um mundo exótico, quase irreal, em que as mulheres usam longos véus e camelos eram vendidos em praças públicas” (p. 144). O objetivo já era, 
conforme sustenta o autor, criar a percepção de que o misterioso Islã, representado por Saddam Hussein, era o novo inimigo do “mundo livre” (ibidem). Já empregando termos da análise do discurso, trata-se de um acontecimento que deve ser pensado como "a emergência de enunciados que se inter-relacionam e produzem efeitos de sentido” (GREGOLIN, 2006:27). Esses enunciados vão constituindo um novo arquivo ${ }^{30}$, e meios de comunicação como a televisão e o cinema, por exemplo, figuram como dispositivos fundamentais nesse processo. A emergência de um enunciado não ocorre em um vácuo histórico, mas pressupõe uma estrutura de outras enunciações com a qual o "novo" enunciado se articula. A presente exposição de aspectos ligados ao Oriente pretende mostrar justamente essa relação que os enunciados estabelecem dentro do “arquivo” de uma época (ibidem, p. 27).

Com base nessa noção de acontecimento e de arquivo, a Guerra do Golfo se insere, portanto, em um contexto de outros enunciados, e os produtos da cinematografia hollywoodiana, como mostra Kellner (2001), também revelam uma relação com esse acontecimento mesmo antes de sua instauração. Para o autor, que tenta mostrar com sua acurada análise de diversos filmes norte-americanos como o cinema pode funcionar a serviço das forças socioeconômicas dominantes, várias produções cinematográficas contribuíram para preparar os Estados Unidos para essa guerra “ao celebrarem as virtudes do armamento hightech e do heroísmo militar, criando um inimigo árabe para substituir o arquiinimigo soviético e fazendo propaganda da política externa de Reagan e Bush [pai]” (p. 115). Kellner defende que a própria hegemonia conservadora dos anos 1980 e início dos anos 1990 contou também com a participação do cinema no sentido de preparar o país para esses governos através de vários filmes de suspense político produzidos nos anos 1970. Na trama desses filmes, os árabes já eram representados como assassinos de vítimas inocentes, como em Black Sunday (1977), e Nighthawks (1981) ou como capitalistas gananciosos em filmes de intriga financeira como Network (Rede de intrigas, 1976) e The formula (1980). Já entre os filmes de que o autor se serve para justificar sua hipótese de que coube a Hollywood parte do papel de apontar o inimigo que substituiria o soviético, estão incluídos Iron Eagle I (1985) e Iron Eagle II (1988). As duas versões de Iron Eagle retratam já o começo de uma distensão nas relações com a União Soviética, e dão início à produção do "novo superinimigo” que, fora das telas, seria encarnado por Saddam Hussein (o personagem ditatorial do filme apresenta as

\footnotetext{
30 "Os enunciados que circulam em um certo momento histórico constituem um arquivo, isto é, o conjunto de todos os textos efetivamente produzidos. Como a produção e a circulação dos sentidos são reguladas por regras sócio-históricas, o arquivo expressa o que pode ser dito, o sistema que rege o aparecimento dos enunciados como acontecimentos singulares” (GREGOLIN, 2006:27).
} 
características físicas do então líder iraquiano). Justificando sua tese de que os propósitos do cinema vão além da finalidade de entretenimento, Kellner afirma que a primeira versão de Iron Eagle teria também recebido ajuda financeira do governo de Israel, o qual forneceu aviões F-16 e Phantoms, pilotos e consultores militares (p. 115). Na ficção do primeiro Iron Eagle, por exemplo, um país árabe não identificado informa que os aviões americanos violaram seu espaço aéreo, fato este que justifica a tortura imposta ao piloto, que é condenado à morte arbitrariamente. No segundo Iron Eagle, Hollywood já mostra mais claramente o afrouxamento da tensão entre Estados Unidos e a União Soviética ao apresentar um projeto conjunto entre as duas potências com o fim de destruir uma instalação secreta dos árabes, episódio que reproduz, segundo a análise de Kellner, o bombardeio de Israel na instalação nuclear do Iraque em 1981.

Por apresentarem imagens negativas dos regimes árabes e dos “terroristas”, esses filmes contribuíram, segundo o autor, para fomentar sentimentos antiarábicos, trazendo à tona, portanto, a emergência de novos enunciados que permeariam outras produções cinematográficas do gênero, como pode ser observado nas tramas de filmes da época Reagan/Bush como The Delta Force (Comando Delta, 1986), Death before Dishonor (Pelotão da Vingança, 1987) e Navy Seals (Comando Imbatível, 1990). Em todos esses filmes, atualiza-se um acontecimento (o fato de que há uma 'nova' ameaça aos interesses do Ocidente), no entanto, ao mesmo tempo, resgata-se toda uma memória discursiva já existente com a tradição de representações do Oriente no cinema.

\section{4 - A racionalidade como contraponto entre o Oriente e o Ocidente}

No contraste geralmente feito entre Ocidente e Oriente enfatiza-se, com certa freqüência, o aspecto da racionalidade como sendo uma característica própria do primeiro e ausente no segundo, ainda que a referência a essa ausência nem sempre seja declarada. A compreensão dessa percepção eurocêntrica do oriental começa a ocorrer já em textos como os de lorde Cromer, o qual, no capítulo 34 de sua obra sobre o Egito, estabelece, conforme considera Said (2007), “uma espécie de cânone pessoal da sabedoria orientalista” quando afirma, a propósito de uma declaração que teria ouvido de Sir Alfred Lyall, que:

A precisão é incompatível com a mente oriental. [...]. A falta de precisão, que facilmente degenera em insinceridade, é de fato a principal característica da mente 
oriental. O europeu é um bom raciocinador; suas afirmações factuais não possuem nenhuma ambigüidade; ele é um lógico natural, mesmo que não tenha estudado lógica; é por natureza cético e requer provas antes de aceitar a verdade de qualquer proposição; sua inteligência treinada funciona como um mecanismo. A mente do oriental, por outro lado, como as suas ruas pitorescas, é eminentemente carente de simetria. Seu raciocínio é dos mais descuidados. Embora os antigos árabes tivessem adquirido num grau bem mais elevado a ciência da dialética, seus descendentes são singularmente deficientes na faculdade lógica. São muitas vezes incapazes de tirar as conclusões mais óbvias de quaisquer premissas simples, das quais talvez admitam a verdade. Procurem extrair uma simples declaração de fatos de qualquer egípcio comum. Sua explicação será geralmente longa e carente de lucidez. (apud SAID, p. $71)$.

A barbárie, como a decisão de adotar a violência como solução de embates, seria uma das maneiras pelas quais essa ausência de racionalidade e carência de lucidez atribuídas ao oriental se tornam visíveis, na concepção ocidental, já que agressões violentas costumam caracterizar justamente os animais, que agem unicamente pelo instinto, excluindo qualquer possibilidade de argumentação. No trecho de um ensaio publicado no American Journal of Psychiatry de que Said (2007) se serve para criticar as afirmações de orientalistas quando estes discutem o aspecto da racionalidade, seu autor ${ }^{31}$, procurando revelar como funciona internamente o comportamento árabe, conclui que eles “só funcionam em situações de conflito [...] para os árabes, a situação não é regida por essa espécie de lógica [criação da paz], pois a objetividade não é um valor no sistema árabe” (p. 84). Esses textos científicos do Ocidente que se revestem de autoridade legitimam modos de pensar o outro como aquele para quem não importam os meios empregados para se atingir determinado objetivo, invariavelmente dentro de uma situação de vingança, uma vez que esses pensadores procuram fundamentar seu argumento de que vingar-se, para o árabe, é visto como um valor que tem como fim apagar a vergonha de alguma ofensa sofrida.

Por outro lado, o Ocidente procura dar visibilidade a seu investimento em empregar com propriedade a faculdade de raciocinar quando, por exemplo, enfatiza o ideal de democracia e a importância da diplomacia, contrapondo-se à posição que, segundo essa mesma retórica dominante, é assumida por seu antagonista. Tomando esse tipo de contraste, enquanto o Ocidente se mostra como defensor da liberdade de expressão, do direito de ir e vir

\footnotetext{
${ }^{31}$ Harold W. Glidden.
} 
e da aprendizagem, o seu oposto é mostrado como aquele que preza os sistemas autoritários que cerceiam a liberdade de seus próprios povos e punem arbitrariamente qualquer indivíduo que seja, pertencente a seu grupo ou não. É verdade que o modo como esse contraste é mostrado varia de acordo com o período histórico, as tensões do momento em questão e também com a natureza do dispositivo. O cinema, por exemplo, se beneficia do aspecto imagético para assinalar esse contraste nas cenas de violência atribuídas ao outro, como mostram alguns dos filmes citados acima; já na literatura do meio acadêmico, esse contraste recebe outro tipo de tratamento. O especialista em mundo árabe e islâmico Bernard Lewis, um dos principais conselheiros do Pentágono no governo de George W. Bush e autor de "O que deu errado no Oriente Médio?”, enumera diversas razões para o atraso do mundo oriental de hoje, como o fato de que, segundo sua visão, os povos do Oriente Médio, no passado, não se preocupavam em observar o Ocidente da maneira como o Ocidente já observava o seu outro, deixando revelar também aqui um discurso sobre a valorização da habilidade ocidental em antecipar-se, justamente porque faz uso da inteligência e da racionalidade. Lewis contrasta o interesse ocidental e o desinteresse oriental sobre o que ocorria em outras partes do mundo sustentando que, enquanto as potências européias mantiveram no Oriente, desde época relativamente remota, escritórios, depois consulados e finalmente embaixadas, as potências orientais (vale dizer que o autor se refere especificamente aos muçulmanos) se limitavam a enviar raras e breves missões especiais a outros lugares (2002:44). O aspecto que mais nos interessa nessa constatação do autor é a veiculação de um discurso que enfatiza a noção de liberdade de locomoção e de conhecimento como sendo uma qualidade associada ao Ocidente, conforme mostram alguns trechos de sua obra:

Negociantes ocidentais viajavam extensamente e, em geral, livremente pelos territórios muçulmanos. Negociantes do Oriente Médio não viajavam normalmente pelo Ocidente. Os muçulmanos tinham extrema relutância em se aventurar em território não-muçulmano [...] Os juristas muçulmanos discutem com certa minúcia se é permitido a um muçulmano viver num país não-muçulmano [europeu]. Consideram o caso do não-muçulmano que vive em seu próprio país, ou, em seus termos, o infiel na terra dos infiéis, que vê a luz e se converte à verdadeira fé. Pode ele permanecer onde está ou não? O consenso geral dos juristas clássicos é que não. Não é possível para um muçulmano viver uma boa vida muçulmana numa terra infiel. [...] Os muçulmanos em geral tinham pouco desejo ou estímulo para se aventurar na Europa cristã, e na verdade os doutores da Lei Sagrada proibiam em geral essas viagens, exceto para um objetivo específico e limitado. O objetivo usual - mais tarde o pretexto - era exigir 
resgate por cativos. [...] Mesmo entre o número muito pequeno de pessoas do Oriente Médio que se aventurava no Ocidente para fins de diplomacia ou comércio, uma proporção significativa não era muçulmana, pertencendo às comunidades religiosas minoritárias (LEWIS, 2002:44-46) (grifos nossos).

Como podemos entender, em todos os casos, esses enunciados remetem à noção de que o oriental muçulmano é movido exclusivamente pelos preceitos de sua crença, observação que não permite considerar a presença da racionalidade, que poderia ser manifestada, por exemplo, através de uma visão mais crítica por parte das autoridades religiosas, vistas pelo autor, segundo nossa leitura, como receptores passivos dos escritos sagrados. A posição dessas autoridades que determinam o que é melhor para seus governados (viajar para as terras dos infiéis ou não) estaria contrariando todo princípio de liberdade do indivíduo, e aqui julgamos pertinente discutir outro texto do autor no qual afirma, servindo-se de seus conhecimentos sobre o Oriente e suas línguas, que "to this day, there is no word in Arabic corresponding to 'citizen’” (LEWIS, 2005:45). Nesse artigo em que Lewis expõe sua visão sobre o conceito de liberdade e justiça no Oriente Médio de hoje, fica claro o contraste que faz entre dois mundos idealizados quando afirma categoricamente que são vários os obstáculos para o desenvolvimento de instituições democráticas naquela região, apontando como mais evidente o padrão de regra autocrática e despótica. Reconhece, no entanto, que esse padrão não encontra fundamento nem no árabe clássico nem no passado do islã, esclarecendo que o Oriente Médio teria “importado” esses modelos ditatoriais da Europa desde 1940. O autor sustenta aqui que os regimes autocráticos do Oriente Médio foram influenciados pelo fascismo, nazismo e comunismo, e essa colocação nos permite observar outro aspecto que reforça nosso argumento de que o Ocidente tem sempre investido em dar visibilidade à sua racionalidade - ou seja, enquanto a Europa teria conseguido livrar-se desses regimes que também contrariam o princípio de liberdade valorizado pelo Ocidente, o Oriente Médio teria permanecido acrítico em relação a essa realidade, resistindo a refletir sobre sua própria condição. Ao descrever os obstáculos que, segundo Lewis, dificultam a implantação da democracia "in that part of the world", o contraponto com o Ocidente se torna mais visível quando o autor acrescenta:

Another, more traditional hurdle is the absence in classical Islamic political thought and practice of the notion of citizenship, in the sense of being a free and participating member of a civic entity. This notion, with roots going back to the Greek polites, a 
member of the polis, has been central in Western civilization from antiquity to the present day. It, and the idea of the people participating not just in the choice of a ruler but in the conduct of government, is not part of traditional Islam (ibidem, p. 45).

Aqui são empregados termos como absence e not part já assumindo um pensamento político considerado como ideal (e racional) que expõe, como contraponto, uma situação totalmente oposta e que deve ser constante e legitimamente combatida. O texto estabelece com clareza uma fronteira entre uma Western civilization e os povos que vivem sob uma tradição inflexível, colocando como ponto central o aspecto da liberdade assegurada aos cidadãos de uma civilização ocidental. Aqui, novamente o autor faz questão de frisar que a palavra freedom (hurriyya, em árabe) tem sentidos diferentes para o mundo ocidental e o mundo islâmico. Referindo-se à conquista do Egito pela França em 1798, Lewis vai dizer que uma pessoa era considerada livre quando não era escrava; em outras palavras, "to be liberated, or freed, meant to be manumitted, and in the Islamic world, unlike in the Western world, 'slavery' and 'freedom' were not until recently used as metaphors for bad and good government” (p. 38). Nesse ponto torna-se inevitável considerar o aspecto do ideal de democracia norte-americano especificamente, em razão de sua condição de foco da ocidentalização e por encarnar, por meio de sua retórica política, uma forma mais atualizada de orientalismo. $\mathrm{O}$ aspecto da racionalidade é aqui também tomado como pré-requisito para que uma nação, em determinado momento histórico, possa se firmar, conforme Henry Kissinger (1994) inicia a introdução de seu Diplomacy, "with the power, the will, and the intellectual and moral impetus to shape the entire international system in accordance with its own values” (p. 17) (grifo nosso). Essas palavras precedem a afirmação do autor de que, na nova ordem mundial do século XX, coube aos Estados Unidos o papel que foi ocupado por outras potências nos séculos passados. Kissinger é enfático também quando afirma que:

No other country's population had chosen to head for a new continent and tame its wilderness in the name of freedom and prosperity for all. Thus the two approaches, the isolationist and the missionary, so contradictory on the surface, reflected a common underlying faith: that the United States possessed the world's best system of government, and that the rest of mankind could attain peace and prosperity by abandoning traditional diplomacy and adopting America's reverence for international law and democracy (p. 18). 
Como se observa, esses textos atuais que procuram, de algum modo, criar contrastes do tipo “nós” e “o resto da humanidade” abrem um diálogo com outros que foram escritos em outros momentos históricos, tendo em comum, como estamos destacando neste item do capítulo, o fato de justificarem a legitimação de suas ações de domínio e influência com a suposta ausência de racionalidade por parte de outros povos.

Espera-se que com a exposição dos itens apresentados no presente capítulo possamos melhor fundamentar a análise do corpus, apresentada no capítulo seguinte. A partir da noção de entrecruzamento de discursos, em que o enunciado, nos dizeres de Foucault (1986), desempenha sempre um papel no meio de outros enunciados (p. 114), é possível observar no filme como questões relacionadas à liberdade e ao ideal de democracia se fazem presentes. Ainda que não tratadas diretamente, ficam claras, por exemplo, no discurso liberal do personagem Anthony Hubbard, que se esforça por fazer prevalecer os direitos de todo indivíduo, incluindo até mesmo os acusados das ações terroristas da trama. A mensagem central procura criticar as formas autoritárias de governo, mesmo quando agem em nome da defesa da liberdade. No embate entre dois personagens americanos com posições diferentes (o liberal e o conservador radical), o outro (o terrorista) entra como personagem coadjuvante dentro dessa discussão; no entanto, dele não se pode prescindir, visto que é a condição pela qual o próprio discurso a favor da democracia, igualdade e liberdade possa se materializar. $\mathrm{Na}$ seção de “extras” do DVD do filme, o ator Denzel Washington, descrevendo o filme que ele protagoniza, assim o resume: “That's what the movie is about: how far do we go to protect freedom? That's the question the movie asks.” 


\section{CAPÍTULO IV - Observando os modos de silenciamento do outro em “Nova York Sitiada”}

\section{1 - Apresentação}

Na primeira parte deste capítulo, analisamos o modo como a alteridade se inscreve na seqüência de abertura de "Nova York Sitiada” argumentando que nesses instantes iniciais do filme já são anunciadas as regras que, segundo nossa leitura, orientam a maior parte do processo de construção de imagens sobre aquele que é representado como contraponto dos valores defendidos ao longo da história.

Na segunda parte, são analisados quatro trechos a partir dos quais tentamos demonstrar como as representações sobre o outro, considerando já as observações feitas na leitura da seqüência de abertura do filme, refletem não apenas na materialidade lingüística (aquilo que se constrói para o outro 'falar') como na materialidade imagética, com seus enquadramentos, ângulos e outros recursos cinematográficos que, como se sabe, são repletos de significação. Demonstramos, assim, como se dá o funcionamento do processo identitário apontado nas partes precedentes, já dentro de situações específicas nas quais se observam os aspectos que cooperam no sentido de construir uma imagem antagônica para o outro, sobretudo em situações nas quais ele precise falar ou, como veremos, se esperaria que falasse.

Na terceira e última parte, são analisados trechos cuja característica comum são representações sobre o outro que o associam, direta ou indiretamente, a seu idioma. Isso ocorre no filme em cenas nas quais o idioma do outro é nomeado e em outras onde é apenas sugerida com a exibição de caracteres árabes na paisagem de Nova York. Por meio dessa análise tentamos demonstrar o funcionamento da construção de uma identidade que se oponha àquela que deve sobressair no filme como a marca do "eu”: foco de objetividade, clareza e racionalidade.

A ordem dos trechos analisados não obedece, a rigor, a ordem em que os mesmos estão inseridos no filme, visto que esse critério não traria ganhos para o trabalho dentro do que nos propomos realizar. Os trechos são assim ordenados dentro de um critério estabelecido pela própria análise, em uma tentativa de aproximar os temas de maneira que os aspectos observados possam ser melhor compreendidos. Deve ficar claro que não é feita uma análise do filme e sim de trechos (aqui entendidos como seqüências discursivas) que, no seu conjunto, compõem o recorte realizado. 


\section{2 - Um corpo silente (mas presente) na seqüência de abertura}

Antes de iniciarmos a análise, gostaríamos de retomar brevemente o objetivo desta leitura lembrando que nos concentramos na inscrição do outro sob o ponto de vista do espaço destinado ao seu dizer, aqui entendido como uma oportunidade que esse personagem teria para se expressar sobretudo verbalmente, até porque o filme comercial hollywoodiano se caracteriza pela centralidade desse tipo de linguagem. Essa alteridade é personificada no filme através de vários personagens que possuem em comum o fato de pertencerem à mesma etnia, falarem a mesma língua e compartilharem a mesma crença. Esses personagens são aqui tratados conjuntamente uma vez que o trabalho não visa ao estudo da individualidade dos participantes da trama, e sim a tratar especificamente de sua inscrição sob o aspecto mais geral da destinação de espaço para o dizer. O mesmo se aplica em relação aos personagens que são identificados na trama como americanos, aos quais nos referimos com certa freqüência como “eu” ao longo do texto. É verdade que, em certos casos, será necessário expor algumas considerações em relação ao personagem envolvido no trecho analisado, mas a análise não é centrada no personagem. Do lado da alteridade, vale dizer, nem todos os personagens são nomeados na trama, diferentemente do que ocorre com os personagens americanos, mas entre os que são destacamos o líder religioso xeique Ahmed Bin Talal (presente somente na seqüência de abertura), Khalil Saleh, Samir Bouajila e Tariq Hussein.

Ao mostrarem imagens do atentado contra as Torres Khobar, em Dhahran (Arábia Saudita), em 1996, as primeiras cenas da seqüência de abertura atualizam um acontecimento e acionam uma memória discursiva de outros episódios relacionados a ataques terroristas. Além de conferirem uma qualidade de verossimilhança à obra, tão cara aos produtores de Hollywood, essas imagens se prestam como um ponto de partida fundamental para a narrativa de uma história a ser contada em um momento histórico específico, marcado pela necessidade do então governo Clinton de demonstrar reação contra os ataques terroristas sofridos durante sua administração ${ }^{32}$. Realizar tal projeto por meio de um filme inevitavelmente implica comprometer-se com as convenções e características da indústria cinematográfica, que lida sobretudo com a fantasia, o extraordinário. Como concluem Bastos e Santos (2006),

\footnotetext{
32 O ex-presidente Bill Clinton (1993-2001) costuma ser criticado quanto à política que adotou em relação ao terrorismo. Analistas que defendem uma postura mais vigorosa (nos moldes de George W. Bush) propõem que Clinton teria sido complacente em sua reação contra atentados importantes ocorridos durante seu governo, como o primeiro ataque ao World Trade Center (1993), o atentado contra as Torres Khobar, em Dhahran (1996) e os ataques contra as embaixadas norte-americanas no Quênia e na Tanzânia (1998).
} 
“contamos estórias porque elas fogem ao canônico, ao que é comum” (p. 224), e esse ato de contá-las parece exigir invariavelmente que acrescentemos “algo novo” ao que já se sabe. O próprio cinema tem sido um meio pelo qual esses saberes vão se instituindo e se acumulando, como provam os inúmeros estudos existentes que problematizam, por exemplo, a demonização de certos tipos de personagens já retratados por Hollywood. O algo novo que buscamos com a análise dessa seqüência de abertura está relacionado ao aspecto da montagem dessas cenas iniciais, uma vez que esta pode revelar mais do que a visão imediata da imagem isolada (ou o fotograma) do outro na cena, aqui encarnado pela figura do líder religioso xeique Ahmed Bin Talal (FIGURA 8). Ainda que a imagem em si do personagem na seqüência de abertura já apresente aspectos relevantes a serem analisados (como veremos adiante), é a sua posição na narrativa da montagem na qual esses planos se inserem que pode revelar a(s) discursividade(s) colocada(s) em jogo com a emergência do sujeito que comanda essa representação. Segundo Nichols (1981), "narrative shares with ideology a set of structural mechanisms serving to generate apparent unity and coherence [...] it provides the sense of an ending” (p.78), e é essa tentativa de tornar compreensível a união dos fragmentos da montagem que interessa observar a propósito da leitura dessa seqüência de abertura. A idéia de montagem nos permitirá também mobilizar um conceito fundamental de Pêcheux (1988) acerca do sentido, não obstante lidarmos com a imagem aqui especificamente, à primeira vista distante do principal objeto de estudo do autor, que é a palavra. Estamos tomando a liberdade de tomar os dois instantes de et cetera na citação de Pêcheux como uma possibilidade de acrescentarmos a idéia de imagem à sua teorização, segundo a qual:

[O] sentido de uma palavra, de uma expressão, de uma proposição, etc., não existe “em si mesmo” (isto é, em sua relação transparente com a literalidade do significante), mas, ao contrário, é determinado pelas posições ideológicas que estão em jogo no processo sócio-histórico no qual as palavras, expressões e proposições são produzidas (isto é, reproduzidas). Poderíamos resumir essa tese dizendo: as palavras, expressões, proposições, etc., mudam de sentido segundo as posições sustentadas por aqueles que as empregam, o que quer dizer que elas adquirem seu sentido em referência a essas posições [...] (p. 160) (grifos do autor). 

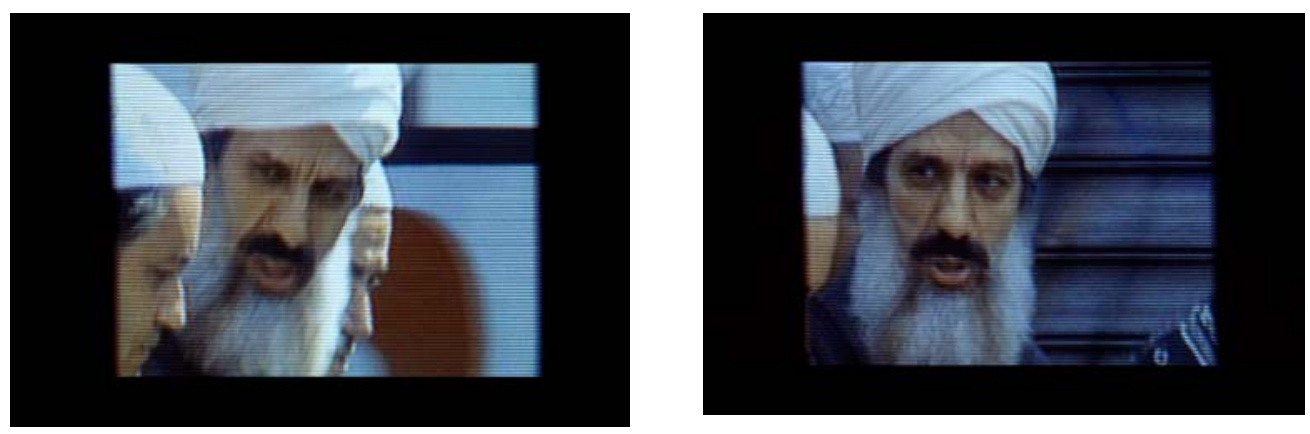

Figura 8: Imagens do personagem Ahmed Bin Talal

Ora, a imagem isolada do xeique pode ser interpretada, evidentemente, como a representação de um fanático religioso (considerando o contexto criado pelo filme) ou ícone de uma cultura não ocidental, a julgar pelo vestuário e fisionomia; todavia a montagem faz com que essa enunciação, permitindo-nos o corolário, seja única, uma vez que estão em jogo posições ideológicas específicas. A montagem nos permite questionar, por exemplo, por que essa seqüência de cenas e não outra, por que esses efeitos sonoros e não outros, por que a escolha desses fragmentos de imagens de arquivo e não outros. Todos esses elementos revelam a interpelação do indivíduo em sujeito pela ideologia e reforçam a idéia de opacidade da imagem, contrariando o investimento do cinema em conferir transparência à mesma. Há aqui um produto finalizado que resulta da intervenção de diferentes profissionais além de roteiristas, diretores e atores, já que o material bruto gravado é submetido a editores e especialistas em efeitos especiais, os quais também imprimem sua marca ideológica ao material com o qual devem lidar.

Antes de dirigirmos a atenção ao aspecto privilegiado na análise, importa recorrermos àquilo que Eisenstein (1990) diz sobre o conceito de montagem cinematográfica, já que a tomamos como fundamental nesse primeiro instante do estudo. O autor ressalta o valor da justaposição de fragmentos em uma montagem esclarecendo que, ao colocarmos juntos dois pedaços de filme quaisquer, estamos inevitavelmente criando "um novo conceito, uma nova qualidade, que surge da justaposição” (p. 14). Ele não deixa de acrescentar, no entanto, que tal característica não é exclusividade do cinema, visto se tratar de um fenômeno que ocorre toda vez que justapomos dois fatos, dois fenômenos, dois objetos (ibidem). Uma vez inserido em uma montagem, o fragmento inicial deixa de existir como algo não relacionado, tornando-se a partir de então uma "representação particular do tema geral, que penetra igualmente todos os fotogramas” (ibidem, p. 17). É possível, a nosso ver, estabelecer uma relação dessa teorização com o que propõe Pêcheux mais acima, pois, ainda que de um lugar diferente do da lingüística, o que parece ficar subentendido em Eisenstein é que um "pedaço" de filme (equivalente a uma palavra, expressão, proposição, como pretendemos) pode apresentar 
outros sentidos dependendo do que se fizer com esse fragmento, do momento histórico em que se fizer isso e, evidentemente, de quem o fizer.

Podemos agora observar melhor como se dá a entrada do outro no filme como um personagem a quem sempre se restringirá, de algum modo, o espaço destinado ao seu dizer, movimento que dá ocasião também à análise do aspecto da língua com a qual esse outro é identificado, já que esta é considerada, como lembram Stam e Shohat (1997), um "potente símbolo de identidade coletiva” (p. 191). Pois bem, já no início do filme Ahmed Bin Talal é inscrito na condição de responsável pela explosão do alojamento militar na Arábia Saudita, e é possível notar o cuidado dos idealizadores com a montagem dessas cenas introdutórias se atentarmos para o aspecto do tempo que elas ocupam dentro do longa-metragem, aproximadamente três minutos e cinco segundos. Situações que diferem umas das outras, por exemplo, no nível da imagem, são aqui organizadas tendo como elemento unificador a trilha sonora, a qual confere coerência à narrativa por permear todos os fragmentos, ainda que variando quanto à modulação. Antes de prosseguirmos com a análise, apresentamos abaixo uma descrição resumida dos elementos imagéticos e sonoros que julgamos mais relevantes para a análise da seqüência de abertura de “Nova York Sitiada”. Também disponibilizamos acesso à cópia dos trechos que são analisados através de um menu disponível na versão eletrônica do arquivo que remete a um programa que exibe as imagens.

\section{SD1}

\section{CENA 1 (20 segundos)}

\section{O que se vê}

Em fade in, aos poucos vai sendo exibida a fachada de um edifício de oito andares* destruída após uma explosão. Equipes de resgate carregam os corpos das vítimas.

\section{O que se ouve}

Vozes em off de diferentes repórteres relatam o episódio. Essas vozes se antecipam ao fade in das imagens: The U.S. military presence abroad was rocked today when a bomb exploded... [...] A bomb exploded in the army barracks in Dhahran, Saudi Arabia. [...] A multinational force... [...] Ripped the front of the eight-story military dorm, exposing just how vulnerable U.S. troops are here. [...] And marines on duty seem, for the most part, numbed by the horror of the morning bombing.

* Esse local não cenográfico servia de fato como alojamento militar americano em Dhahran, Arábia Saudita.

\section{CENA 2 (6 segundos)}

\section{O que se vê}

Aparição do personagem xeique Ahmed Bin Talal caminhando com seus seguidores. Vemos que conversam entre si, pois o movimento dos lábios indica essa ação. Ao final da cena, congela-se a imagem com close no rosto do xeique por quatro segundos.

\section{O que se ouve}

Voz em off de repórter: Primary indications suggest this to be the work of Sheik Ahmed Bin Talal, a radical fundamentalist cleric known to have issued a fatwa... (fade out).

Fundo de música instrumental árabe. 
CENA 3 (7 segundos)

\section{O que se vê}

Aparição do então presidente Bill Clinton em um trecho de seu pronunciamento por ocasião do atentado de 1996 em Dhahran.

\section{O que se ouve}

Bill Clinton: The explosion appears to be the work of terrorists, and if that is the case, like all Americans, I am outraged by it.

Fundo de música instrumental árabe.

\section{CENA 4 (1m24s)}

\section{O que se vê}

Deserto visto à distância. Aos poucos, com a aproximação, vemos um carro viajando pelas dunas, o único objeto móvel na paisagem. Em seguida, vemos em primeiro plano o xeique no interior do veículo apenas contemplando a paisagem. Usa trajes diferentes dos da Cena 2.

O que se ouve

Fundo de música instrumental árabe. Aos poucos se intensifica com a inclusão de voz humana.

\section{CENA 5 (4 segundos)}

\section{O que vê}

Reaparição de Bill Clinton e continuação do pronunciamento.

\section{O que se ouve}

Bill Clinton: The cowards who committed this murderous act must not go unpunished.

Fundo de música instrumental árabe.

\section{CENA $6(1 \mathrm{~m} 57 \mathrm{~s})$}

\section{O que se vê}

Continuação da cena do deserto. Tela de computador mostra o trajeto do veículo, rastreado por satélites. Este cruza com um homem que conduz dois camelos no sentido contrário. O veículo é impedido de prosseguir mais adiante ao se aproximar de um bando de cabras conduzido por dois pastores. Em primeiro plano, vemos o xeique silente e contemplativo no banco traseiro. Os pastores (agentes disfarçados, na verdade) põem em execução o plano de captura do xeique, retirando suas metralhadoras de um esconderijo. As cabras ocupam todo o espaço da tela. O veículo é mostrado depois todo perfurado e com marcas de sangue no vidro. Vemos o motorista morto.

O que se ouve

Vozes em off dos controladores da operação: Sand Leader, this is Eagle Eye. We have a fix on the package. It is in a Mercedes sedan traveling south... [...] Com-sat One, your coordinates are as follows: 1-8-0-5. [...] Package is approaching target area. Estimated time of contact is approximately 14 seconds.

Poucas palavras em árabe ditas pelo xeique, buzina e gritos do motorista dirigidos aos dois pastores.

Ruídos de disparos de metralhadoras se confundem com os sons emitidos pelas cabras.

Fundo de música instrumental árabe.

\section{CENA 7 (5 segundos)}

\section{O que se vê}

Continuação do pronunciamento de Bill Clinton.

O que se ouve

Bill Clinton (voz em off): Let me say again. America takes care of our own. Those who did it must not go unpunished.

Fundo de música instrumental árabe. 


\section{O que se vê}

O xeique é encapuzado e levado pelos agentes disfarçados de pastores. Grande explosão destrói o veículo completamente.

\section{O que se ouve}

Voz em off do controlador da operação: Eagle Eye, this is Sand Leader. The sheik is in our custody. [ruído da explosão do carro] He is alive and well, and will be delivered intact by 8:00 tomorrow.

Fundo de música instrumental árabe.

\section{CENA 9 (26 segundos)}

\section{O que se vê}

Close no rosto do xeique já na prisão. A câmera se move e o mostra do alto, sentado e movimentando as contas do tasbi* enquanto realiza sua oração. Aparição do personagem William Devereaux (Bruce Willis) caminhando lentamente e observando o cativo. O xeique permanece sentado durante toda a cena, indiferente à presença daquele. Não interrompe sua oração em momento algum. Usa vestes diferentes das vistas anteriormente. Fade out da imagem.

\section{O que se ouve}

Oração em forma de cântico do personagem Ahmed Bin Talal.

Fundo de música instrumental árabe.

* Espécie de rosário utilizado pelos muçulmanos enquanto realizam suas orações.

\section{CENA 10}

\section{O que se vê}

Fade in com os caracteres do título do filme na tela: THE SIEGE.

\section{O que se ouve}

Fundo musical diferente e metalizado anuncia as cenas posteriores, cujo local já será Nova York.

Para compreender como se dá a inscrição do outro na Cena 2 como aquele cujo dizer deve ser representado como não-desejável, é necessário observar os sentidos produzidos pela profusão de vozes de repórteres que, nas Cenas 1 e 2, dão sustentação às imagens da destruição provocada pela explosão. Dominando todo o espaço reservado à linguagem verbal dessas cenas, essas vozes de repórteres relatam insistentemente o ocorrido, enfatizando a agressão em si e privilegiando, como se pode prever, apenas o ponto de vista do agredido. Assim, já nos instantes primeiros do filme podemos observar o fenômeno apontado por Osakabe (2002), segundo o qual aquele que enuncia já é, "no momento específico em que enuncia, a entidade dominante, na medida em que é ela quem manipula as coordenadas do discurso" (p. 70). Esse instante equivale àquele no qual a entidade com o "poder de narrar" pode impedir, como bem lembra Said (1999), “que se formem e surjam outras narrativas” (p. 13). Como se observa, as vozes dos repórteres se antecipam até mesmo à exibição das primeiras imagens do filme, em um típico caso de "authoritative voice of a narrator who identifies and interprets the images” (KRESS e VAN LEEUWEN, 2001:17). A fusão das imagens de destruição de um fato histórico de 1996 com as palavras dos repórteres reforça, dentro da seqüência de planos da montagem, a representação sobre o outro com uma 
característica diferente daquela que remete, na superficialidade imagética, à típica imagem do xeique árabe quando de sua aparição na Cena 2. Como vimos no Capítulo 2, o sentido da imagem do muçulmano passa a ser determinado por posições ideológicas muito específicas a partir dos anos 1970, e a seqüência de abertura do filme atualiza essa determinação ao mostrar, antes da aparição dessa imagem com seu posterior congelamento, o resultado catastrófico da ação de quem age movido por um fundamentalismo religioso. Inscrito desde o início como um criminoso covarde (the cowards who committed this murderous act) e silenciado pela profusão de imagens e dizeres que expressam a estupefação do agredido, o acusado não possui no filme um espaço para apresentar algum tipo de defesa, sobretudo porque seu único momento de dizer dentro da seqüência de abertura também é silenciado por meio de um tipo de elipse. Na Cena 2, como descrevemos, sabe-se que o xeique conversa com seus seguidores porque o movimento de seus lábios e as expressões sugerem tal ação, porém não se trata de um dizer que possa ser considerado válido, da maneira como ocorre com as palavras dos repórteres (Cenas 1 e 2), de Bill Clinton (Cenas 3, 5 e 7) e dos controladores da operação de captura no deserto (Cenas 6 e 8). Se essa elipse do som pode se justificar pelo tipo de situação criada (um objeto mostrado à distância por uma suposta câmera de televisão remota que não captaria o áudio da conversa), a mesma revela também o aspecto ideológico da construção, qual seja, o desinteresse em mostrar alguns elementos da identidade do representado, como sua língua, sua voz e, sobretudo, seu dizer. A análise da imagem do xeique, tomada isoladamente, não traria tanto à tona o sujeito ideológico por trás dessas representações, visto que o sentido poderia estacionar na questão já conhecida do estereótipo. O modo de perceber o outro como possuidor de um dizer desprovido de valor por parte desse sujeito se torna mais visível na análise a partir da justaposição dos fragmentos que compõem a montagem. No seu conjunto, produzem um discurso sobre o outro que parece sugerir que a não acessibilidade a suas idéias nos moldes “transparentes” ocidentais justifique uma constante vigilância por parte de quem se sinta ameaçado. A inscrição não-histórica do outro e sua condição pressuposta de culpado já na abertura do filme se tornam, assim, o argumento necessário para as ações posteriores atribuídas a células de terroristas que teriam se instalado em Nova York como uma reação à prisão de seu principal líder religioso.

Ainda que não surpreenda a constatação de que o espaço dessa narrativa é ocupado em toda sua extensão pela defesa e ênfase do ponto de vista do agredido, visto que essa retórica é própria do discurso dominante em seus constantes esforços de justificar tomadas de decisão, interessa atentar para os meios técnicos empregados para garantir a naturalização dessas representações no filme. Como bem resume Nichols (1981) a propósito de como funciona o 
processo de perpetuação de um determinado conceito, "ideology uses the fabrication of images and processes of representation to persuade us that how things are is how they ought to be” (p. 1). Em “Nova York Sitiada”, essa “fabricação” é particularmente relevante, sob o ponto de vista ideológico, visto que os efeitos de sentido produzidos pelas imagens acabam se sobrepondo à mensagem liberal que o filme procura de algum modo transmitir, qual seja, a condenação de métodos segregativos, hostis e anti-democráticos na resolução de um conflito de tal natureza. Até atingir os instantes finais do filme, quando o personagem de postura liberal Anthony Hubbard (Denzel Washington) derrota as medidas discriminatórias de William Devereaux (Bruce Willis) contra imigrantes árabes residentes em Nova York, todas as imagens que exibem ou fazem referência ao outro insistem na representação sobre o mesmo como silente, indiferente, violento e indisposto ao diálogo. A suposta crítica do filme a um regime de governo belicoso acaba se tornando questionável quanto a sua "verdade" diante dos efeitos de sentido produzidos (ou as outras mensagens) a partir das imagens e operações lingüísticas.

Observamos também que, ainda que o sujeito que comanda essas representações venha à tona revelando um modo de perceber o dizer do outro como despossuído de valor, o mesmo não pode prescindir do aspecto corpóreo dessa alteridade - ou seja, o outro precisa ser mostrado fisicamente (um corpo silente que deve estar presente). Esse movimento nos apresenta outras possibilidades de análise dentro do recorte realizado. Mostrado de perfil na Cena 2, o olhar oblíquo de Bin Talal (FIGURA 8) não é tomado como fonte de autoridade na hierarquia de valores implícita no filme; dito de outro modo, sua imagem e seu olhar são sempre objeto do olhar de outro (e aqui o espectador poderia estar incluído), como fica também demonstrado na representação dessa sua aparição como imagem capturada por uma câmera de reportagem, aparentemente sem o conhecimento da pessoa filmada. Esse corpo em movimento cujo dizer é negligenciado e elidido não poderia ser mostrado no filme sem a autoridade da "voz do narrador" (KRESS e VAN LEEUWEN, op. cit.), papel que cabe à repórter que, na Cena 2, o descreve como "a radical fundamentalist cleric known to have issued a fatwa [fade out]...”, procurando talvez fixar um sentido único à imagem mostrada e congelada por alguns segundos, qual seja, o de sua vinculação à barbárie desmedida e da impossibilidade de que possa advir algum tipo de negociação diplomática com quem é desde sempre definido como fundamentalista e radical. O "status" do outro fica definido a priori 
como inferior, passageiro e (até que desapareça) ilegítimo (BAUMAN ${ }^{33}$ apud WAGNER, 1997:86).

Diferentemente da inscrição do outro na narrativa, marcada pela artificialidade do congelamento de imagem e pela ausência de palavras que possam ser ouvidas, a entrada do então presidente Bill Clinton, ainda que súbita após um corte do close do rosto congelado do xeique (em uma representação do contraste de dois tipos de liderança), ocorre dentro de uma seqüência de eventos mais inteligível, do ponto de vista da clareza proporcionada ao telespectador do filme comercial pelo uso da linguagem verbal. As falas dos repórteres descrevendo o episódio seguidas da nomeação do suposto culpado e da descrição de sua personalidade de algum modo preparam o espectador para a aparição de um político da vida real no filme. As três cenas nas quais Clinton participa da narrativa possuem em comum o fato de que o mesmo faz referência a uma terceira pessoa - “terrorists” (Cena 3), "the cowards" (Cena 5) e "those who did it” (Cena 7) - todavia, como temos mostrado, ao outro não é destinado um espaço para apresentar o “seu” argumento.

O trecho da montagem que inclui as Cenas 3-7 põe em cena um diálogo entre dois níveis de interlocutores: de um lado, aquele para quem a objetividade do dizer é um valor a ser reafirmado e, de outro, aquele que, oculto na obliqüidade de sua aparição, valoriza a obscuridade. Enquanto Bill Clinton fala de um lugar identificado e reconhecido, como mostram as palavras The White House ao fundo (FIGURA 9), o interlocutor criado na montagem é representado como fugitivo silente em um deserto. O olhar de Clinton, ainda que não dirigido ao espectador completamente, detém o ponto de vista, em contraste com o olhar indiferente do xeique que parece apenas contemplar a paisagem do deserto (FIGURA 10). Na Cena 4, é possível notar a ênfase dada à ausência de palavras atribuída ao outro se considerarmos a duração da mesma (1m24s), um tempo significativo dentro da economia de um filme hollywoodiano. Mostrado em primeiro plano no banco traseiro do veículo (Cena 6), o olhar de Ahmed Bin Talal (FIGURA 10) é novamente representado como esquivo, sem a exibição de elementos significativos que possam produzir o processo de imersão do espectador na cena - ou seja, não se criam meios para que este possa auscultar o pensamento de Bin Talal e, em algum momento, identificar-se com o mesmo. Situação oposta ocorre na Cena 9, em que o silêncio do personagem William Devereaux (Bruce Willis) não impede a imersão do espectador, o qual é convidado, por meio do trabalho de câmera, a ver exatamente o objeto que os olhos do general também observam de uma posição espacial superior, que é a

\footnotetext{
${ }^{33}$ BAUMAN, Z. Intimations of postmodernity. Londres: Routledge, 1992, p. xxvi, apud WAGNER (op. cit, p. 86).
} 
imagem rebaixada do xeique cativo, indefeso e indiferente a tudo que se desenvolve no ambiente, apenas se importando com sua oração (FIGURA 11).

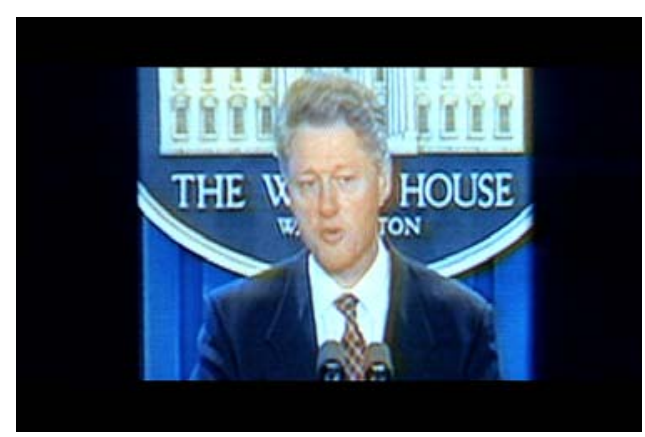

Figura 9

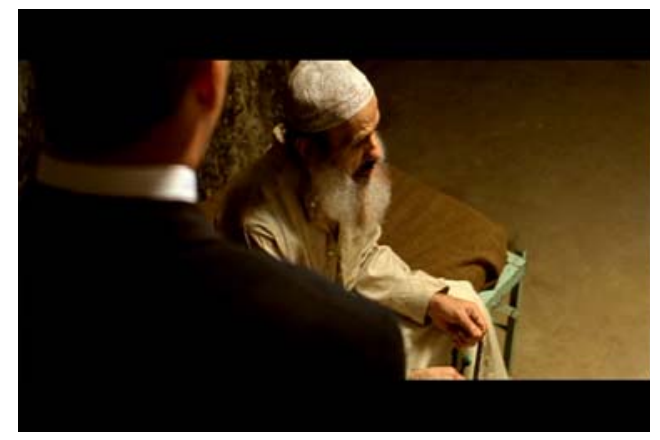

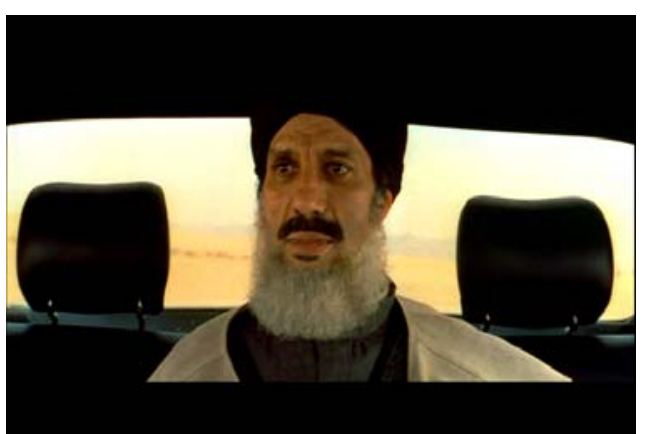

Figura 10

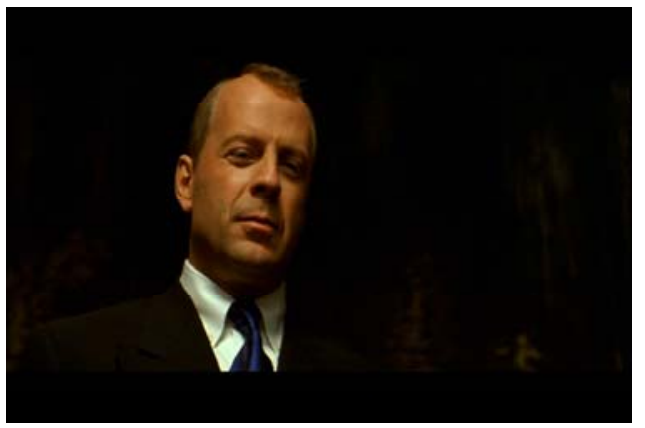

Figura 11

Na Cena 6, também considerando a centralidade da linguagem verbal no filme, é possível argumentar que as vozes dos controladores da operação de captura no deserto também cumprem o papel de ocupar o espaço destinado à manifestação do ponto de vista do agredido, o qual, diante do consentimento do réu com o silêncio que lhe é imposto, tem justificada a operação de captura, a despeito de seu grau de violência.

Concluindo a análise da seqüência de abertura do filme, invocamos mais uma vez Eisenstein no ponto em que o autor acrescenta que a justaposição de fragmentos em uma montagem não é um fenômeno restrito ao cinema, o que equivaleria a dizer que, de algum modo, todos cumprem um papel de editor em suas narrativas da vida cotidiana, mesmo sem se darem conta dessas escolhas, e todos o fazem de acordo com aquilo que os constitui ideologicamente, em um entrecruzamento constante de discursos. Na seqüência de abertura do filme também é possível observar um entrecruzamento de discursos que revela essa constituição ideológica do sujeito. Assim, temos o discurso sobre o repúdio ao fundamentalismo religioso na Cena 2, o discurso sobre a necessidade da ação anti-terrorismo 
e discurso sobre a união dos americanos na Cena 3, e o discurso sobre a auto-suficiência norte-americana na Cena 7. O conhecimento a partir da leitura realizada até aqui das representações sobre o outro na seqüência de abertura será fundamental para que possamos, daqui em diante, analisar os trechos que fazem parte, no sentido mais estrito do termo, da trama do filme propriamente dita. Enquanto filme de ação, caracterizado por movimentos freqüentes, diálogos entre os personagens, cenas externas e internas, "Nova York Sitiada” só inicia efetivamente após a aparição dos caracteres do título na tela, conforme nossa descrição da Cena 10 - ou seja, o início do filme coincide com o final da extensa seqüência de abertura.

\title{
4.3 - Representações da ininteligibilidade das palavras do outro
}

Iniciamos esta segunda parte da análise definindo um critério para a leitura dos trechos que serão abordados, dada a especificidade de um corpus fílmico. Pois bem, na análise, atribuimos o comando de todo o trabalho de construção do filme (orientação da câmera, montagem, sonorização, cenários, atores, diálogos) a uma instância doadora ${ }^{34}$ que narra a história e que pode ser concebida como uma "hiperpersonagem invisível e inaudível" (MACHADO, 2007:110). Esse é o sujeito que enuncia a narração do filme e apresenta o seu discurso. Por essa razão, e em função da limitação do trabalho, não nos interessará aprofundarmo-nos em análises de aspectos psicológicos de cada personagem em questão porque:

\begin{abstract}
Enquanto as visões das personagens conservam a sua própria integridade, é o lugar do narrador que as exibe como visões e que nos faz vê-las como parte de um amplo quadro, graças ao poder de seu comentário. Ou seja, o narrador é relacionado às personagens ao mesmo tempo através das estruturas de analogia (ele pode apropriar-se de seus olhares) e de independência (ele pode mostrar suas visões como simples visões) (BROWNE ${ }^{35}$ apud MACHADO, 2007:84-85).
\end{abstract}

\footnotetext{
${ }^{34}$ Esse termo é aqui utilizado com o mesmo sentido que é empregado nos estudos do texto literário (instância ou dimensão que produz o texto, que o disponibiliza, que o entrega, que o doa). A "instância doadora", no estudo cinematográfico, se refere à dimensão que dá a ver a cena, por exemplo, no trabalho de câmera, no enquadramento, nos efeitos especiais, etc.

${ }^{35}$ BROWNE, N. Narrative point of view: the rhetoric of Au Hasard, Balthazar, in: Film Quarterly, v. XXXI, $n^{0}$ 1, fall, 1977.
} 
O que importa notar a partir do exposto é que existe uma instância maior, um hiperpersonagem não visível no filme, que se encarrega de conduzir uma narrativa apresentada na forma de diálogo, no qual ele não “intervém”. A “voz” desse narrador no tipo de filme analisado não se mistura às dos personagens em um discurso indireto. Ressaltemos, no entanto, que, esse narrador não é aqui pensado de maneira psicologizante, como se pudéssemos relacionar diretamente a história à intenção de quem a está contando. Sob a ótica da Análise do Discurso que, desde as formulações iniciais de Michel Pêcheux, entende o sujeito como socialmente estruturado e "não tomado em sua condição lingüística e/ou individual” (INDURSKY, 2000:70), o narrador a que nos referimos é o sujeito tal como existe socialmente e interpelado pela ideologia (BRANDÃO, 2004:110).

Assim, para distinguirmos ao longo do texto aquele cujos modos de dizer nos propomos a analisar mais detidamente daquele que entendemos como essa instância doadora que conduz a narrativa comandando os procedimentos de leitura a ser incorporada pelo espectador, referimo-nos ao primeiro como “outro" e ao segundo como narrador ou “eu”, este entendido como o lugar de onde se fala e o ponto de vista privilegiado na história. Evidentemente, em nenhum dos casos pressupomos qualquer noção de unidade, visto que a dispersão é tomada como constitutiva de todo sujeito do discurso.

Julgamos também relevante apresentar, em caráter introdutório, um resumo do perfil de cada um dos principais personagens envolvidos nas situações analisadas nesta parte do trabalho, ainda que sem nos aprofundarmos em questões psicológicas.

- Anthony Hubbard (Denzel Washington): agente oficial do FBI que atua na liderança das operações de busca dos suspeitos de envolvimento nos atentados. É movido por fortes ideais característicos de uma postura liberal. Defende com determinação um tratamento humano e digno àqueles que precisam ser interrogados e coloca-se firmemente contrário à idéia que dá título ao filme - ou seja, opõe-se à declaração de lei marcial em Nova York e ao estado de sítio que essa resolução implica. Esforça-se por solucionar o conflito unicamente através do diálogo e do cumprimento das leis nacionais.

- Elise Kraft / Sharon Bridger (Anette Benning): oficial da CIA que já atuou em importantes missões no Oriente Médio e que possui amplo conhecimento sobre a cultura dessa região, dominando, inclusive, o idioma árabe. Mantém vínculos afetivos com Samir Nazhde (Sami Bouajila), um professor de árabe em uma universidade de 
- Khalil Saleh (Aasif Mandvi): um dos suspeitos de envolvimento na série de atentados na cidade. Nas situações em que fala inglês, apresenta certa dificuldade. Não se sabe se possui cidadania norte-americana. Poucas informações são fornecidas a respeito do personagem nas cenas das quais participa. Uma das cenas mostra que possui algum vínculo com Samir Nazhde (ambos são mostrados conversando afetuosamente), mas o som do diálogo é totalmente elidido.

- Frank Haddad (Tony Shalhoub): agente do FBI e principal assistente de Anthony Hubbard. De origem árabe, possui cidadania norte-americana, e se mostra plenamente adaptado ao estilo de vida do país em que vive. Sua figura na equipe se torna fundamental a partir do instante em que cumpre o papel de intérprete nas situações em que Hubbard deve interagir com os supostos terroristas. Sua origem apenas se torna um problema no filme quando, já colocada em prática a medida dos militares que inclui o estado de sítio, passa a criticar severamente o tratamento que "seu povo" começa a receber desde então, sobretudo porque seu filho adolescente também é detido no campo de concentração improvisado na cidade.

\subsection{1 - “Bombers of Bus 87”: A força como única linguagem}

Consideramos a primeira seqüência discursiva que analisamos nesta parte um dos momentos do filme mais emblemáticos do tipo de representação sobre os modos de dizer do outro que o trabalho tem procurado demonstrar. Nenhum som que pudesse ser produzido por esse outro é ouvido ao longo do trecho e ele tampouco chega a ser mostrado corporeamente. Sabe-se que ele existe e que está presente na realidade criada pelo filme em virtude da concretude imagética e sonora de seu ato. Essa seqüência de cenas se situa em um momento de grande tensão no filme, especialmente devido aos esforços da produção no sentido de conferir o maior grau possível de autenticidade às imagens.

SD2

Contexto: Hubbard, Frank e Elise, após serem informados sobre a ameaça de explosão de um ônibus no Brooklyn, chegam ao local e ali se deparam com uma multidão de policiais, bombeiros e 
repórteres com todo aparato, viaturas e helicópteros. Um ônibus com todos os passageiros a bordo está estacionado no meio da rua. Hubbard é informado de que três homens dominaram o motorista e todos os passageiros são mantidos reféns. Tendo sido informado de que o especialista em negociações não chegará a tempo, Hubbard toma a iniciativa de tentar conversar com os seqüestradores por telefone com o auxílio lingüístico de Frank Haddad. Consegue convencer os terroristas a libertarem as crianças e, encorajado pelo êxito inicial, tenta convencê-los a libertarem também os idosos. Após algum tempo, a porta do ônibus se abre e os idosos aparecem. Hubbard se anima, porém nem chega a concluir sua frase de agradecimento aos terroristas porque todos são surpreendidos pela explosão do ônibus, que mata os idosos e todos quantos estavam no veículo.

Policial: Three men, definitely armed, and this time they're still on the bus.

Hubbard: So no communication of any kind?

Policial: No, no, it's weird. They're just in there.

Hubbard: Just in there. Okay. See if you can get the frequency of the bus driver's radio. We'll try and get him on the phone. Frank. [...] Get a couple of dat phones, okay? Make sure they're secure portables.

Frank: Perfect. The negotiator's on his way.

Hubbard: A couple of techies, too, Frank. We want sound.

Policial: Sir. There's children on that bus. We counted about six.

Hubbard: That gives us something to work with, then, doesn't it?

Elise: What's happening out there? [...] They've taken another bus, haven't they? Hey, talk to me.

Hubbard: You want to talk now. You want me to be your friend now. Is that it?

Elise: Listen. These guys are the real deal.

Hubbard: Are they? How do you know? Is there a terrorist cell operating in Brooklyn? [...] The blue bus, was that a warning?

Elise: Yes, and I'm afraid they're gonna blow this one.

Hubbard: How do you know they're gonna blow the bus if they haven't blown it already? [...]

Elise: They haven't asked for anything, have they?

Frank: The driver's name is Larry Kaiser. He says they've got explosives strapped to their chests, they've got automatic weapons, and he thinks they're speaking Arabic.

Hubbard: Where the hell is the negotiator?

Frank: The tunnels got twenty minute delays. They're working on both bridges.

Hubbard: Okay, did he say anything else about the device? Did he describe it anyway? Did he talk about cords or buttons or anything?

Frank: No. He didn't say.

Elise: Oh, God. They're not here to negotiate. [...] They were waiting for the cameras. They want everybody watching. You've got the shooters in place? [...] Use them. Kill them now. Look, it's lose- 
lose anyway you play it. You want to lose little or lose big? [...]

Hubbard: Let me have the phone... Hello, Larry. This is Agent Hubbard, FBI. I'm gonna be negotiating our way out of this. Yes, we got somebody here who can translate, but you gotta remain calm. All right. Put them on the phone... Hello, sir. My name is Anthony. [intérprete] I want you to know right from the start I'm not the boss. [interpréte] I don't have the authority to negotiate any deals or to respond to any demands. [intérprete] You need anything in there? Any medical supplies? Anybody need any help? [intérprete]

Frank: I don't even know if they understand.

Hubbard: Look, I know you may not want to talk to me, but are you willing to listen to me? [intérprete] Whatever grievances you have, whatever quarrels, surely it doesn't involve these children. [intérprete] I'm asking you, please, would you please let the children go? [intérprete] Please. [intérprete] Thank you. Thank you very much. I appreciate your gesture. The best way to get what you want in this situation is to show yourself to be reasonable, which you have done. I appreciate that. I really do. [...] Now we got some more to talk about. As you can see, I'm unarmed. I have no weapons. And what I propose... is that you let these people go... and I'll take their place. This way you don't have to worry about pizza deliveries or people running back and forth to the bathroom or anything like that. [intérprete] And I guarantee you that the police department, FBI, everybody, they'll disappear. You look out your window now, you'll see the helicopters are already moving out. I'm gonna take your silence to mean that you're considering my offer. I'll tell you what. Why don't you just let the elderly people go? [intérprete] You know these old people. They've been standing up there for a long time. Why not just let them go? [intérprete]

Thank you very much. Now we just...

Considerando a lógica da centralidade da linguagem verbal e direta, bem como do recurso de imagens não ambíguas privilegiadas nesse filme (característica dos filmes comerciais que não se preocupam, em termos de estética, com linguagens mais introspectivas), a presença do outro, a qual é vital para a narrativa, se caracteriza justamente por sua ausência, visual e sonora. A postura contrária ao diálogo atribuída ao outro é anunciada logo no início do trecho quando Hubbard é informado de que os seqüestradores não estão mantendo qualquer tipo de contato (no communication of any kind) - ou seja, nenhum dos supostos seqüestradores aceita negociar ou esclarecer os motivos de sua ação. A mudez do outro intervém, assim, como um problema a ser resolvido pelo eu e se torna, portanto, um acontecimento que passa a reclamar sentidos. O termo “weird” empregado para descrever tudo que está se desenvolvendo, incluindo a própria invisibilidade e mudez do outro, é o não- 
sentido inicial que justifica, em um primeiro momento, a pronta reação dos agentes em acionar dispositivos eletrônicos com o intuito de resolver o problema gerado pela falta de comunicação. A representação dessas providências já evidencia o contraste entre duas posturas - enquanto o outro é representado como incomunicável, o eu se sobressai como aquele que privilegia a palavra, tomando posse da mesma em primeiro lugar. O trabalho de construção do diálogo fílmico, em que personagens com as mais diversas características interagem a partir do ponto de vista do narrador, só pode ocorrer levando-se em conta as imagens que este tem, por exemplo, daquilo que, no mundo tangível de sua realidade, está por trás do perfil do personagem criado.

Para melhor compreender, sob a perspectiva discursiva, a representação sobre a postura contrária à comunicação atribuída ao outro nesse diálogo, servimo-nos do conceito de formações imaginárias para desconstruir a aparente despretensão da fala "no communication of any kind”. Na interação com o outro, ainda que não percebamos, dá-se sempre o processo da antecipação no qual imagens são produzidas a partir de perguntas do tipo "quem sou eu para lhe falar assim”, ou “quem é ele para me falar assim?”. Esse é um conceito de Michel Pêcheux explorado com freqüência por analistas de discurso e que é definido por Orlandi como “um jogo imaginário que preside a troca de palavras” (2002:40). Aplicando tal conceito como dispositivo para a análise do corpus, podemos afirmar que nos diálogos construídos para um filme, assim como ocorre em um romance, as palavras, falas e pontos de vista atribuídos aos personagens também são submetidas a esse processo de antecipação a partir de perguntas em parte semelhantes às acima como "quem é ele (que imagem eu faço dele) para que eu possa falar, mostrar e sugerir algo a seu respeito?”, ou, em outros casos, “quem é ele (que imagem eu faço dele) ou que imagem eu faço da imagem que ele faz de mim para que eu determine aquilo que ele me diria?”. Fica claro que, no corpus, o "ele" dentro da pergunta formulada acima se refere a figuras fora do espaço da tela, no caso, o inimigo apontado pelo governo norte-americano no período de produção do filme, personificado pelo terrorista de origem árabe e islamita.

A exclusão do outro da possibilidade de uma interação mais concreta e visível na cena, considerando o padrão de interação verbal preconizado pelo filme, ocorre em função da diferença a ele atribuída, uma vez que é representado como aquele que se indispõe a se comunicar, do mesmo modo que, fora da ficção cinematográfica, o oriental árabe costuma ter sua inscrição marcada pelo mistério, como a exibição telejornalística de gravações de ameaças ou de cenas de violência que, juntas, acabam se tornando o único modo de "falar" do outro em outras palavras, sua única linguagem. No trecho analisado, o espaço que estaria reservado 
para o outro “falar” é representado como completamente ignorado por meio da construção de uma situação na qual sua indisposição em se comunicar (esse vácuo sonoro) é compensada com os dizeres do eu, que se beneficia desse tipo de representação do outro como um corpo silente, próprio, como sabemos, da retórica colonialista. Observemos que um dos modos pelos quais se representa o outro como inábil para a comunicação (o que sugere a pouca funcionabilidade da língua desse sujeito, visto que a tem mas não a utiliza) se dá com o uso de uma palavra que, embora previsível em um contexto de ataque terrorista, faz parte também das formações discursivas nas quais o ideal de democracia se insere: to negotiate. Esse é o termo com o qual o eu deve se identificar e que deve ser rejeitado pelo outro, como se percebe na conclusão a que Elise Kraft chega ao observar o quadro que se desenvolve diante de todos: “They're not here to negotiate”. A culpabilidade do outro é, portanto, representada como um pressuposto, pois a ausência de comunicação e sua indisposição de negociar indicam a culpa de um réu que se torna confesso. O verbo "negotiate” traz implícita a idéia de conversar, argumentar, utilizar essa característica humana, logo, se o outro, seja porque não consegue se expressar em inglês, seja porque não deseja se expressar independentemente do idioma, não manifesta intenção de conversar, cabe às autoridades em questão falarem em seu lugar e fazerem aquilo que julgam apropriado, ocupando portanto o espaço que não pode permanecer vazio. A mudez atribuída ao outro, bem como a resistência à negociação e o rebaixamento de sua capacidade de entendimento produzem uma representação da língua do eu como o veículo por meio do qual a harmonia será defendida e almejada. É isso que ocorre quando, para espanto de todos os presentes, Hubbard ousa arriscar uma aproximação do veículo seqüestrado, com um telefone e um intérprete a seu lado, para tentar a negociação (FIGURA 12). A libertação das crianças se torna um primeiro modo de mostrar que, em parte, a negociação foi bem sucedida e confere ao outro (temporariamente, vale dizer) uma certa flexibilidade (qualidade celebratória); todavia, a surpreendente explosão no momento em que todos esperavam um novo êxito, se por um lado choca pelas imagens, por outro, desfaz qualquer identificação com o outro que o espectador pudesse ter experimentado por ocasião da atitude compreensiva e humana de libertar, ainda que fossem, as crianças. É verdade que o filme depende em grande parte do movimento e do elemento da surpresa constantemente, mas no caso, como vimos demonstrando, parece tratar-se da necessidade de construir a imagem do outro como aquilo que o eu não é, assim definindo as identidades do modo como convém em um determinado momento histórico. Importa destacar o recurso utilizado após a explosão do ônibus com a câmera lenta que, sob uma trilha sonora que tenta remeter ao Oriente, mostra detalhes demorados do sofrimento da principal vítima, Anthony Hubbard, enfatizando o 
sangue que começa a escorrer por sua narina (FIGURA 13). Demora-se na exibição do sofrimento e decepção deste diante da insensibilidade e indisposição do outro em envolver-se em uma situação de conciliação que poderia evitar tamanha catástrofe. A própria exibição do sangue na cena cumpre aqui o papel de um importante elemento narrativo que reforça a noção da necessidade de se lutar por uma causa até as últimas conseqüências. Na cena seguinte, o agente Hubbard é mostrado usando a mesma camisa com as marcas do sangue ainda presentes no nariz e colarinho.
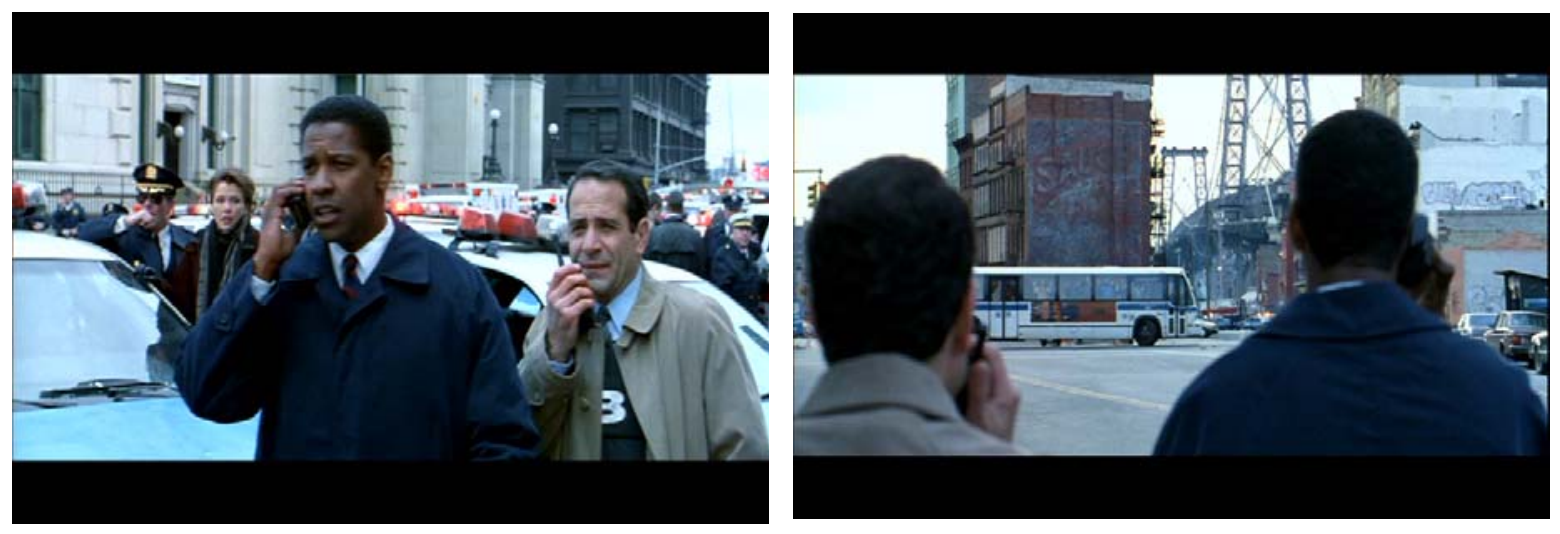

Figura 12: Personagens Anthony Hubbard e Frank Haddad
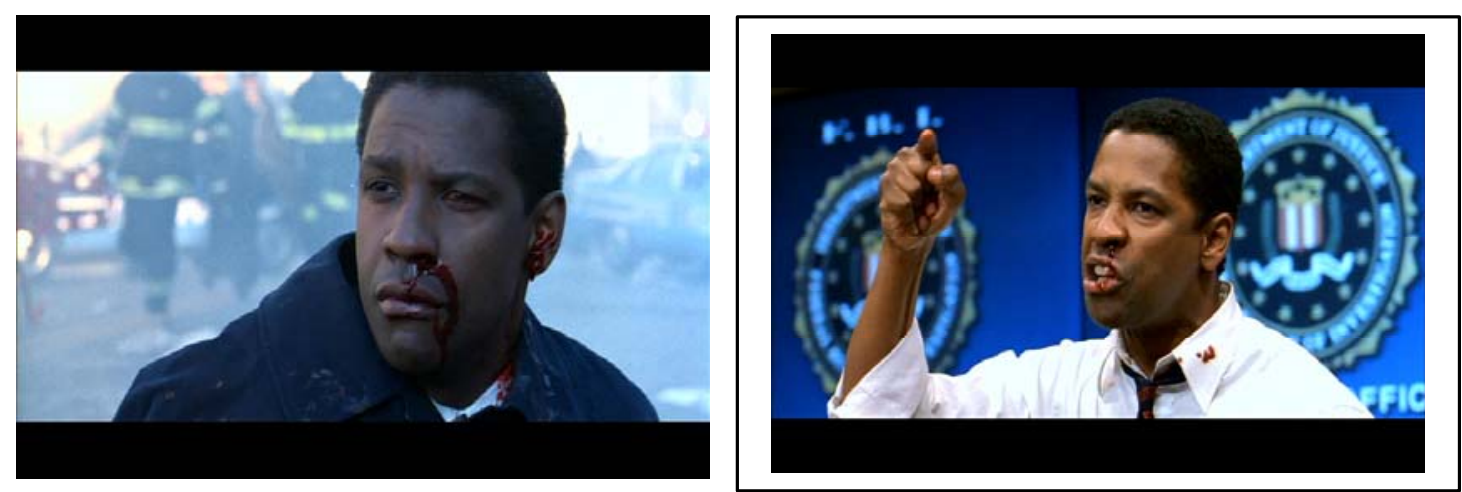

Figura 13: À esquerda, logo após a explosão. À direita, comunicando seu plano de ação.

Na relação de forças presentes em 2, o lugar a partir do qual o eu fala é, com base em Orlandi (2002), constitutivo do que ele diz (p. 39), e esse é o lugar da conciliação, da promoção da paz, da conscientização - ou seja, do "bem”, como se observa na recusa de Hubbard a acatar a sugestão de Elise de atirar e matar os seqüestradores o quanto antes. Sabendo que há crianças no veículo, o agente decide usar esse fato para tentar sensibilizar o inimigo a desistir de seu propósito, mas o que esse gesto deixa à mostra, segundo nossa leitura do ponto de vista discursivo, é menos um discurso sobre a compaixão do que uma 
representação de si como defensor incondicional da negociação, qualidade que está pressuposta no ideal de democracia do sujeito que tenta conduzir essa leitura. É possível ilustrar imageticamente essa retórica com inúmeros exemplos da história política norteamericana nos quais o ideal de valorização da negociação e diplomacia se materializa. Uma das imagens ilustrativas que se tornaram mais populares está associada ao governo Clinton e registra a preocupação (e oportunidade) que teve sua administração de promover o fim do conflito entre palestinos e judeus. Posicionado no meio dos dois líderes representativos de cada um desses povos, o então presidente é representado celebrando um momento que se julgava dos mais importantes na história mundial - o Acordo de Oslo, em 1993 (FIGURA 14).

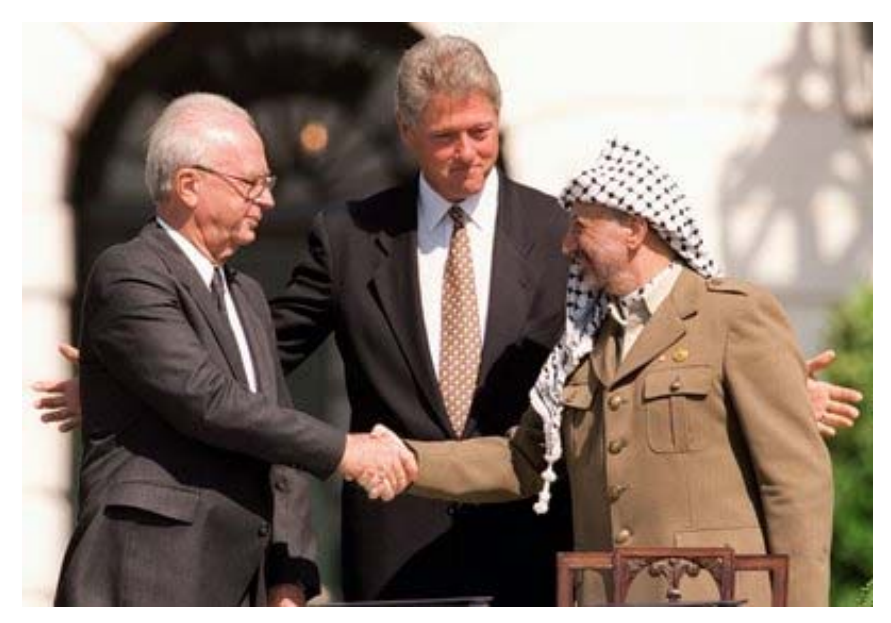

Figura 14: Da esquerda para a direita: Yitzhak Rabin, Bill Clinton e Yasser Arafat.

O lugar do "bem" a partir do qual fala o personagem Hubbard nesse trecho pode ser também observado no modo cordial como se dirige àquele que é representado como seu inimigo (Hello sir. My name is Anthony. / You need anything in there? Any medical supplies?). É verdade, no entanto, que essa cordialidade faz parte de uma estratégia de negociação na qual se tenta obter a simpatia do interlocutor; de todo modo, a apresentação de si nesse momento também reforça o contraste que se cria com a representação de duas posturas, pois o fato mesmo de o agente dizer o seu nome e "se mostrar" contrasta com o completo anonimato do outro. Não obstante auxiliado por um intérprete que procura reproduzir em árabe as palavras ditas por Hubbard em inglês, o entendimento por parte do outro é rebaixado, a julgar pelo comentário de Frank “I don’t even know if they understand”. Observamos também que, nessa representação sobre o outro, não se afirma que sua língua seja o árabe (é apenas possível que seja). Esse é mais um exemplo de que o espaço reservado para o outro falar precisa ser representado no filme como ignorado para que a intervenção do eu prevaleça como a única a privilegiar o diálogo, como se nota no comentário "I know you 
may not want to talk to me, but are you willing to listen to me?”, no qual também notamos o emprego de uma marca de modalização ${ }^{36}$ (may not) ao sugerir que o outro estaria, desde sempre, indisposto a conversar com ele. Nos diversos trechos analisados ao longo do trabalho, a ação dos agentes parte sempre dessa qualidade “inata” do outro de indisposição à comunicação, como um corpo essencialmente silente. Eis porque argumentamos que a língua do eu, conquanto não nomeada do modo como ocorre com o árabe, é celebrada através de suas escolhas lexicais, sua sonoridade e sua própria condição de ser veículo de comentários elogiosos e engrandecedores, como ocorre no momento em que Hubbard, ao ver as crianças sendo libertadas, reage dizendo que "the best way to get what you want in this situation is to show yourself to be reasonable”, acionando também uma memória discursiva dentro da qual o oriental é percebido como carente de razão e lógica. A incompetência atribuída ao outro faz com que o eu sempre reclame para si a racionalidade, a objetividade e transparência, como teremos oportunidade de demonstrar mais adiante. Essa transparência atribuída a si pode ser observada até mesmo na materialidade imagética do ônibus seqüestrado quando notamos as expressões de desespero dos passageiros através das janelas do veículo (FIGURA 15), visto que são representados como tendo rostos, sentimentos, identidades. Essa barreira montada com os corpos dos passageiros em pé também favorece a ocultação da possível imagem do(s) seqüestrador(es) em alguma parte no interior do veículo. O diálogo monológico dessa seqüência discursiva acaba denunciando em uma de suas falas, quase que em um ato falho, o investimento ideológico de silenciamento da alteridade quando Hubbard declara que tomará o "silêncio" do outro como uma resposta de que aceita a oferta que ele, Hubbard, propõe na negociação. Embora entendamos que o silêncio, do modo como Orlandi (1992) o definiu, não está relacionado a "ausência de palavras” ou tentativa de calar o interlocutor, mas sim, ao impedimento de que este sustente “outro discurso” (p. 105), no trecho analisado, conquanto a ausência de palavras seja imposta ao outro no seu sentido "literal”, pode-se dizer que isso ocorre também como um meio de impedir que esse personagem fale mais que o necessário no curto espaço de duração da cena. Sim, porque há ocasiões em que o outro também fala no filme, ainda que nunca no mesmo nível de compreensão do eu, como veremos a seguir.

\footnotetext{
${ }^{36}$ Essas marcas de modalização serão analisadas com mais especificidade na terceira e última parte da análise.
} 

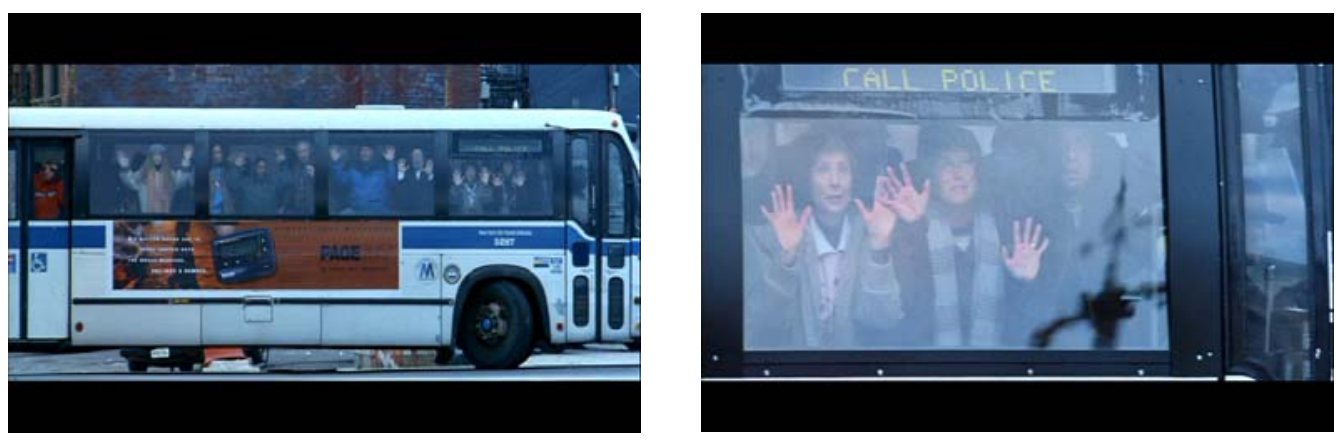

Figura 15: Imagem dos passageiros que estão a bordo do Bus 87.

\subsection{2 - Respostas que não respondem}

SD3

Contexto: Após o episódio da explosão do “bus 87”, o FBI intensifica as investigações e interroga Khalil, por acreditarem que ele pode estar ocultando o que sabe acerca dos ataques. Interrogado por Anthony Hubbard, Khalil é pressionado a esclarecer a origem de um valor em dinheiro que ele carregava em uma mala, motivo pelo qual já havia sido chamado para prestar depoimento anteriormente. Hubbard conta novamente com o auxílio lingüístico de Frank Haddad na condução do interrogatório.

Hubbard: Tell me about the money.

Khalil: (fala em árabe)

Frank: He says he loves America. He only wanted to get away from the security services.

Hubbard: Sure, sure. Tell me about the money.

Khalil: (fala em árabe)

Frank: He says sorry. He didn't know he was doing anything bad.

Hubbard (grita irritado): Tell me about the money!

Khalil: (chora e fala em árabe)

Frank: His cousin introduced him to a man who promised him 200 dollars for his dowry if he took the suitcase to an address in Brooklyn. He’s a mule.

Com a análise dessa seqüência discursiva, gostaríamos de chamar a atenção para o aspecto da objetividade no modo de falar que é atribuída ao eu por meio da própria construção do diálogo. Pode-se argumentar que, dentro de uma política lingüística não declarada que definiria como racional e objetiva uma certa maneira de se expressar, está implícita a idéia de uma ordem da língua que considera outros modos de se expressar impróprios, errados, “bárbaros”. Barbarismo era o termo que os Antigos usavam para designar, segundo Gadet e 
Pêcheux, o “inferno ininteligível” de tudo que caía fora da linguagem (2004:30), e é esse aspecto da representação sobre o outro que se pretende problematizar na análise desse trecho.

Como se nota, Anthony Hubbard repete a mesma ordem (Tell me about the money) três vezes, sendo que após a segunda tentativa impacienta-se e vocifera com o interrogado, revelando, com esse rompante, que a serenidade que caracteriza sua personalidade se rende e se desestrutura diante da falta de clareza do outro. Trata-se de um conflito que não pode ser associado apenas à problemática interna do filme (os ataques terroristas em si), mas ao confronto de duas maneiras de se expressar e, mais indiretamente, de duas línguas. Embora tenha aparentemente entendido a ordem desde o início (até porque há um intérprete presente), o suspeito Khalil não "responde” de imediato, preferindo demorar-se enfatizando seu amor pela América e desculpando-se por não saber que estava “fazendo algo ruim”. Aqui, portanto, entendemos que a língua do eu é representada como objetiva em sua forma imperativa (Tell me about the money), ao passo que a resposta de Khalil é insuficiente mesmo no seu excesso, ininteligível e digressiva, além de incômoda para o interlocutor. Como se percebe, o espaço no filme reservado à fala do outro é sempre marcado por algum tipo de ininteligibilidade, pois tanto sua mudez em 2 quanto as palavras supérfluas em 3 são representadas como ausência ou algo improdutivo do ponto de vista da coerência e simetria valorizadas no filme.

Não poderíamos deixar de levar em consideração nessa análise também o aspecto da imagem com o enquadramento dos personagens que igualmente produz efeitos de sentido. Interessa notar que, como pudemos demonstrar na análise da seqüência de abertura, o personagem americano está sempre em uma posição espacial superior em relação ao estrangeiro. No caso em questão, além da visível inferioridade espacial de Khalil, sua expressão de insegurança e medo no olhar indicam, durante toda a cena, que o ponto de vista nunca lhe pertence, estando sempre associado a Hubbard, ou até mesmo ao intérprete (FIGURA 16), o qual também é mostrado em uma dimensão superior à de Khalil. Não estamos afirmando que esses recursos imagéticos estão presentes de modo particular nesse filme, até porque esse é um recurso cinematográfico empregado sempre que se deseja explicitar quem detém o ponto de vista, mas queremos apontar que tais enquadramentos também confirmam a hipótese que sustentamos de que, apesar de não nomeada, a língua do eu, com vários aspectos funcionando a seu favor, subjuga a do outro, impedindo ou dificultando sua utilização como um modo de inscrição verbal coerente na trama. Com uma das mãos presa à parede da sala de interrogatório, e sob constante (porém falsa) ameaça de ser torturado com a chama do cigarro, Khalil é pressionado a produzir uma única resposta, vendo extintas, de certo modo, as chances de se inscrever na cena com algum tipo de subjetividade 
além do próprio nome. É verdade que a natureza de Hubbard impediria o uso do recurso da tortura, como se confirma no final da cena, no instante em que surpreende o interrogado presenteando-o (já que concluem que ele não é tão ‘culpado’ como imaginavam) com o cigarro já aceso, mas mesmo esse gesto representado como cordial da parte do agente liberal está em conformidade com a imagem ahistórica do outro reduzida a costumes, pois Hubbard observa em outros momentos do filme (também a partir de comentários de Frank Haddad) que o hábito de fumar muito é comum entre "eles”.
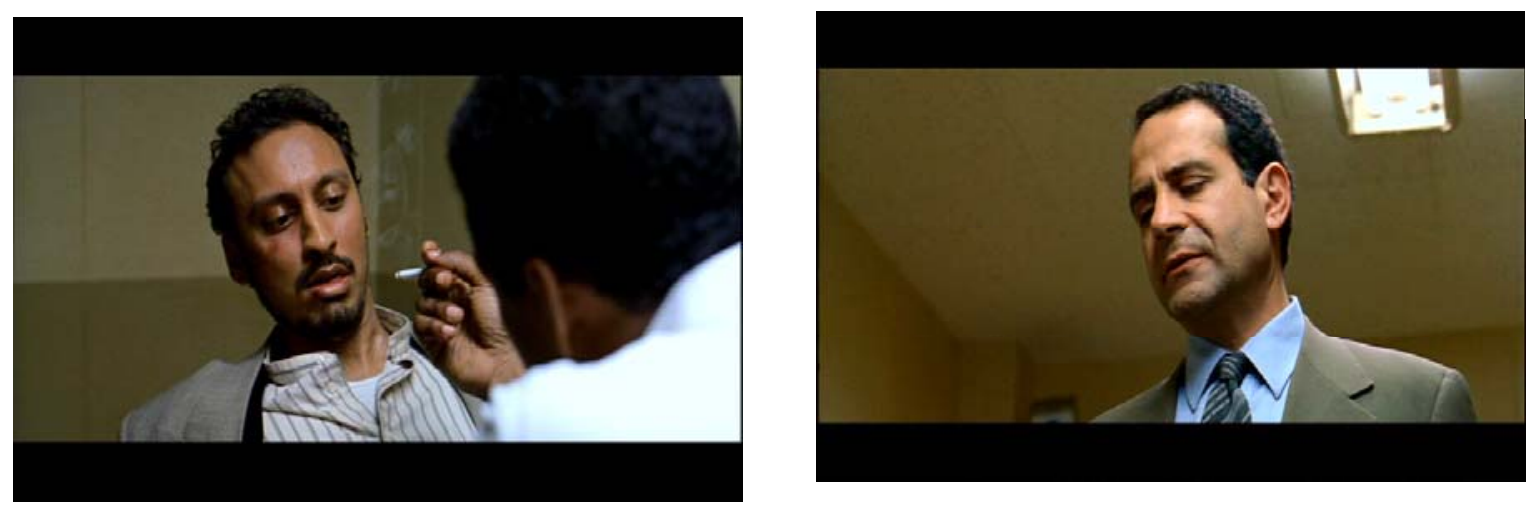

Figura 16: À esquerda: Khalil é interrogado por Anthony Hubbard. À direita, Frank Haddad observa.

Considerando que a representação sobre o modo de dizer do outro como digressivo e insuficiente faz sobressair, por oposição, o modo de dizer do eu como claro, racional e objetivo, pode-se argumentar que esse diálogo faz funcionar também a noção de correto e incorreto na língua, e aqui poderíamos considerar aquilo que Guimarães (2002) chama de "hierarquia de identidades”, provocada por uma tal divisão da língua. Segundo o autor, "esta divisão distribui desigualmente os falantes segundo os valores próprios desta hierarquia” (p. 21), como temos mostrado tanto na materialidade lingüística quanto na materialidade imagética dessa seqüência discursiva. Evidentemente, o caráter de correção/incorreção que estamos invocando concebe essa divisão no interior de uma única língua (o correto e o incorreto na língua inglesa, por exemplo), mas se nos afastarmos um pouco da idéia de que no trecho em questão há dois idiomas distintos em jogo, e considerarmos ambos como uma única língua que os personagens utilizam dentro da narrativa da história, então podemos entender melhor por que o conceito de correto e incorreto pode ser aplicável nesse caso. Vale dizer, todavia, que o caráter de correção atribuído ao modo de dizer do interrogante no filme não está associado ao “dogmatismo da norma”, isto é, à gramática entendida como arte do falar (e escrever) corretamente e, sim, "aos usos que permitam a expressão ou comunicação dos pensamentos adequadamente”, como conclui Mariani (2004:170-1) a partir da citação de 
Pêcheux acerca da língua inglesa no contexto americano e de algumas definições de “gramática” por alguns autores ingleses. Língua, nesse contexto, é entendida como “órgãoferramenta” de que o sujeito se serve para se exprimir, e o que de fato conta, nesse caso, não é a sistematização da mesma, mas o treinamento oral, a elocução, a dicção e a leitura.

O inglês é considerado por certos autores como a língua da "liberdade”, aberta a evoluções e sem regras acadêmicas rígidas que controlam sua evolução do modo como ocorre com outras línguas, mas nenhuma língua escapa ao político. O controle que caracteriza essa política lingüística no filme parece ter como objetivo punir a falta de racionalidade nos modos de se expressar e, no caso analisado, importa considerar também que imagem do outro é construída para que se possa falar do mesmo. Essa imagem, como já se sabe, está diretamente vinculada aos sentidos produzidos pela tradição orientalista, dentro da qual as noções de aberração e subdesenvolvimento atribuídas ao Oriente são aspectos bastante representativos. A imagem do Ocidente como racional, superior, humanitário e desenvolvido se constrói a partir da imagem do outro como incapaz de desenvolver suas potencialidades intelectuais. Com nossa leitura de Said (2007), podemos afirmar que essas manifestações culturais contemporâneas fazem parte também daquilo que o autor chama de "versões mais ou menos diluídas do antigo Orientalismo” (p. 401), sobretudo quando comparamos representações como as que o filme constrói com outras realizadas em textos criados já no alvorecer do século XX e que representavam a "mente oriental” como imprecisa e carente de simetria (cf. Capítulo III).

A propósito da nossa constatação de uma representação sobre a língua do outro como confusa no trecho acima, caberia citar o ensaio de E. Shouby ${ }^{37}$ "A influência da língua árabe sobre a psicologia dos árabes”, que Said define como um dos exemplos de insinuações e hipóteses que acabaram sendo transformadas em “verdades indiscutíveis” do orientalismo (p. 426). Embora o autor demonstre sua admiração de que algo simplista nesse sentido possa ser afirmado em relação a qualquer outra língua (entendendo que uma língua não pode ser transformada no equivalente da mente), nos faz refletir sobre as influências que um ensaio como esse pode exercer no modo de perceber o outro. Dos três subtítulos do ensaio que Said menciona para sustentar sua posição, um interessa de modo particular à presente análise, qual seja, “Vago caráter geral de pensamento”, pois para E. Shouby a língua árabe seria um sinal de mudez combinado com uma inútil articulação excessiva, "pobreza combinada com excesso” (apud SAID, 2007:427). No trecho analisado, não se afirma que tal “pobreza” possa

\footnotetext{
${ }^{37}$ Publicado em "Middle East Journal 5” (1951). Parte da coletânea "Readings in Arab Middle Eastern societies and cultures”, ed. Abdulla Lutfiyye e Charles W. Churchill (Haia: Mouton \& Co., 1970), pp. 688-703.
} 
existir nas palavras do outro, mas é possível argumentar que essa noção entre como um pressuposto quando da criação da fala do personagem.

Concluindo as reflexões acerca desse trecho, entendemos que, se o idioma árabe é representado com qualidades depreciativas no filme, o inglês, por sua vez, ainda que jamais nomeado, acaba se manifestando com uma identidade próxima daquela que Jean-Marie Le Breton lhe atribui em suas reflexões sobre a geopolítica do inglês, qual seja, a da língua "do progresso, [...] da inovação, [...] dos homens que são seguros de si e que podem ser tomados como modelo" (2005:21).

\subsection{3 - “Doory ${ }^{38}$, dowry... or duty?”: vários sentidos em uma palavra}

Gostaríamos de esclarecer que, na tentativa de estabelecer um vínculo maior entre os aspectos que queremos apontar nas representações sobre o outro, organizando-os, inclusive, em diferentes partes do capítulo, não estamos obedecendo à cronologia com que os eventos ocorrem ao longo do filme. Em razão desse critério, o fato de que a cena em 4 seja anterior à cena mostrada em 3 não interfere nos resultados da análise, como poderemos observar.

\section{SD4}

Contexto: Após o primeiro ataque terrorista na cidade (na verdade, apenas um sinal de alerta com a explosão de um artefato que espalha tinta azul em pó nos corpos dos passageiros de um ônibus), o FBI identifica um primeiro suspeito, Khalil Saleh. A seqüência inicia com um dos agentes mostrando ao líder Anthony Hubbard uma mala com dinheiro que estava em poder do suspeito. Concomitantemente ao desenvolvimento dessa cena envolvendo vários agentes em um ambiente, ocorre o interrogatório de Khalil em um espaço mais reservado. Do lado de fora desta sala, Hubbard e sua equipe, entre os quais Frank Haddad, conseguem ouvir o interrogatório e observar tudo que se passa ali através de uma divisória de vidro.

Agente: Underneath the false bottom, we found this. All in small bills, so we figured smurf, right? And considering yesterday's terrorist alert, and where he's [Khalil] been recently, we'd better call Frank.

Frank: Who's trying to score points with his boss big-time.

Hubbard: Has he broken any laws?

\footnotetext{
${ }^{38}$ A rigor, essa palavra não existe na língua inglesa. Trata-se da transcrição usada para representar a pronúncia de Khalil para a palavra inglesa “dowry” (dote).
} 
Agente: No, sir. He is twenty dollars under the ten thousand limit.

Frank (colocando uma nota de 20 dólares na mala): Not anymore.

Interrogante: So, Khalil, you're saying this is an inheritance? Somebody died, and you're bringing them the money...

Khalil: No, no, no... Doory. Doory.

Frank: He means dowry.

Interrogante: You're expecting me to believe you brought in ten thousand dollars for a wedding?

Hubbard (notando cicatrizes no pescoço de Khalil): Check out his neck.

Frank (indicando com gestos que a prática de marcar a pele com chama de cigarro é comum entre esse povo): The tobacco ... territories.

Hubbard: Put him in play.

Khalil: Doory. Doory.

Interrogante: Ten thousand dollars is a lot of money. Where does a guy like you get that money?

A seqüência de eventos atribuídos aos agentes que encontraram uma mala suspeita pode estar revelando, entre outras qualidades positivas, como o próprio fato de terem identificado um suspeito em tão pouco tempo, sua capacidade de inferência representada através de expressões de dedução como “so we figured...” e “and considering...”. A celebração dessas qualidades é representada no diálogo por meio do comentário espirituoso de Frank que, com essas provas, ele estaria tentando "ganhar pontos com seu chefe". O ritmo desse breve diálogo marcado por respostas rápidas e “criativas”, como a reação de Frank à informação de que faltam vinte dólares para que o suspeito possa ser acusado de violação de alguma lei, confere certa mobilidade ao diálogo. Todavia, o dinamismo dessa conversa entre os agentes é contrastado em seguida pela morosidade e imprecisão comunicativa no momento em que o ponto de escuta se transfere para o interrogatório que acontece na sala ao lado. Importa ressaltar o trabalho de enquadramento da câmera que se organiza no sentido de mostrar ambas as situações, por vezes concomitantemente, sem necessitar de cortes, já que o recurso da parede de vidro divide os ambientes ao mesmo tempo em que os integra. O único obstáculo dessa tentativa de completude imagética é mesmo o ponto de escuta, já que o 
volume do áudio dos dois diálogos concomitantes varia de acordo com o foco que o filme determina para a seqüência. A parte de Khalil no diálogo é representada como incômoda e geradora de dificuldade para o interrogante devido ao modo como ele tenta se expressar em inglês. Considerando que nenhum detalhe em um filme é gratuito, o fato de que a parte do interrogatório considerada oportuna para a cena esteja centrada no problema de má pronúncia deve ser percebido como um aspecto relevante da representação sobre o outro na narrativa, ainda que possa parecer incidental. A decisão de mostrar apenas esse trecho do interrogatório caracteriza, evidentemente, um caso claro e simples de elipse, que se justifica pela economia do tempo fílmico, mas essa mesma escolha é reveladora, a nosso ver, de um investimento do filme no sentido de colocar em cena duas formas de dizer e dois modos de expressão visivelmente contrastantes. Neste ponto convém que nos detenhamos no conceito de elipse dentro dos estudos cinematográficos, uma vez que se costuma afirmar, segundo Martin (1990) que “o cinema é a arte da elipse” (p. 75). O autor prossegue observando que:

A elipse faz parte necessariamente tanto do fato artístico cinematográfico como das outras artes, pois, desde que haja atividade artística, há escolha. O cineasta, como o dramaturgo e o romancista, escolhe elementos significativos e os ordena numa obra. [...] Tal capacidade de evocação em meias-palavras é um dos segredos do espantoso poder de sugestão do cinema. [...] Mais comumente a elipse tem por objetivo dissimular um instante decisivo da ação para suscitar no espectador um sentimento de espera ansiosa, o chamado suspense, que os diretores americanos tanto prezam (pp. 75-78).

São diversos os tipos de elipse das quais o cinema lança mão com freqüência, e o autor consegue agrupá-los em três categorias: as objetivas (no caso da dissimulação de algo para o espectador), as subjetivas (no caso de o ponto de escuta de um personagem ser oferecido ao espectador para justificar a elipse do som) e as simbólicas (no caso de a dissimulação de um elemento revestir-se de uma significação mais profunda); porém, não se pode negar que a elipse pressupõe, inevitavelmente, uma interpelação do indivíduo em sujeito pela ideologia. A noção dessas escolhas se harmoniza também com um dos princípios da Análise do Discurso de que, quando usamos uma palavra, estamos necessariamente deixando de usar outras tantas possíveis, como se aquela fosse a única opção. No caso analisado, pode-se expandir esse conceito às imagens, já que a escolha de um ângulo ou um enquadramento implica descartar outros ângulos e enquadramentos possíveis. Pois bem, fica claro que, a partir da primeira fala 
do interrogante (So, Khalil, you're saying this is an inheritance? ...) e da resposta do interrogado (No, no, no... Doory...), o problema de compreensão já vinha ocorrendo ao longo da conversa e, segundo nossa leitura, a metalinguagem empregada pelo primeiro, que tenta esclarecer com outras palavras o significado de “inheritance”, como também a interpretação de Frank para o estranho som “doory” produzido pelo interrogado, acabam identificando os agentes do serviço de inteligência com a habilidade de interpretar mesmo aquilo que, por parte do outro, se mostra enigmático.

A propósito da observação do contraste que se manifesta com a representação de duas maneiras de se expressar diferentes nessa seqüência discursiva, vale sempre destacar o papel imprescindível do outro nas narrativas que trabalham os processos identitários, pois é necessário ilustrar a “incorreção” para que a “correção” possa sobressair. Essa leitura que realizamos em nossa época nos permite propor que o discurso aqui analisado também se articula com o discurso dos colonizadores sobre os modos de dizer das populações nativas. Embora esteja tratando especificamente do processo de colonização lingüística no contexto brasileiro, julgamos pertinente trazer para nossa reflexão o que Mariani (2004) coloca a propósito de sua análise das palavras de Pero Vaz de Caminha na Carta com relação à questão das línguas indígena e portuguesa no processo de colonização e catequese. A autora considera que:

É interessante observar, no gesto de interpretação de Pero Vaz de Caminha, como é designado esse contato lingüístico inicial marcado pelo desentendimento. Há um bordão repetido incessantemente - "nem fala nem entendimento" - marcando a incompreensão lingüística e o fato de que os índios (apenas) "falam”, enquanto os portugueses, além de “falar”, “perguntam”, “concordam”, “tomam resoluções” (2004:47) (grifos nossos).

É verdade que, na Carta, a língua do outro não é a do colonizador (o português), ao passo que, em nosso corpus, a língua usada pelo outro nesse trecho específico do filme também é o inglês, porém, a língua do “colonizador” falada por Khalil nessa oportunidade recebe um tratamento tal que a transforma em uma "língua estrangeira”, resultando em desentendimento ('doory'? duty? dowry?). Observemos também que, do mesmo modo como na narrativa referente ao episódio da Carta, os portugueses serão representados como "bem sucedidos" em virtude de seus recursos extra-lingüísticos que resultaram, ainda segundo Mariani, em "uma 'resposta' especular por parte dos índios" (2004:46), nas situações de 
desentendimento que indicamos neste trabalho, o eu também sempre procura representar seu êxito em interpretar o que se mostra confuso e desorganizado, garantindo a clareza dos sentidos, como no instante em que Frank intervém e esclarece o problema de pronúncia.

Observando essa questão de pronúncia sob uma outra perspectiva, podemos agora expandir a análise chamando a atenção para o fato de que uma situação aparentemente despretensiosa de representação do estrangeiro com sotaque marcado pode cumprir um papel mais estrutural de mostrar a presença da alteridade na linha do discurso. É verdade que muitos filmes, propagandas e programas de televisão (sobretudo humorísticos) invariavelmente lançam mão de estereótipos quando lidam com personagens estrangeiros (por exemplo, alemães dizendo ‘aquela carro’ ou ingleses dizendo 'eu querer isso’), porém, no caso sob análise, dadas as condições de produção, não se pode afirmar que se trata de um fenômeno semelhante, visto que, como temos tentado mostrar, essa presença precisa aparecer como a antítese do eu (ou do Ocidente), inclusive sob o aspecto lingüístico. Tomando o exemplo do som “doory” produzido por Khalil no interrogatório, notamos que estamos diante do tipo de heterogeneidade mostrada que Authier-Revuz (2004) classifica como "das outras palavras, sob as palavras, nas palavras” (p. 18), em que poderíamos incluir casos como de homonímia, paronímia, polissemia, trocadilhos, entre tantos outros. Sem desejar explorar verdadeiramente esse campo da língua, a autora apenas aponta a relevância de se atentar para tais modalidades explícitas "pelas quais a presença de outro significante pode ser marcada em uma seqüência, para um interlocutor que não pode, portanto, ignorá-la, inclusive sob a forma de uma instrução para descobrir esse outro” (p. 18). Esta última observação contribui particularmente para a compreensão do caráter não incidente também dessa marca no trecho analisado, pois sinaliza para o trabalho da ideologia que, de inúmeras maneiras que não podem aparecer, convida o espectador do filme a descobrir o que há de diferente, o que causa incompreensão e o que pode ameaçar.

Ainda a propósito desse problema de pronúncia, notamos que sua inclusão na cena, com o esclarecimento de Frank, pode também estar relacionada a um aspecto das condições de produção do filme. Considerando seu ano de produção (1998) e o episódio que ele resgata e transforma em ficção (o atentado em Dhahran em 1996), é possível especular que o jogo paronímico de palavras seja a maneira escolhida, entre outras possíveis, de fazer referência ao decreto religioso (fatwa) assinado por Osama Bin Laden e publicado em um jornal inglês à 
época. Como o texto parece enfatizar a palavra “duty”39 (obrigação legal ou moral), a pronúncia estranha poderia estar sugerindo a Anthony Hubbard que Khalil estivesse fazendo referência a esse imperativo do decreto, o qual chega a ser mencionado na abertura do filme em um dos relatos dos repórteres (cf. descrição da Cena 2 no Item 4.2 deste capítulo), ainda que o áudio se torne pouco perceptível no momento em que a palavra fatwa é proferida - sua menção coincide com o momento em que se emprega o recurso de fade out, com o desaparecimento gradual do som. Nosso argumento se baseia também em um dos princípios da Análise do Discurso, segundo o qual compreender é "saber como um objeto simbólico (enunciado, texto, pintura, música etc) produz sentido” (ORLANDI, 2002:26), e isso só é possível quando se busca "escutar” sentidos outros que possam estar presentes no texto.

Outro aspecto que julgamos relevante no trecho acima é que, mesmo após ter resolvido aparentemente o problema de pronúncia de Khalil, o interrogante demonstra que não acredita que o dinheiro acondicionado no fundo da mala seria utilizado para fins de “dowry” (You're expecting me to believe [...] Where does a guy like you get that money?), reação que está em conformidade com o tipo de representação construído sobre o outro e que se apresenta em diferentes situações criadas para os personagens. Nesse caso específico, o outro estaria sendo representado como aquele que não transmite credibilidade quando fala. Essa assimetria no que concerne ao caráter de verdade atribuído ao eu e de incredulidade atribuído ao outro pode ser observada aqui também a partir da materialidade imagética da cena que funde os dois ambientes (a sala do interrogatório e o espaço maior em que os agentes observam do lado de fora), mostrando o reflexo de Hubbard e Frank na parede de vidro que separa os dois ambientes (FIGURA 17). Como se nota na figura, Khalil é a única pessoa sentada, com o interrogante em pé a seu lado e a imagem dos agentes também em pé refletida no vidro. Devemos notar outro aspecto de assimetria também em relação à escuta dos diálogos, uma vez que Khalil não tem conhecimento que seu interrogatório está sendo acompanhado por outros ouvidos e olhares além dos de seu interrogante. A simetria imagética dos agentes e do interrogante encontra também seu correspondente no próprio conteúdo dos diálogos, uma vez que todos os que são mostrados em pé na cena partilham da mesma imagem do outro para pensá-lo ou interagir com o mesmo. Na imagem, que deve, de algum modo, "traduzir" que Khalil é sempre o objeto do olhar e escuta de outros, fica clara essa hierarquia de valores quando observamos que, em nenhum plano, o seu olhar é tomado como

\footnotetext{
39 “ $[. .$.$] the jihad is an individual duty if the enemy destroys the Muslim countries. [...] The ruling to kill the$ Americans and their allies - civilians and military - is an individual duty for every Muslim who can do it in any country in which it is possible to do it."
} 
detentor de alguma autoridade - dito de outro modo, o interrogado é sempre visto de cima e escutado de todos os lados. Também aqui não estamos defendendo que esse ponto de vista mostrado no nível da imagem (o rebaixamento 'espacial' do outro) seja um fenômeno isolado e exclusivo do filme analisado, mas queremos apontar que as convenções cinematográficas (sim, porque cineastas de outras nacionalidades também podem se servir dessa linguagem) sempre revelam mais daquilo que seus agentes acreditam mostrar. Harris Watts (1999), por exemplo, esclarece que um filme "sem um ponto de vista" (se isso fosse possível, acrescentaríamos) estimula críticas do tipo “e daí” (p. 17), e acrescenta que sua recomendação (a interessados em produzir filmes) a buscar sempre um ponto de vista não é um estímulo a apresentar a trama de maneira tendenciosa, mas a "pensar numa forma de contar a história que a faça ter algum significado para o espectador” (ibidem); todavia, o autor peca ao afirmar que esses cuidados não sugerem um caráter tendencioso do filme. Ora, se o próprio Watts justifica, em outras partes de seu "manual” de fazer cinema, o uso de recursos como os do close-up para evitar que, nas tomadas muito abertas, o espectador perca “o detalhe”, e insiste em que, "se um aspecto é importante, você [leitor do manual], precisa se certificar de que o espectador o veja” (ibidem, p. 20) (acréscimo nosso), temos sempre atestada a presença da ideologia, a qual parece se mostrar como um tema delicado na abordagem técnica do autor.

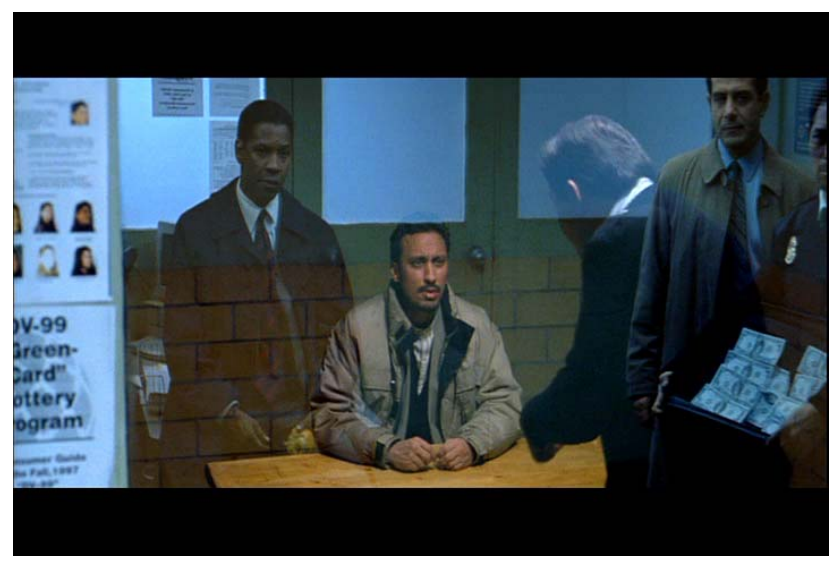

Figura 17: Interrogatório de Khalil Saleh.

\subsection{4 - Comunicando a incomunicabilidade}

Vimos até aqui que as representações sobre o outro nas quais aspectos de sua língua são tomados como elementos de identificação acabam enquadrando-o em uma categoria de indivíduos incomunicáveis. Isso pode ser observado na construção da imagem de um 
indivíduo que se mantém em total silêncio e que fala apenas através da violência de seus atos (SD2) mas que, quando fala, não responde a contento (do eu) ao que é perguntado (SD3) e nem é facilmente compreendido em razão da má pronúncia do inglês (SD4). A partir das leituras realizadas dessas representações, podemos assim observar que, quando o outro se inscreve falando em seu próprio idioma, há digressão no seu modo de se expressar, e quando se inscreve falando na língua do eu, há desentendimento. Tal constatação permite que consideremos a língua do outro representada sempre como "língua estrangeira”, porque “diferente” da língua dominante do filme. Na última seqüência discursiva que analisamos nesta parte do capítulo, queremos chamar a atenção para o aspecto que, no conjunto das representações observadas, reforça de maneira cabal todas as características já apontadas. Aqui, o outro novamente se inscreve na língua do eu, mas o tratamento dado à mesma, quando falada por aquele, a distancia de qualquer possibilidade de situar-se no mesmo nível da língua que é falada pelos outros sujeitos falantes, como poderemos observar.

\section{SD5}

Contexto: A primeira demonstração de que os terroristas do filme estão determinados a instaurar o medo na população de Nova York é a explosão de um artefato no interior de um ônibus, a qual, como já vimos, não fere nenhum dos passageiros. Após a falsa explosão que apenas serve de alerta para as autoridades, os supostos terroristas enviam uma mensagem em áudio para o FBI. Esta cena do filme inicia no momento em que Hubbard e outros agentes estão ouvindo atentamente a gravação da mensagem. Na segunda parte do trecho, um dos agentes mostra a Anthony Hubbard uma nova mensagem enviada provavelmente pelos mesmos remetentes, desta vez através de fax.

Gravação: This is our first and last warning. We expect our demand to be met. There will be no negotiation, no more communication of any kind. That is all.

Tina: Demand for what? You hear any demand?

Mike: Maybe it's a prank.

Danny: Some sense of humor.

Hubbard: Here's what I know. B.P., as in blue paint. Voice-altering technology. What do you think?

Frank: Available from the Sharper Image catalog. Last I looked, they didn't have an exploding paint bomb.

Hubbard: Still, the rhetoric sounds political. You think it's militia?

Tina: No, not their style.

Hubbard: Frank? 
Frank: Islamic Jihad aren't known for their sense of humor, and Hamas is raising so much money here. Why queer their deal?

Tina: Anyway, isn't green the color of Islam, not blue?

Hubbard: Another good point. Tina, rub these good points together. Come up with a composite of the suspects by the end of business today. Anita!

Anita: Yeah?

Hubbard: Run that against the mainframe for me, okay? Mike, lab analysis on the paint.

Mike: Report's not in yet, but we're checking to see if any blue paint was sold in quantity.

Hubbard: Good. Danny, how are the interviews going with the victims?

Danny: Not great.

Hubbard: Check the bus stops. Maybe somebody saw him get on.

$[\ldots]$

Agente: Excuse me, sir. I think you should see this. It just came in on the fax.

Hubbard (lendo): “Release him.” Release who? Who do we got?

Tina: Bill Clinton?

Hubbard: He didn't do it.

Mike: Charlie Manson?

Danny: Hamas guy was let go in April.

Frank: Under protest.

Hubbard: Yeah, but why be so coy about it?

Danny: You think it's a phony?

O sotaque marcado e a alteração da velocidade da gravação da mensagem produzem uma voz grave e artificial, cujo efeito metálico pode remeter à nossa memória de sons alienígenas freqüentemente explorados pelo cinema. Na única fala do trecho atribuída ao outro, este é representado como aquele que rejeita qualquer tipo de aproximação ou conciliação verbal. Toda negociação implica sempre uma comunicação bidirecional em que duas ou mais partes buscam diplomaticamente um acordo, mas aqui o inimigo a descarta de saída, fazendo com que seu dizer seja rebaixado à categoria do não-dizer, do incomunicável. É evidente que, conforme a ideologia da comunicação lógica e simétrica do filme, importa que o outro seja representado como um ser que fala de nenhum lugar e que a noção de mistério atribuído a seu dizer seja perpetuada em razão de interesses ocidentais, mas o que queremos apontar é o modo como se trabalha essa construção de imagem no diálogo para que 
o espectador se identifique com a posição dominante sem atentar, pelo menos como preocupação primeira, a tais operações lingüísticas dos enunciados.

Como a maior parte dos filmes normalmente trabalham no sentido de tornar invisível ao espectador a presença da manipulação ideológica, atribuindo sempre suas construções à liberdade e inventividade do artista, importa que as marcas de negação no dizer do outro não revelem o funcionamento de um discurso sobre a valorização da negociação. Diríamos que se trata do discurso do eu às avessas imposto ao outro, movimento que pode ser melhor esclarecido se tomarmos como referencial teórico o fenômeno da negação na teorização de Oswald Ducrot ${ }^{40}$. Segundo nossa leitura do autor, por trás de um enunciado declarativo negativo (por exemplo, Pedro não é amável), há dois atos ilocutórios distintos: $\mathrm{A}_{1}$ como uma asserção positiva relativa à amabilidade de Pedro (Pedro é amável), e $A_{2}$ como uma contestação de $A_{1}$, o que significa que $A_{1}$ e $A_{2}$ não podem ser atribuídos ao mesmo locutor. Tomando a fala atribuída ao outro no trecho analisado, se formulássemos uma paráfrase do enunciado "There will be no negotiation, no more communication of any kind”, aproximarnos-íamos do enunciado declarativo negativo “A negociação, como qualquer tipo de comunicação, não são meios de resolver conflitos”, o qual, remetido à noção de negação polêmica conforme a concepção polifônica de Ducrot, colocaria em cena um outro enunciado, que o outro, no filme, está contestando, a saber, o de que "a negociação e a comunicação são meios de resolver conflitos”. Existe, portanto, uma afirmação presente na negação, e essa afirmação é o que pode nos remeter ao discurso americano sobre a promoção das negociações, dos acordos - ou seja, da prática da diplomacia. É oportuno reproduzir aqui o texto celebratório na quarta capa da obra Diplomacy ${ }^{41}$, com suas 912 páginas, para que possamos compreender a dimensão dessa imagem de si:

Moving from a sweeping overview of history to blow-by-blow accounts of his negotiations with world leaders, Henry Kissinger describes how the art of diplomacy has created the world in which we live, and how America's approach to foreign affairs has always differed vastly from that of other countries (grifo nosso).

Além da constatação no nível lingüístico, as marcas de negação no trecho acima afirmando a resistência à negociação e à comunicação (no negotiation / no more communication of any kind) acabam atribuindo ao outro uma identidade tal que lhe impedirá

\footnotetext{
${ }^{40}$ DUCROT, O. El decir y lo dicho: polifonia de la enunciación. Barcelona: Paidós (tít. original: Le dire et le dit), 1986

${ }^{41}$ Obra de autoria de Henry Kissinger, New York: Touchstone, 1994.
} 
o ingresso em qualquer espaço organizado no mundo globalizado com sua ideologia da comunicação. A inscrição do outro no filme por meio da linguagem verbal ocorre, paradoxalmente, para negar-lhe esse mesmo direito de verbalizar suas idéias, visto que é representado como aquele que opta pela economia de palavras, anonimato e confinamento junto àqueles que partilham das mesmas idéias (note-se que o pronome 'we' na fala remete à idéia de grupo, ou célula).

A percepção (histórica, como vimos) do oriental árabe pelo Ocidente associada à idéia de mistério e imprecisão pode ser observada no trecho acima com base no próprio modo como a mensagem que abre a cena se estrutura. Nota-se que isso se dá com apenas quatro enunciados, e sem qualquer conjunção que os ligue. Em tal representação, essa mensagem telegráfica contrasta significativamente, como é possível observar, com o volume de informações presentes nas falas dos agentes do FBI que participam do diálogo. Laconismo e imprecisão, de um lado, eloqüência e precisão, do outro.

Considerando que há duas posturas principais sendo representadas (uma que rechaça a negociação e outra para quem o diálogo é primordial), importa que a língua de cada lado receba um tratamento especial que evidencie tal distinção. Ainda que a língua utilizada pelo outro na mensagem seja o inglês, estamos sempre chamando a atenção ao fato de que a mesma é representada como "estrangeira" para reforçar a dissociação com a língua daquele a quem temos nos referido como eu (ou narrador). Essas qualidades depreciativas acabam revelando, por oposição, a necessidade de apresentar uma outra língua de maneira celebratória - ou seja, a língua dos agentes deve apresentar, em sua forma, qualidades "positivas” tais como uma formulação elaborada, uma sonoridade agradável e “normal”, além de um traço importante identificando-a como a língua do falante nativo ou do imigrante já adaptado aos modos de falar do norte-americano, isto é, o sotaque. A mídia apresenta inúmeros casos em que atores imitam estrangeiros, como já tivemos oportunidade de abordar, porém o que interessa observar nessa análise em particular é o fato de que mesmo aspectos “mais externos” da língua, desvinculados do que o senso comum privilegia como comunicação ('o que se diz' mais que o 'como se diz’), produzem certos efeitos de sentido em um contexto sócio-histórico específico, pois passam a fazer parte de um conjunto de elementos definidores de uma determinada identidade que precisa ser reconhecida.

Observemos também que, enquanto a presença dos agentes no diálogo é atestada não apenas por suas falas, mas por estarem também presentes corporeamente, significando através de seus movimentos e expressões, a presença remota do outro sugere sua ausência, visto que suas palavras emergem de um toca-fitas ao redor do qual os agentes estão posicionados para 
ouvir a mensagem. O aparelho é mostrado em primeiro plano no início da cena enquanto a voz masculina alterada mecanicamente vai ocupando esse espaço do filme. A câmera vai aos poucos se distanciando do aparelho para mostrar a expressão de perplexidade dos agentes diante da misteriosa declaração. Após ouvirem as três últimas palavras da mensagem (That is all), Tina desliga o gravador e lança a pergunta que resume a inquietação do grupo: Demand for what?. Infere-se que não houve qualquer contato anterior, situação que, na rede de formações imaginárias, remete para as imagens construídas do outro em que este é percebido como carente de lógica e inconsistente no falar, como mostramos no Capítulo 3. Assim, dois aspectos combinados nessa representação, isto é, a tendência de não se mostrar e de não se expressar coerentemente, reforçam a existência de um modo ocidental de perceber esse outro em tempos atuais. É verdade que a ocultação do rosto do outro é um caso de elipse de estrutura bastante apropriado a este tipo de trama, pois o enredo prevê, por razões dramáticas, que o espectador deva ignorar um certo número de elementos que, segundo Martin (1990), “condicionam seu interesse pelo rumo da ação” (p. 78); porém, seu emprego nessa parte do filme parece revelar-se menos que uma convenção do gênero do que como um aliado de objetivos políticos em dado momento histórico.

Porque o espaço reservado ao dizer do outro é normalmente representado como ignorado, e porque nas vezes em que esse espaço é utilizado, o mesmo é freqüentemente ocupado por palavras de rebeldia e resistência, sua inscrição lingüística na trama parece querer condicionar o espectador a reconhecer a partir dessa rebeldia o caráter de imprescindibilidade de uma atitude oposta que valorize a comunicação e a transparência. A clareza dos sentidos que o filme pretende produzir depende da construção de um modelo que represente aquilo que contraria a atitude que convém celebrar. Temos mostrado que, no caso analisado, o modelo "negativo" se assenta na representação sobre o outro como incompetente para lidar com questões que só podem ser solucionadas com o diálogo. Sua mensagem no início da cena informa que não haverá negociação ou qualquer tipo de comunicação após um aviso que é, ao mesmo tempo, o primeiro e o último. Como se sabe, na retórica colonialista da atualidade sobre a inquestionável primazia da democracia em relação a qualquer outra forma de governo, muitas decisões políticas são justificadas por outros discursos que se produzem paralela ou entrelaçadamente para demonstrar a inadequação de algumas lideranças do chamado Terceiro Mundo. Grande parte do poder atribuído às grandes potências é representada menos pela ostentação de seu armamento do que pela exposição da aparelhagem de que dispõem para viabilizar a comunicação. Na seqüência de abertura de The Siege, essa exposição é bastante visível se observarmos a montagem das imagens que aproximam objetos 
contrastantes como a vista do deserto com beduínos conduzindo seus camelos e a tela de computador mostrando o mesmo deserto sendo rastreado por satélites para não perder de vista o inimigo fugitivo (FIGURA 18), e aqui também é possível verificar que o outro é sempre objeto do olhar de alguém que se representa com as condições necessárias para a vida no mundo contemporâneo. Essas representações no campo imagético possibilitam novas leituras do filme, como o fato de que, a despeito da representação sem reservas do poder de destruição do inimigo, a posição que este ocupa na hierarquia de valores do filme continua sendo inferior se comparada com outros valores atribuídos ao eu.
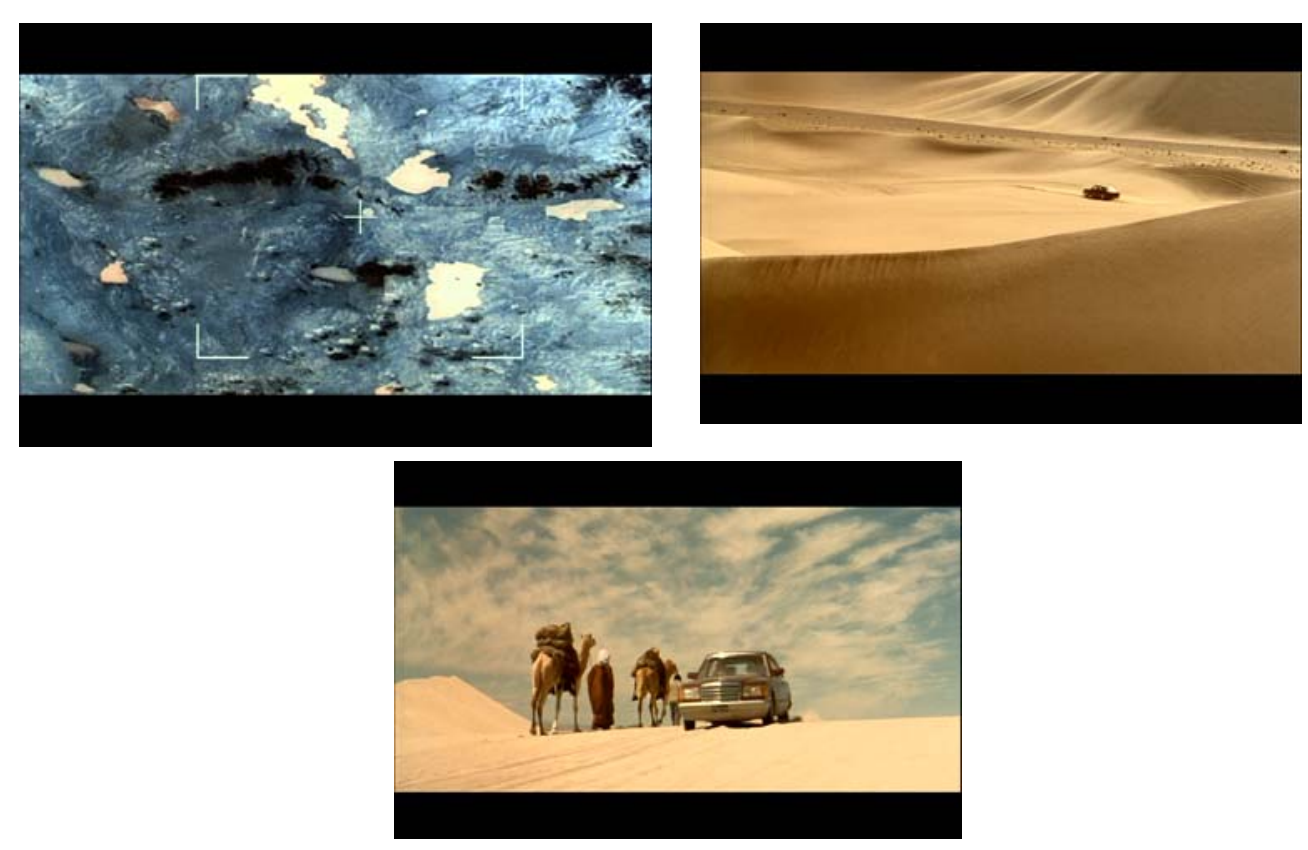

Figura 18: Veículo em que está o líder religioso que, mais adiante, é capturado pelo exército norte-americano. O trajeto do veículo no deserto é rastreado por satélite.

Em um segundo momento do trecho analisado, o outro se inscreve a partir de um fax que envia ao FBI, cujo conteúdo também é representado como deficiente em termos comunicativos. A mensagem telegráfica "Release him” intriga os agentes, colocando-os diante de um novo problema a ser resolvido: soltar quem? A inaptidão de uso da língua atribuída ao outro em várias ocasiões do filme aqui também reforça a idéia de uma suposta essência, como se a incompetência comunicativa fosse a marca do outro desde sempre. A leitura dessa segunda mensagem pelos agentes dá ocasião a comentários sarcásticos, novamente rebaixando o remetente, cujas poucas e incompreensíveis palavras são representadas como despossuídas de valor. Trazendo para a análise um aspecto da experiência contemporânea com determinados telejornais que abordam o terrorismo na sua relação com o Oriente Médio, é possível observar como o oriental árabe é sempre mostrado em 
aglomerações, bradando palavras que não são traduzidas para o espectador ocidental e queimando símbolos do Ocidente, jamais expondo seu ponto de vista individualmente a algum repórter. Assim, o filme se junta a outras manifestações midiáticas nas quais o imperativo parece ser o silenciamento do outro, atribuindo-lhe certa ininteligibilidade. Essas representações ao longo do filme estão em conformidade com uma mensagem apresentada na seqüência de abertura ${ }^{42}$, pois a ausência, insuficiência ou incoerência de palavras pressupõem a culpa de um réu que, por nada dizer em sua defesa que seja compreensível, se torna confesso.

Como nas seqüências discursivas analisadas anteriormente, aqui também é possível notar a contraposição criada quando se investe em representar a língua do outro com as qualidades que vimos apontando. Contrariamente ao investimento em atribuir ao dizer do outro qualidades de ambigüidade e estranhamento, as formas de dizer do eu são representadas como objetivas, claras e racionais, e todo o tempo do diálogo é ocupado com linguagem verbal. Não há momentos de silêncio (ausência de palavras) por parte dos agentes, e nota-se um esforço em tornar seus diálogos claros, dinâmicos e inquiridores, como atesta o uso freqüente da interrogativa para obter informações e sugestões com a técnica de brainstorming, bem como do imperativo, com comandos que são imediatamente reconhecidos e acatados. As respostas dos agentes precisam ser objetivas para que se justifiquem os comentários elogiosos do líder Hubbard (Another good point). Assim, de um lado, temos aquele que toma a palavra apenas para dizer que se opõe à negociação e, de outro, aquele que troca idéias (rejeitando-as ou aceitando-as), raciocina, pergunta, responde, caçoa no momento oportuno e dá comandos objetivos. Essa constatação nos leva a concluir que, da mesma maneira que há sempre uma “falta” na língua em sua materialidade lingüística (aquilo que ela não consegue exprimir, já que uma palavra necessariamente apaga outras tantas possíveis de terem sido usadas), pode haver um "excesso", caso nos concentremos apenas nos efeitos de sentido produzidos pela língua na sua "forma” e nos seus "modos”. Exemplificando, a própria “feição” do diálogo entre os agentes do FBI, no seu rápido movimento entre interrogativa, negativa e imperativo, é reveladora de um discurso sobre a celebração da negociação, da comunicação bidirecional, racionalidade e objetividade. É verdade, no entanto, que o que motiva os falantes desse diálogo a buscarem o sentido das coisas (You hear any demand? / You think it's militia? / Release who?) é o quebra-cabeça criado pelo outro sobretudo em razão de seu modo de se expressar representado como desconexo. As providências no sentido de solucionar o

\footnotetext{
${ }^{42}$ Referência a um trecho do pronunciamento de Bill Clinton por ocasião do ataque às torres Khobar em 1996, e que é utilizado no filme: “...the cowards who committed this murderous act must not go unpunished.”
} 
problema também dão ocasião à produção de um discurso sobre a importância do trabalho de equipe, em que o diálogo é visto como condição fundamental. Ainda que a liderança de Hubbard fique bastante patente no diálogo, espera-se produzir sentidos que favoreçam a percepção do líder como aquele que não pode prescindir da equipe para alcançar seus objetivos. O imperativo de suas ordens (Tina, rub these good points together / Come up with a composite of the suspects / Run that against the mainframe for me / Mike, lab analisis on the paint / Check the bus stops), como se nota, é acatado com reverência por parte dos membros da equipe sob seu comando.

Novamente podemos referirmo-nos à citação de Mariani (2004) mobilizada mais acima para traçarmos uma comparação dos modos como são representados o dizer do outro e o que é atribuído a si. No trecho da carta de Pero Vaz de Caminha selecionado pela autora, o escritor realça que a diferença entre os índios e o português, no tocante à língua, é que o primeiro "apenas fala”, ao passo que o segundo não apenas fala, mas pergunta, concorda, toma resolução (2004:47). Nas análises feitas nesta parte do capítulo, vimos que o outro, quando fala, não interroga, não deduz e nada supõe, pois importa que ele seja "falado" e representado. Podemos concluir a análise desse trecho invocando a idéia do que escreveu Marx em “O 18 brumário de Luís Bonaparte” e que Said (2007) resume colocando que, “se o Oriente pudesse representar a si mesmo, ele o faria; como não pode, a representação cumpre a tarefa para o Ocidente” (p. 51). O outro que temos analisado é sempre representado como incapaz de representar-se e falar sobre si, condição que acaba “justificando" a intervenção daquele que é o outro do outro.

\section{4 - Promovendo o reconhecimento sonoro e imagético da outra língua}

Nesta última parte da análise são analisadas três seqüências discursivas por meio das quais tentamos demonstrar que a identidade construída para o outro no filme é também pensada a partir do próprio nome de sua língua (ou daquela que lhe é atribuída) e de certos aspectos que a caracterizam. A recorrência com que essa nomeação se dá no filme nos leva, em um primeiro momento, a concluir que se vinculam determinados tipos de comportamento a um determinado idioma, relacionando, grosso modo, fazer/pensar algo a falar uma língua (e não outra). Sabe-se que todo idioma acaba se tornando um aspecto importante no conjunto de elementos que identificam os membros de uma determinada comunidade lingüística, tanto de 
dentro para fora da mesma (nós para os outros) quanto de fora para dentro (eles para nós), e no caso analisado, interessa observar como as representações sobre o outro parecem apropriar-se desse elemento identificatório para vincular sujeito e língua mais estreitamente.

\subsection{1 - O nome da língua em uma proposição explicativa: inserção incidente ou necessária?}

Iniciemos considerando a materialidade lingüística de um enunciado cuja compreensão pode contribuir para o entendimento de outros aspectos (não restritos ao lingüístico) que, ao longo do trabalho, temos demonstrado. Sua enunciação, dentro da seqüência de eventos da narrativa do filme, ocorre logo após uma bem sucedida operação do FBI que resulta na execução de três indivíduos (homens não nomeados) que fariam parte de uma célula de terroristas que teria iniciado seus ataques com a explosão de um ônibus (Bus 87 - cf. item 4.3.1) no Brooklyn ${ }^{43}$. A localização daqueles outros três integrantes do grupo é possível, como é mostrado no filme, com o método de escuta remota das conversas que os mesmos mantinham em seu apartamento. Na equipe do FBI que realiza essa escuta há agentes que dominam o idioma árabe, e são eles que fornecem dados sobre a rotina dos três suspeitos de envolvimento na explosão, como o fato de que passavam o dia todo assistindo televisão e comendo pizza, "nothing but pizza... pizza, pizza, pizza”. Essas conversas não são ouvidas, visto que a cena focaliza a ação dos agentes com os aparelhos de escuta. A partir dessa informação sobre a rotina do grupo, o plano foi montado: um dos agentes do FBI se disfarça de entregador de pizza, dirige-se ao local em que moram os três suspeitos e consegue fazer com que a embalagem da pizza (que contém em seu interior um dispositivo explosivo) entre na residência. As únicas palavras em inglês do suspeito que atende o pretenso entregador são ditas no momento em que aquele abre a porta (não totalmente, mas apenas o suficiente para que possa pagar pela encomenda): "Put it on floor" (FIGURA 19). Interessa observar a urgência da parte do cliente em trancar a porta, não apenas recusando o troco mas se mostrando completamente indiferente à tentativa de sociabilização do entregador, pois se trata já, conforme a leitura que realizamos, de uma representação sobre o outro como aquele que se indispõe à tentativa de integração mesmo no país que, como se pode compreender a partir da história do filme, o acolhe e até o influencia na questão de hábitos alimentares “ocidentais”,

\footnotetext{
${ }^{43}$ Bairro de Nova York que se destaca como uma região com presença significativa de imigrantes árabes.
} 
como o consumo de pizza. A imagem da cena mostrando o alimento no chão sendo imediatamente recolhido pelo cliente também parece remeter a situações de alimentação típica de alguns presídios (no caso, uma auto-reclusão), representação que produz efeitos de sentido de restrição do espaço e da chance do outro de se expressar, mas que não é, a rigor, imposta. Quando a câmera nos transporta para o interior da residência, que é representado, dentro dos padrões reconhecíveis de conforto, como um lugar pouco iluminado e com mobília desgastada (FIGURA 20), podemos ver os demais moradores vendo televisão e conversando animadamente em árabe, especialmente com a chegada da pizza. Essa animação é subitamente interrompida no momento em que é aberta a embalagem, pois é acionado o dispositivo que provoca uma pequena explosão, suficiente apenas para espantar os moradores e facilitar o arrombamento da porta e a entrada dos demais agentes do FBI, até então escondidos no hall do prédio. A partir daí inicia-se um tiroteio que resulta na morte dos três suspeitos. É na cena seguinte a essas seqüências, cuja situação mostrada (cenas do episódio da operação narradas por vozes em off de repórteres de telejornais) constrói um ponto de escuta ${ }^{44}$ momentaneamente dissociado das falas dos personagens principais, que é apresentada a notícia tranqüilizadora para a população de Nova York acerca da bem sucedida operação realizada pelo FBI:
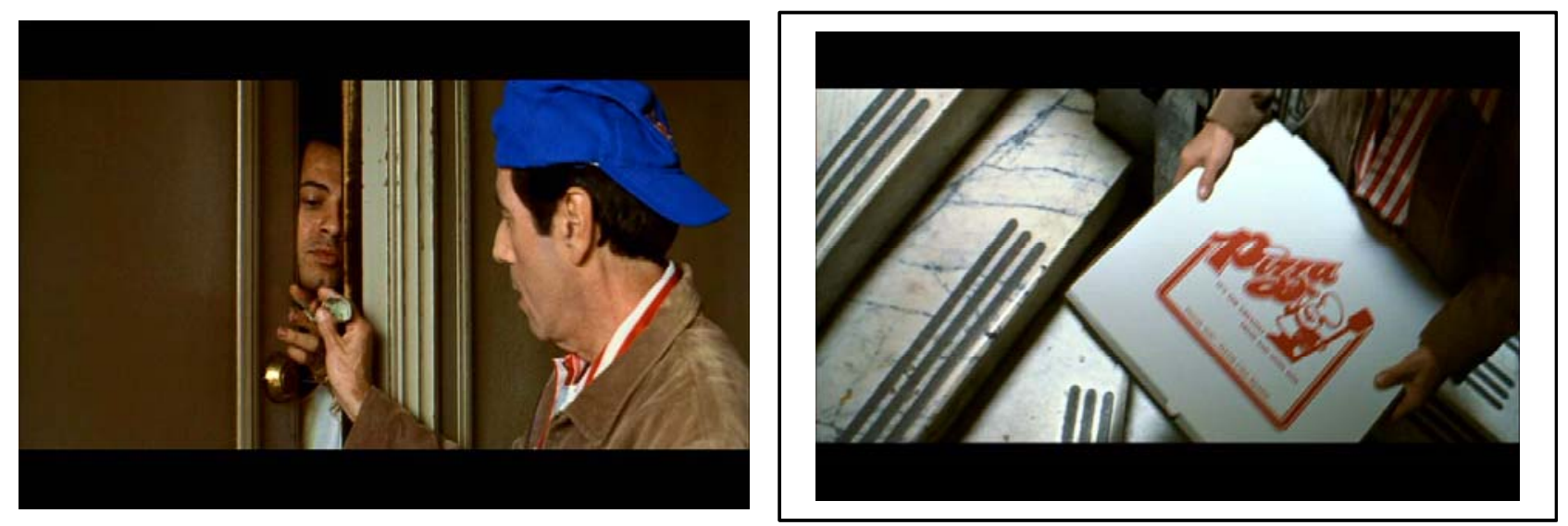

Figura 19

\footnotetext{
${ }^{44}$ Recurso usado para sugerir que determinado ponto é tomado como a origem do som, e que é obtido, por exemplo, aumentando-se o volume para indicar que a fonte sonora está mais próxima da câmera, e reduzindo-se o volume do som ou criando-se um efeito de reverberação para indicar maior afastamento. No caso analisado, o ponto de escuta criado indica maior afastamento não só pelo volume do som mas pelas imagens pouco definidas caracterizando imagens televisivas.
} 


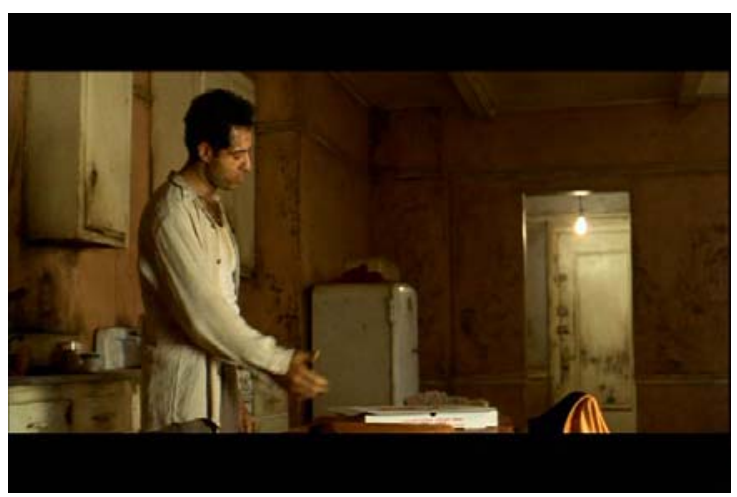

Figura 20

SD6

Repórteres: Three men were reported killed today after a shoot-out with the FBI in a quiet neighborhood in Brooklyn. [...] Already there are unconfirmed reports of a link between the victims, who were reported to be Arab-speaking, and the bombers of bus 87. FBI spokesman, Anthony Hubbard...

Anthony Hubbard [Denzel Washington]: We are presently following up on as many leads, and ... we're confident that we're on the right track. I think we're all happy that these criminals are off the streets, and we can all get on with our lives.

Gostaríamos de chamar a atenção primeiramente para a oração subordinada adjetiva “who were reported to be Arab-speaking” que destacamos nessa seqüência discursiva. Sabese que orações desse tipo são normalmente classificadas nas gramáticas como explicativas, visto que, como esclarece Bechara (1988), elas “encerram uma simples explicação ou pormenor do antecedente, uma informação adicional de um ser que se acha suficientemente definido, podendo ser omitidas sem prejuízo” (p. 118). Se nos propuséssemos a analisar a oração em questão sob a perspectiva da análise sintática, seguramente chegaríamos à mesma conclusão dos gramáticos, visto que a mesma poderia ser eliminada sem comprometer a compreensão do que restasse da formulação. Normalmente separadas do antecedente por uma pausa marcante representada na escrita pelo par de vírgulas que delimitam seu espaço no período, e, na fala, pela entonação, como se observa claramente no trecho analisado, essas orações com função de adjunto adnominal são então consideradas incidentes, acidentais - em outras palavras, desnecessárias. Assim, do ponto de vista da gramática, a oração que informa que os três homens mortos durante um tiroteio com agentes do FBI falavam árabe sobrevém, de certo modo, despropositadamente. Poderíamos especular que a ausência de outros dados 
mais relevantes sobre os mortos (seus nomes completos, idades e lugares de origem, por exemplo) justificaria, do ponto de vista da realidade fílmica, o acréscimo de uma informação “incidente” a respeito do idioma que eles falavam, já que se espera que o texto dos noticiários tentem, resumidamente, traçar um perfil razoável de quem é noticiado. Não é dessa maneira que nos propomos a tentar compreender esse enunciado.

Diríamos que, no enunciado em 6, a oração destacada não pode ser pensada como desnecessária apenas porque, lingüisticamente, sua supressão não prejudicaria o sentido da “proposição de base ${ }^{45 ”}$. É verdade que seu caráter incidente fica claramente marcado na fala do jornalista que, ao usar uma entonação diferenciada, evoca algo sobre o qual já se sabe a partir de outro lugar (no caso, o fato de que a língua desse outro é o árabe), visto que já na seqüência de abertura são exibidos elementos que remetem a essa língua (trilha sonora, caracteres e lugares), mas o que se observa aqui estaria relacionado ao que Pêcheux chama de “processo de sustentação”. Estamos diante, na verdade, de uma evocação de natureza ambígua visto que introduz, na aparente despretensão de sua explicação de caráter cultural, um outro pensamento. Essa oração (ou enunciação), que faz emergir no filme o sujeito ideológico, revela o compromisso, no momento histórico da produção da obra, de definir quem é o outro ameaçador, interpelando o espectador enquanto sujeito, ou condicionando-o a identificar-se com as posições ideológicas construídas pelo discurso do filme. O espectador deve reconhecer a presença da ameaça também a partir da nomeação de uma determinada língua.

Tem-se, portanto, que a oração destacada não se apresenta como uma explicação prescindível, visto que nas condições de produção do filme, o oriental árabe, com aquilo que pode representar em termos de ameaça ao Ocidente, ocupa um papel significativo e precisa “aparecer” de algum modo. A referência a seu idioma, ainda que não realizada de maneira assertiva como se nota nas modalizações que discutiremos mais adiante, entra como um elemento a mais na configuração da identidade do outro ameaçador que é percebido como recluso e avesso ao diálogo. Essa língua que o narrador não reconhece ao certo (porque invariavelmente usa modalizadores) passa a identificar também o sujeito que se opõe à transparência e à tentativa de integração proposta pelo Ocidente.

Pois bem, a análise que vimos realizando se baseia na noção de "efeito de sustentação" de Pêcheux, segundo a qual a intervenção da proposição explicativa como um suporte do pensamento contido em uma outra proposição ocorre por meio de uma relação de implicação entre duas propriedades, $a$ e $b$ (PÊCHEUX, 1988:110). O efeito de sustentação corresponderia

\footnotetext{
${ }^{45}$ Informações baseadas na parte 3 do Cap. 2 da obra de Pêcheux "Semântica e Discurso: uma crítica à afirmação do óbvio”: Articulação de enunciados, implicação de propriedades, efeitos de sustentação.
} 
à relação “o que é $a$ é b”, visto que é essa relação que articula as proposições constituintes. Retomando o nosso exemplo, poderíamos nos aproximar da seguinte construção parafrástica: “Já temos informações de que as vítimas do FBI pudessem falar árabe. As vítimas estariam vinculadas ao grupo que explodiu o bus 87.” No caso, a proposição a se refere a "ser um dos homens executados pelo FBI [vítimas]” e a proposição $b$ se refere a “falar árabe”. Portanto, se algum indivíduo perseguido pelo FBI fala árabe, está vinculado a alguma célula terrorista. Com a aplicação dessa teorização, fica mais claro observar que a explicativa, contanto pudesse ser suprimida em uma análise sintática, aqui intervém como "uma evocação simulada, que introduz, sub-repticiamente, um novo 'pensamento'” (ibidem, p. 111). Pêcheux destaca a palavra “pensamento” para assinalar que empresta um termo originalmente empregado por Frege, para expor seu conceito dentro de uma perspectiva discursiva, e é interessante atentar para a conclusão do primeiro autor a propósito desse "processo de sustentação" como constituindo uma espécie de "retorno do saber no pensamento". A partir dos exemplos citados em seu Semântica e Discurso, poderíamos dizer que, no enunciado sob análise, o narrador não “ensina” ao espectador que o outro fala a língua $x$, mas o "faz pensar corretamente” sobre algo que já sabe a partir de uma tradição orientalista que Hollywood, a seu modo, procura perpetuar, ao mesmo tempo em que atualiza acontecimentos do momento histórico em questão. Pode-se argumentar que, no trecho analisado, o narrador estaria dizendo ao espectador do telejornal criado pelo filme: "Estou relatando o episódio da operação do FBI, mas não tenho como omitir que as vítimas falassem árabe, pois essa é uma informação relevante neste momento”. Essa representação sobre o outro no nível da linguagem verbal se fortalece quando consideramos também o apelo imagético dos elementos que caracterizam a cena anterior mostrando a operação do FBI: o confinamento no apartamento sombrio, o cuidado de não abrir a porta completamente e a fisionomia impassível ao ter de interagir com o entregador de pizza. O conjunto desses elementos configura uma linguagem que produz significado, e é nesse ponto que Nichols (1981) enfatiza que "we need to be able to identify these ideological elements, to discover the aspects of representation that embody them, to understand the place set out for us within such processes” (p. 2). Como argumentamos, esse lugar desejável do espectador é aquele da identificação com a posição do agredido, apesar do grau de violência empregado para seu extermínio, o qual deve ser visto como necessário. 


\subsection{2 - As marcas de modalização no falar sobre a língua do outro}

O segundo momento em que a língua do outro é nomeada no filme ocorre em uma situação de grande tensão durante as cenas que mostram o seqüestro do Bus 87 por indivíduos que em momento algum da cena são mostrados ou ouvidos. Agentes do FBI conseguem se comunicar por telefone com o motorista que, mesmo em poder dos seqüestradores, consegue fornecer informações sobre aqueles que mantêm a ele e a todos os passageiros como reféns. O terceiro momento em que essa nomeação se dá (SD8) está inserido em um longo pronunciamento televisivo do general William Devereaux (Bruce Willis) em que anuncia oficialmente a determinação do governo de decretar estado de lei marcial em Nova York como uma medida cabal para solucionar o problema dos atentados na cidade.

\section{SD7}

Frank Haddad [agente do FBI]: The driver's name is Larry Kaiser. He says they got explosives strapped to their chests... they got automatic weapons and he thinks they're speaking Arabic. [...]

\section{SD8}

William Devereaux: Today, [...] I am declaring a state of martial law in this city. To the best of our knowledge we are opposed by no more than twenty of the enemy. He's hiding among a population of roughly two million. Intelligence tells us that he is most likely Arab-speaking, between the age of 14 and 30 , narrowing the target to 15,000 suspects. We can further reduce that number down to those that have been in this country less than six months. [...] If you are one of these young men, you can hide among a population of similar ethnic background. Unfortunately for you, you can only hide there, and that population, in the classic immigration pattern, is concentrated right here in Brooklyn. We intend to seal off this borough, then we intend to squeeze it. This is the land of opportunity, gentlemen - the opportunity to turn yourselves in. After sundown tonight, any young man fitting the profile I described who is not cooperating will be arrested and detained. There is historically nothing more corrosive to the morale of a population than policing its own citizens, but the enemy would be sadly mistaken if they were to doubt our resolve. They are now face-to-face with the most fearsome military machine in the history of man, and I intend to use it and be back on base in time for the playoffs. Thank you for your time.

Como se observa, estamos destacando o emprego de dois tipos de modalizadores em ambas as formulações (he thinks / he is most likely) pois gostaríamos de chamar a atenção 
para o que essas escolhas lexicais podem revelar a propósito do estudo realizado sobre as representações sobre o outro a partir do aspecto de sua língua. É através da modalização que o sujeito falante determina o seu grau de “compromisso” com uma proposição, e Fairclough (2002) ilustra bem esse fato com exemplos objetivos mostrando que podemos tanto afirmar categoricamente que “a terra é plana” como fazer isso menos assertivamente dizendo que "a terra pode ser/provavelmente é/possivelmente é plana” (p. 159). Segundo nossa leitura do autor, sempre haverá, no enunciado, alguma marca lingüística indicando o grau de "afinidade” com a proposição por parte de quem a produz, e ambos os casos analisados apresentam marcas que, embora não pertencentes aos tipos tradicionais de verbos auxiliares modais como must, may e should, no caso do inglês, cumprem também esse papel dentro da língua. Fica claro que o uso da modalização também cria um certo distanciamento entre aquele que enuncia e aquilo que está sendo enunciado, e vale lembrar que, se não é possível atribuir a “produção” de enunciados a personagens de filme, é o narrador (conforme definido na análise anterior) que se distancia daquilo que a narrativa propõe ao espectador. Por exemplo, o motorista do ônibus, que apesar de ser nomeado (SD7) também não é mostrado e nem ouvido, não afirma que os seqüestradores do veículo falem árabe (Larry Kaiser 'acha' isso apenas), logo, tanto ele quanto o narrador não se comprometem totalmente com a proposição, na ilusão talvez de produzir um efeito de sentido de neutralidade ideológica. Desse modo, temos um caso de duplo distanciamento: na materialidade lingüística (com as próprias marcas de modalização) e nas materialidades imagética e sonora (com a ocultação do rosto e silenciamento da voz do personagem a quem se atribui a informação que o agente Frank apenas reproduz). Tanto em 7 quanto em 8, outro elemento que marca esse distanciamento é a própria pessoa do discurso reportado, pois em nenhum dos casos temos uma modalização que Fairclough chama de "subjetiva" 46 , isto é, aquela em que o grau de afinidade do "falante" com a proposição é mostrado no discurso, como ficaria, supostamente, em uma fala do personagem do tipo “I think they’re speaking Arabic”. É verdade que essas falas se justificam pela própria natureza do cinema, o qual trabalha com o suspense, com as elipses, mas em ambos os casos analisados, importa notar que é sempre uma "terceira pessoa” que intervém para informar que a língua falada pelo outro apenas parece ser o árabe: em 7, essa pessoa é o motorista do veículo; em 8, o próprio FBI.

\footnotetext{
${ }^{46}$ Vale notar que o tipo de modalização que Fairclough, por oposição, chamaria de “objetiva” (They're speaking Arabic) não encontra, a rigor, um fundamento do ponto de vista da $\mathrm{AD}$, visto que esta considera ambos os exemplos como subjetivos.
} 
Authier-Revuz (2004), quando aborda o tema das aspas, também trabalha a questão dos sinais de que o locutor pode se servir para marcar, em seu dizer, um distanciamento de certas palavras que produz, especialmente na escrita. Também a partir de exemplos simples como "Ele disse: 'I don’t mind’”, a autora expõe vários aspectos relativos ao ato de manter à distância as palavras, como o fato de que as aspas marcam um outro ponto de vista (p. 217) ou, de maneira mais abrangente, um "encontro com um discurso-outro" (p. 229). Caso semelhante de remissão a um discurso-outro também ocorre com o discurso indireto, no qual o locutor se comporta, segundo essa autora, como "tradutor" que, ao fazer uso de suas próprias palavras, remete a um outro como “fonte do ‘sentido' dos propósitos que ele relata” (p. 12). No caso analisado em 7, por exemplo, é o motorista do veículo, duplamente colocado à distância, como vimos, que é tomado como responsável pela informação acerca do idioma dos seqüestradores. Nesse caso, especificamente, é possível ainda argumentar que a emergência do sujeito se torna mais "visível”, a exemplo do que notamos também com a oração explicativa em 6. Expliquemo-nos: o enunciado "and he thinks they're speaking Arabic”, a nosso ver, rompe subitamente uma seqüência de informações sobre os explosivos e as armas em poder dos seqüestradores, não estabelecendo rigorosamente uma coesão textual com a informação acerca do provável idioma. Estamos chamando a atenção para a emergência do sujeito aqui sobretudo no ponto em que argumentamos que esse é um elemento da identidade do outro que o filme investe em fazer aparecer.

Pode-se especular que a escolha por essas marcas de modalização no fio do discurso conduzido pelo filme se torna uma operação lingüística de que o narrador se serve para contar "sua história” de um modo mais distante, na tentativa de produzir um efeito de sentido que traduza a suposição de que isso que ele diz sobre o outro não faz parte de seu seu discurso. Parafraseando Authier-Revuz, diríamos que em ambos esses casos de remissão a um discursooutro, o narrador, caso pudesse, se defenderia afirmando que diz o que diz sobre o outro apesar de saber que é inconveniente fazê-lo (p. 220), uma vez que não pode afirmar categoricamente que o idioma falado pelos seqüestradores seja o árabe. O uso desses modalizadores tornar-se-ia um modo de os produtores do filme se defenderem caso fossem criticados devido ao rebaixamento da imagem do árabe.

Observando mais detidamente a SD8, não obstante o cuidado da modalização no sentido de afastar de si a responsabilidade pela informação acerca da língua do outro, aquilo que não é afirmado se torna, ainda assim, uma das condições para que todo indivíduo que se encaixe no perfil traçado por William Devereaux seja detido. É o que se conclui a partir destes dizeres do personagem: If you are one of these young men [mesmo que não tenhamos certeza 
sobre o idioma que você fala] any young man [sem exceção] fitting the profile I described who is not cooperating will be arrested and detained. É verdade que o general Devereaux é representado no filme como rival de Anthony Hubbard no que concerne ao posicionamento político, mas, ainda que essa representação xenófoba seja compreensível nesse instante do filme se levarmos em conta a configuração do personagem Devereaux, o conjunto das representações sobre o outro ao longo da história sinalizam para uma mesma retórica: a da rejeição à diferença, tanto em Devereaux quanto em Hubbard.

Até aqui temos nos concentrado na análise da materialidade lingüística de enunciados que não chegam a ponto de afirmar que o outro fale árabe, mas como lidar com essa referência ao idioma estranho quando isso não se dá verbalmente (aqui entendido como materializado na fala do personagem), mas imageticamente? É o caso, por exemplo, da longa cena de três minutos em que um dos suspeitos de pertencimento ao grupo de terroristas começa a ser monitorado pelo serviço de inteligência enquanto caminha pelas ruas do Brooklyn. Sua caminhada inicia logo após descer de um táxi em frente a um estabelecimento comercial cuja parede de vidro, mostrada em primeiro plano, exibe grandes caracteres em árabe (FIGURA 21). Na calçada por onde caminha sem notar a presença de uma equipe de agentes disfarçados e distribuídos em pontos estratégicos com todo o aparato de comunicação remota, também são mostradas, em primeiro plano, placas de preços com caracteres árabes promovendo artigos de vestuário vendidos pelos ambulantes (FIGURA 22). Quando esse suspeito se encontra com um companheiro, a conversa que iniciam após se saudarem ocorre exatamente em frente a outro estabelecimento identificado por letreiros que também exibem caracteres árabes (FIGURA 23). Em outro momento, um dos agentes do FBI que participa da vigilância aparece caminhando por um ponto da calçada de onde se avista ao fundo cartazes de vídeos e CDs árabes (FIGURA 24). É verdade que a presença desses caracteres se ajusta perfeitamente à locação escolhida para a cena (caso fosse a região de Chinatown, não causaria estranheza a profusão de placas escritas em ideograma), porém não se pode negar que esse cuidado cenográfico em "Nova York Sitiada” funcione ideologicamente, sobretudo em razão da recorrência com que o filme procura levar seu público a identificar-se com uma posição de subjetividade construída por meio dessas representações. 


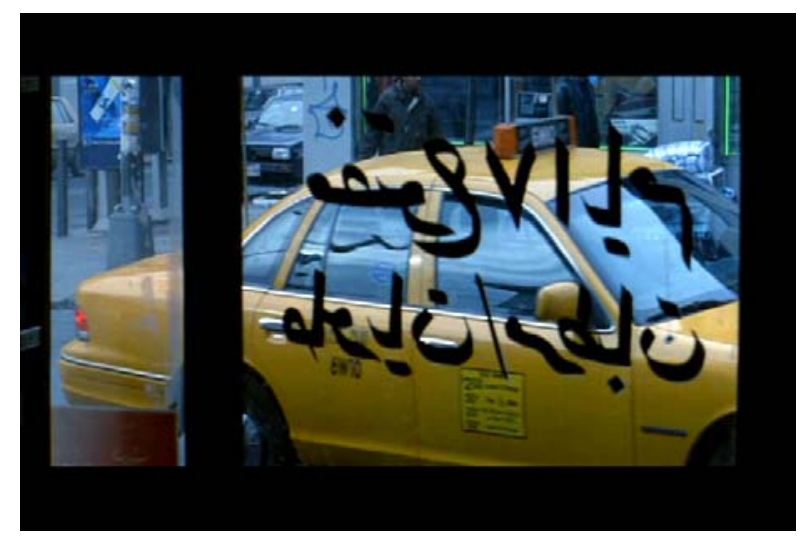

Figura 21

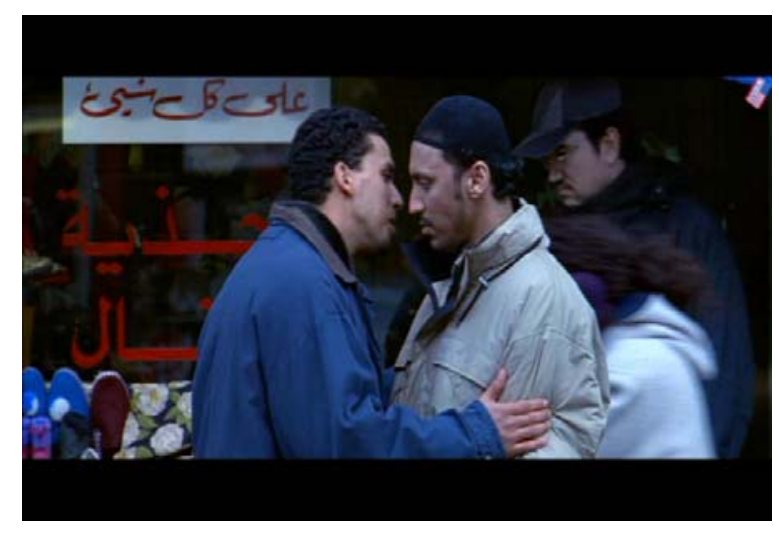

Figura 23

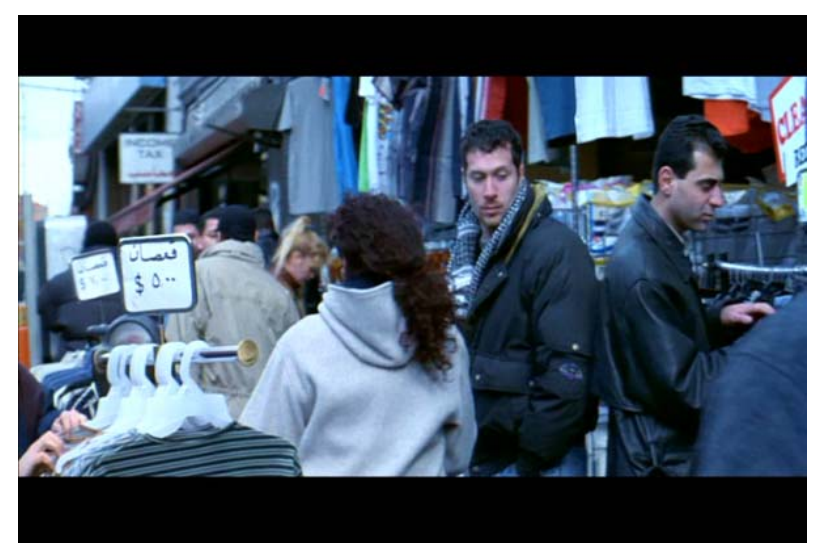

Figura 22

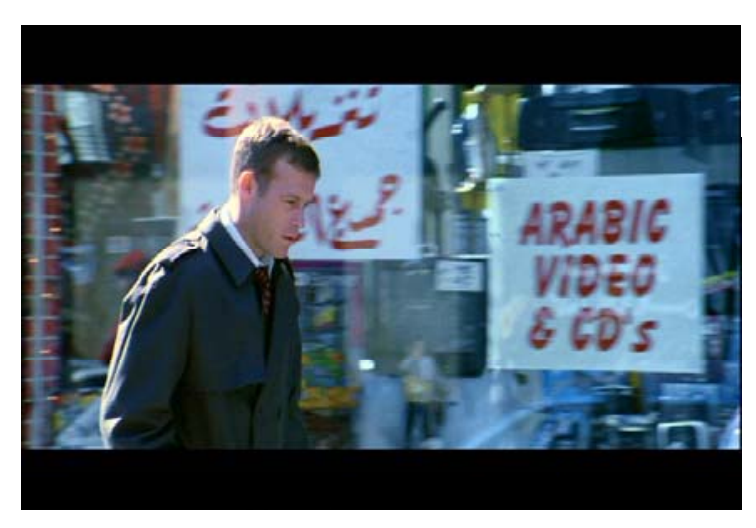

Figura 24

Chamamos agora a atenção para o fato de que, nesses quatro momentos apontados, é possível retomarmos a discussão acerca do caráter incidente (ou não) da informação adicional, aqui atestada pela presença dos caracteres que remetem à língua do outro. Uma vez que nesses casos também caberia perguntar se a eliminação das “explicativas” (os caracteres) comprometeria o entendimento da cena como um todo, tomamos a liberdade, para fins ilustrativos, de interferir digitalmente nos quatro fotogramas, com o auxílio de um software, apagando os caracteres em árabe dessas imagens, resultando no efeito que mostramos na seqüência (FIGURA 25). À esquerda, reapresentamos os fotogramas como aparecem no filme; à direita, como ficam sem a referência ao idioma árabe: 

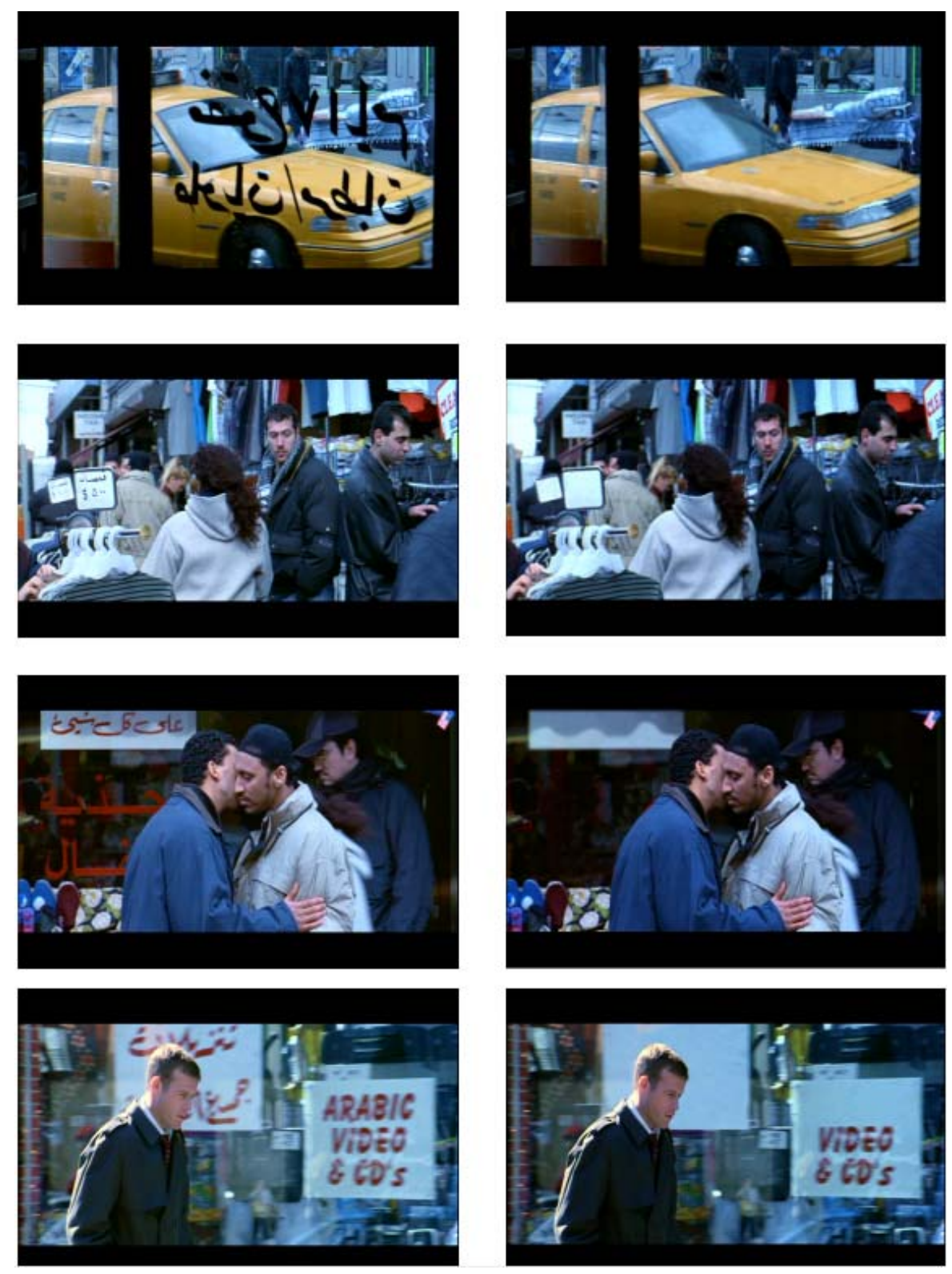

Figura 25

É importante observar também que, em nenhum desses quatro momentos, o outro é representado "falando"; mesmo na Figura 23, em que os dois suspeitos conversam afetuosamente, nenhum som deles se ouve, uma vez que são observados à distância pelos agentes. O ponto de escuta, neste caso específico, é a conversa que os agentes Anthony Hubbard e Frank Haddad mantêm no veículo enquanto acompanham os movimentos do suspeito à distância. Ainda que esse distanciamento esteja justificando a elipse do som da conversa do suspeito com seu companheiro, argumentamos que essa operação acaba favorecendo o silenciamento do outro.

A presença dos caracteres em árabe nos fotogramas da coluna esquerda (FIGURA 25) poderia ser considerada, até certo ponto, uma intervenção semelhante à que ocorre com a oração “who were reported to be Arab-speaking” na SD6 em um "processo de sustentação”, 
como vimos, e se compararmos cada par de fotogramas, podemos concluir que se trata também de um "retorno do saber no pensamento". Ora, se entre outras imagens possíveis no processo de montagem da seqüência, são escolhidas com freqüência aquelas que trazem tais caracteres, é porque, servindo-nos da mesma citação de Leibniz ${ }^{47}$ com que Pêcheux ilustra esse "retorno", elas (tais imagens) “não dizem nada de novo [porque a referência ao idioma do outro ocorre ao longo de todo o filme por outros meios também], mas nos fazem pensar corretamente naquilo que sabemos [algo do tipo 'convém que o espectador reconheça também nesses caracteres a identidade de uma certa alteridade']” (apud PÊCHEUX, 1988:111).

Permitindo-nos uma certa digressão do objeto principal de estudo (o aspecto da língua), mas ainda assim inseridos diretamente na questão da construção de identidade, julgamos relevante observar, a propósito dessas quatro imagens que exibem caracteres em árabe, que aqui parece se repetir um fenômeno apontado por Torres (2001) em seu artigo sobre o filme Falling down (Um dia de fúria, 1998). A autora observa, em uma análise bastante fundamentada, que a circulação de signos estrangeiros na "paisagem” de cidades como Los Angeles e Nova York (e que esses filmes costumam destacar) serve "para desestabilizar esta identidade construída [de americanness], e que isto cria um desejo de reforçar, ou reiterar o que significa ser americano” (p. 205). Embora Torres esteja aqui se referindo a uma provável crise de identidade do americano por ter de conviver com a concorrência de carros, roupas e brinquedos fabricados em outros países, é interessante observar que a exibição desses "signos” (como ocorre com os caracteres em árabe no nosso corpus) revela muito mais que a preocupação despretensiosa do cineasta em ambientar a cena de seu filme. Sem nos aprofundarmos em questões de psicanálise, mas não descartando sua contribuição para o estudo, poderíamos aqui considerar a noção de recalque como uma possibilidade de leitura dessas imagens. A exibição de tais signos estrangeiros se presta para identificar mais rapidamente quem é a antítese da sociedade norte-americana do momento histórico em questão, mas também para demonstrar o desconforto dessa sociedade por ter de lidar, por exemplo, com imigrantes que povoam "seus” bairros falando línguas incompreensíveis e que desestabilizam a idéia de liberdade que a mesma busca sempre valorizar, já que deve acolhê-los. A contradição estaria no fato de que, se por um lado essa língua é representada como diferente graficamente, desconhecida e distante, como atesta o uso das marcas de modalização no discurso, por outro, acaba sendo mostrada próxima demais

\footnotetext{
${ }^{47}$ LEIBNIZ, G. W. F. Novos ensaios sobre o entendimento humano. São Paulo: Abril Cultural, 1984, p. 347, apud PÊCHEUX (op. cit, p. 111).
} 
daquele que comanda essas representações, como confirmam os primeiros planos dos quatro fotogramas em questão.

Em todas as situações analisadas até aqui nessa parte, a língua do outro é mostrada, ora através da nomeação direta, como vimos na materialidade lingüística em 6, 7 e 8, ora por meio da exibição de caracteres que parecem fixar, na paisagem cosmopolita contemporânea, os limites entre o Ocidente e o Oriente. Atingimos agora um ponto da análise em que poderíamos também perguntar: o que dizer sobre a língua com a qual o narrador se identifica? Em nenhum instante é nomeada outra língua além do árabe, mas é evidente que o inglês está pressuposto, pois o sentido que se espera produzir ao nomear a língua do outro pressupõe a existência de uma língua que serve de parâmetro para, como podemos concluir, produzir representações de rebaixamento sobre a outra. $\mathrm{O}$ inglês acaba sendo associado àqueles cuja missão é garantir a paz da sociedade com o extermínio do inimigo. Nas SDs 6, 7 e 8, o rebaixamento do outro ocorre por meio de termos como bombers, criminals, explosives e enemy, enquanto aquele que não fala árabe é percebido a partir de palavras como confident, right track, intelligence e land of opportunity. Historicamente, apesar da importância do idioma árabe, como já foi assinalado, essa língua também passou a ser pensada, em alguns setores do meio acadêmico, como um idioma caracterizado pela presença de muitos termos que remetem à violência. A título de ilustração, Said (2007) informa que alguns alunos da Universidade de Columbia (Estados Unidos) afirmaram, em um guia de cursos por eles publicado em 1975 sobre o curso de árabe, que "uma de cada duas palavras nessa língua tem a ver com violência, e que a mente árabe, como tal, é 'refletida' pela língua, é incansavelmente bombástica” (p. 384). Uma afirmação como essa, que rebaixa sem reservas e critérios a língua árabe, se filia claramente ao orientalismo que Said investigou, porém, mesmo em um estudo mais recente com um objetivo declarado de valorizar a cultura árabe, do ex-diplomata Mark Allen, que atuou em países do Oriente Médio, encontramos representações sobre essa língua que também remetem ao mistério, como se um idioma pudesse, desde sempre, ser destinado à incompreensão. Segundo Allen (2006), mesmo para “eles” (povos árabes), é difícil o aprendizado do idioma árabe, e o autor esclarece, por exemplo, “que os textos em língua árabe são a parte mais difícil nos exames finais do secundário” (p. 142), em conseqüência, afirma o autor, da criação de uma sofisticada gramática formal a partir de estudos sagrados que desenvolveram análises minuciosas de todos os traços lingüísticos do Corão. Por esse motivo, segue Allen, "são poucos os árabes que a dominam” (op. cit). Embora se trate de afirmações que não fazem parte de algum projeto ideológico que vise a estigmatizar os povos árabes, enunciados como esse acabam produzindo certos efeitos de sentido como o de que 
possa haver outras línguas mais fáceis. Não se leva em consideração que qualquer língua sempre apresentará “dificuldades” a determinados grupos da sociedade em questão. É verdade que, no caso da língua inglesa, sejam freqüentes representações da mesma como sendo fácil, não complicada e acessível em virtude da conjugação verbal, por exemplo, mas sabemos que tais declarações se baseiam em mitos do mesmo modo como ocorre com as línguas classificadas de "difíceis”. Ainda assim, é interessante observar o que Allen esclarece a respeito de uma particularidade do vocabulário desse idioma ao pensar o vocábulo "leão". Segundo o autor, o número de palavras que se referem a esse animal é expressivamente superior ao número de palavras associadas às flores, por exemplo, já que a “jardinagem”, pela razão óbvia da falta de água no deserto, não constituía um grande interesse popular (p. 146) entre os povos desses lugares. Contanto úteis do ponto de vista da pesquisa, esses esclarecimentos também cooperam no sentido de reforçar imagens construídas pelo Ocidente (habituado a flores como símbolo de harmonia) do Oriente como árido e imprevisível como as feras do deserto. Essa exposição nos autorizaria a traçar duas comparações a partir da leitura das representações sobre a língua do outro no filme que acabam, por oposição, representando também a língua do eu. Poderíamos dizer que a língua do outro está associada às formas de perceber o deserto, o mistério e o leão enquanto tipos de ameaça (falta de água, tempestades de areia e ferocidade felina), ao passo que a língua do eu está associada às formas de perceber as flores com aquilo que simbolizam em termos de fragilidade, beleza e harmonia. O eu é representado no filme, seguindo a tradição maniqueísta hollywoodiana, como aquele que deve garantir a paz na terra, portanto, sua língua também entra no conjunto de qualidades a ele atribuídas. 


\section{CONSIDERAÇÕES FINAIS}

Nosso estudo foi idealizado já a partir de um pressuposto dentro da retórica do discurso colonialista, de acordo com a qual todo aquele que se enquadra na categoria de alteridade (o estrangeiro, 'inferior', diferente, dependente, não necessariamente rival) deve aparecer como um corpo silente, visto que seu dizer é considerado, a priori, como despossuído de valor ou inconveniente. E essa alteridade aparece nos discursos colonialistas porque sua existência, enquanto contraponto dos valores com os quais o sujeito desses discursos se identifica, se torna fundamental para a legitimação e perpetuação dessa mesma retórica. Como afirma Wagner (1997), "sólo llegan a formarse culturas si se establece una comparación entre lo que tienen de propio y algún Otro que ellas no son” (p. 84). Nosso objetivo não foi, portanto, confirmar a existência de tal fenômeno, mas demonstrar de que maneiras o mesmo se dá em um produto cultural contemporâneo. A partir desse pressuposto, formulamos duas perguntas que pudessem nos direcionar, sobretudo no ponto do percurso em que nos dedicamos especificamente à análise do corpus: Por que mecanismos (considerando a interpelação do indivíduo em sujeito pela ideologia) esse silenciamento do outro acaba aparecendo de maneira espontânea e natural? Que identidades são construídas para cada um dos pólos envolvidos nessas representações, considerando os efeitos de sentido produzidos por e com esse silenciamento?

A análise mostrou que o "eu” (ao qual outras vezes nos referimos como narrador) se serve de um imaginário já construído do oriental árabe para conferir naturalidade à representação sobre este como um corpo silente, servindo-se também das características do próprio cinema quando pensado na sua relação com o compromisso de entreter, mostrando o belo e o exótico. Imagens de deserto, monocromáticas, compostas em grande parte por um único elemento, a areia, intervêm na condição de símbolos carregados de significado, como o próprio silêncio do lugar, a aridez e a inacessibilidade. A esses símbolos somam-se trabalhos de câmera, critérios de enquadramento, opção por recursos como a câmera lenta, a trilha sonora, entre outros que são próprios do meio. A imagem do corpo se movimentando ao longo do deserto, ou de indivíduos conversando em algum local distante daquele que é tomado como ponto de escuta acaba justificando elipses das já limitadas ocasiões em que o outro pudesse ser representando em uma situação que envolvesse linguagem verbal. O ponto de vista privilegiado nas cenas é determinado não apenas a partir da materialidade lingüística das 
partes dialogadas (o eu como possuidor de um maior repertório de palavras), mas pelo ponto de vista criado pelo próprio modo como a câmera focaliza um personagem e outro.

A análise mais detida das representações sobre o outro não impediu que também fossem observadas, ao mesmo tempo (e inevitavelmente, como nos parece), as representações sobre o eu, o narrador. Em todos os momentos da análise constatou-se a construção de tipos contrastantes de identidade, fixando um lugar para cada um dos pólos envolvidos. Concentrando-nos sempre em elementos dessas representações que pudessem estar mais diretamente relacionados com as maneiras de dizer e de se expressar, foi possível observar que o silenciamento do outro depende constantemente de situações que o justifiquem, e é nesse ponto que uma certa previsibilidade (já que partimos do pressuposto de que o outro sempre intervém como corpo silente na retórica colonialista) apresenta dados importantes do ponto de vista da contribuição que a análise pode oferecer. Para que o eu possa representar-se como defensor da democracia e dos direitos humanos, favorável ao diálogo e à negociação diplomática, precisam ser criadas situações nas quais o outro seja "naturalmente" representado como contrário a todas essas qualidades. A análise mostrou que isso é possível por meio de representações sobre o outro como econômico na produção de palavras, indisposto a mostrar-se fisicamente, pouco competente nas vezes em que se comunica em inglês, digressivo quando expõe suas idéias e indisposto a sociabilizar-se com aqueles que tentam uma aproximação. Na maior parte das situações analisadas, o espaço reservado para que o outro fale é representado como existente (ele poderia falar, se quisesse), porém, essa oportunidade é representada como ignorada ou negligenciada.

Já considerando um contexto mais amplo, exterior às observações que os trechos nos possibilitaram (mas evidentemente a partir deles), a análise nos leva a concluir que há um movimento, sobretudo em tempos atuais, no sentido de construir dois tipos de identidade contrastantes: uma que fixa o sujeito que busca constantemente integrar-se em todas as esferas por meio de uma linguagem aceitável, coerente e universal, e outra que fixa o sujeito que permanece indiferente a essas mesmas tentativas de integração e globalização, opondo-se à comunicação universal e ocultando-se de acordo com suas idéias e crenças. Contrastam-se sempre dois modos diferentes de relacionar-se com o mundo pela linguagem, e, a propósito do filme, é possível considerar até mesmo a construção de identidade de um sujeito que se relaciona com o mundo de uma maneira ocidental, e de outro que o faz de uma maneira oriental. O modo ocidental de se relacionar com o mundo é aquele que está vinculado à razão e que exclui qualquer possibilidade de harmonia com um modo representado como antiquado, obsoleto, próprio de uma época passada e inferior. 
A discussão desse aspecto da representação sobre o outro nos parece pertinente, portanto, sobretudo em um contexto no qual cada vez mais se valoriza a comunicação eficiente. Como bem nota Payer (2005) a propósito da demanda de conhecimento e domínio de múltiplas linguagens, tecnologias e situações discursivas a que o sujeito contemporâneo está exposto, há uma urgência no sentido de que:

[S]ejamos capazes de uma certa performance de linguagem, a fim de imprimir essa tal imagem de domínio destes elementos, de impressionar os interlocutores e de convencê-los através da produção de evidências de sentidos. Há toda uma retórica do convencimento que os indivíduos procuram cada vez mais seguir, como modelo, a fim de “passar a sua mensagem”. Desta performance faz parte um modo de enunciação certeiro e firme, sem indecisões, tropeços, sem reticências ou rupturas sintáticas. Em suma: um modo de enunciação determinado, que produza efeitos de certeza (p. 12) (grifos da autora).

É possível também nos referirmos a um tipo de oposição que poderíamos de forma simplista colocar como "silêncio-palavra” com base no que pensa Orlandi (1992) a propósito do tema. A autora afirma que:

O nosso imaginário social [nosso = ocidental, acrescentaríamos] destinou um lugar subalterno para o silêncio. Há uma ideologia da comunicação, do apagamento do silêncio, muito pronunciada nas sociedades contemporâneas. Isto se expressa pela urgência do dizer e pela multidão de linguagens a que estamos submetidos no cotidiano. Ao mesmo tempo, espera-se que se esteja produzindo signos visíveis (audíveis) o tempo todo. Ilusão de controle pelo que "aparece”: temos de estar emitindo sinais sonoros (dizíveis, visíveis) o tempo todo (p. 37) (acréscimo nosso).

Ainda que tenhamos nos concentrado especificamente na questão ideológica do filme, conforme as condições de sua produção nos permitiram observar, a análise também possibilita notar no corpus a materialização desse tipo de ideologia de que fala Orlandi na citação acima. No entanto, importa notar que, a exemplo do filme, essa urgência do dizer precisa ser representada de alguma forma. O silêncio atribuído ao outro no filme é interpretado pelo eu como negativo, já que intervém como indicativo de aversão à sociabilização; todavia, todo esse quadro que faz desfilar duas posturas diferentes é construído ideologicamente. A partir dessa constatação, talvez pudéssemos nos perguntar se, no mundo fora das telas do cinema, 
esse fenômeno também não se repetiria. Ora, para que a ideologia da comunicação possa garantir seu funcionamento, é necessário que haja sempre um “outro” que personifique aquilo que o sujeito “idealizado” pela ideologia da comunicação não é. Será sempre necessário representar esse outro de alguma forma como “diferente”, sem o qual a primeira não prevalecerá. Aqui poderíamos também refletir acerca de determinadas identidades que são construídas e que passam a veicular nos mais diversos setores da sociedade, pressupondo sempre uma relação de poder na qual todo aquele que tem o domínio do discurso (ou das linguagens diversas) tem a possibilidade de exercer sua disciplina não apenas "fazendo o silêncio falar” mas também fazendo, ou, antes, supondo poder fazer, calar o sujeito (ORLANDI, 1992:36).

Ainda que tratando especificamente da argumentação e discurso político, Osakabe (2002) reforça esse nosso raciocínio final ao defender que aquele que enuncia é, "no momento específico em que enuncia, a entidade dominante, na medida em que é ela quem manipula as coordenadas do discurso” (p. 70). Para o autor, tal posição adquirida pelo locutor nesse momento independe de essa dominação coincidir ou não com a dominação efetiva, psicológica ou social. Independentemente do tipo de dominação, entendemos que a ideologia da comunicação a que temos nos referido convida o sujeito a buscar constantemente obter (e manter) a posse da palavra, e isso implica também o domínio de certas técnicas de linguagem (persuasão e engajamento do interlocutor, por exemplo).

Pensando agora essa questão a partir do caráter ideológico dos trechos de filme analisados, com o contraste de duas posturas diante da linguagem, conclui-se que as entidades dominantes buscarão sempre construir representações por meio das quais se legitime e se justifique a necessidade de se manterem no controle das coordenadas do discurso mediante a posse da palavra. No entanto, tais mecanismos estarão sempre sujeitos a uma ordem reguladora, como podemos concluir a partir desta reflexão de Gregolin (2003) quando pensa a “espetacularização da cultura” como um efeito do discurso, à luz do pensamento de Michel Foucault.

Há sempre batalhas discursivas movendo a construção dos sentidos na sociedade. Motivos de disputa, signo de poder, a circulação dos enunciados é controlada de forma a dominar a proliferação dos discursos. Por isso, aquilo que é dito tem de, necessariamente, passar por procedimentos de controle, de interdição, de segregação dos conteúdos. [...] não se pode, absolutamente, falar de uma coisa qualquer num lugar e tempo qualquer. Há, sempre, que se submeter à ordem do discurso, articulando 
aquilo que se pode e se deve dizer no momento histórico da produção dos sentidos (p. 12) (grifo da autora).

Essa ordem reguladora é o que também orientou a realização do trabalho, uma vez que buscamos apontar elementos da representação sobre o outro que remetessem ao seu silenciamento em situações nas quais se observam marcas de modalização e discursos que remetem à valorização dos direitos humanos. Ou seja, há interdições, e o filme talvez nem possa ser acusado de estigmatizar uma certa alteridade, uma vez que insiste, sobretudo por meio da postura de seu protagonista, em promover o respeito, a tolerância e a justiça.

Gostaríamos de concluir refletindo acerca de dois pensamentos de Michel Foucault (1997) que poderiam ser suscitados a propósito das constatações da análise: em primeiro lugar, o princípio de exclusão que existe na sociedade quando se opõem razão e loucura. Em segundo lugar, o caráter de comunicação universal do conhecimento, com a troca indefinida e livre dos discursos. No primeiro caso, diríamos que a urgência do dizer não prevê qualquer dizer, mas um que contenha “verdade”. O autor lembra que, desde a Idade Média, louco “é aquele cujo discurso não pode circular como o dos outros: pode ocorrer que sua palavra seja considerada nula [...] não tendo verdade nem importância” (p. 11). É esse caráter de nulidade que a análise procurou demonstrar ao destacar características da representação da inscrição do outro no filme através de alguma forma de dizer. Na constante relação de poder, esse fenômeno está sempre presente (e não apenas no filme), porém cada vez mais exigindo novas formas de leitura para que possa ser percebido. Em tempos atuais, dada a crescente preocupação com a produção de linguagem politicamente correta, são inconcebíveis afirmações sobre o outro fazendo referência direta à sua "demência” ou carência de simetria, como vimos no Capítulo III, mas os produtos da indústria cultural contemporânea mostram que tais oposições ainda permanecem. O segundo pensamento de Foucault, do caráter de comunicação universal do conhecimento, com a troca indefinida e livre dos discursos, interessa nesse momento de conclusão no ponto em que o autor se refere a esse fenômeno como um dos grandes mitos da cultura européia (ou ocidental, como podemos também entender). Nas narrativas do Ocidente, não se exclui totalmente a possibilidade de que haja coerência, verdade e ciência da parte do Oriente; porém, quando isso ocorre, tais conhecimentos são representados como fechados, inacessíveis e em nada comparáveis com o caráter livre do dizer europeu ou ocidental. Reproduzimos a seguir o excerto da obra de Foucault que ilustra essa nossa última reflexão: 
Gostaria de recordar, sobre este tema, uma anedota que é tão bela que trememos só de a imaginar verdadeira. Ela reduz a uma só figura todas as coerções do discurso: as que limitam os seus poderes, as que dominam as suas aparições aleatórias, as que seleccionam os sujeitos que falam. No início do século XVII, o shogun ouvira dizer que a superioridade dos europeus - em termos de navegação, comércio, política, arte militar - era devida a seus conhecimentos de matemática. Desejou apoderar-se de um saber tão precioso. Como lhe haviam falado de um marinheiro inglês que possuía o segredo desses discursos maravilhosos, ele fê-lo vir ao seu palácio e aí o reteve. A sós com ele, recebeu lições. Aprendeu matemática. E, com efeito, conservou o poder e teve uma longa velhice. Foi só no século XIX que houve matemáticos japoneses. Mas a anedota não termina aí: ela tem a sua vertente européia. A história conta que aquele marinheiro inglês, Will Adams, fora um autodidacta: um carpinteiro que, por ter trabalhado num estaleiro naval, aprendera a geometria. Deve-se ver nesta narrativa a expressão de um dos grandes mitos da cultura européia? Ao saber monopolizado e secreto da tirania oriental, a Europa oporia a comunicação universal do conhecimento, a troca indefinida e livre dos discursos (p.30).

Evidentemente o trabalho não esgota todas as possibilidades de leitura, como o fato de que aqui não foi considerada como ponto central a recepção por parte do espectador, e tampouco pretende se firmar como a única forma possível de leitura. Como bem lembra MacDougall (1998), a interpretação de um filme “depends upon who we are and what assumptions we bring to it [...] with the characteristics of personality, culture, and society that define us” (p.212); no entanto, a abordagem histórico-social com que procuramos analisar o corpus permitiu percebê-lo a partir de diferentes olhares. Espera-se que o trabalho tenha contribuído, sobretudo, no sentido de promover novas formas de leitura que não se restrinjam a compreender um produto fílmico. Todo texto abre sempre um diálogo inevitável com outros textos. 


\section{REFERÊNCIAS BIBLIOGRÁFICAS}

AKCELRUD, I. O Oriente Médio: origem histórica dos conflitos / imperialismo e petróleo / judeus, árabes, curdos e persas. Campinas: Editora da Unicamp, 1986.

ALLEN, M. Árabes. (trad. Denise Bottman). Rio de Janeiro: Nova Fronteira (tít. original: Arabs), 2006.

AMANCIO, T. O Brasil dos gringos: imagens no cinema. Niterói: Intertexto, 2000.

ARBEX JR, J. Guerra Fria: o Estado terrorista. São Paulo: Moderna, 2005.

AUTHIER-REVUZ, J. Entre a transparência e a opacidade: um estudo enunciativo do sentido. (trad. Leci Borges Barbisan e Valdir do Nascimento Flores). Porto Alegre: Edipucrs, 2004.

BASTOS, L.C. e SANTOS, W.S. “Caramba, eu era assim, pelo amor de Deus”: a perspectiva do presente na reconstrução identitária em narrativas de conversão religiosa. IN: MAGALHÃES, I. et al (org.). Práticas identitárias: língua e discurso. São Carlos: Claraluz, 2006.

BECHARA, E. Lições de português pela análise sintática. Rio de Janeiro: Padrão, 1988.

BENDER, T. Nova York em teoria. (trad: Márcio Cavalcanti de Brito Gomes). IN: BERLOWITZ, L., DONOGHUE, D. e MENAND, L. (org). A América em teoria. Rio de Janeiro: Forense (tít. original: America in theory), 1993.

BERCOVITCH, S. The American Jeremiad. Madison: University of Wisconsin, 1978.

BHABHA, H.K. The location of culture. London and New York: Routledge, 1994.

BRANDÃO, H.H.N. Introdução à análise do discurso. Campinas: Editora Unicamp, 2004.

CARMAGNANI, A.M.G. A questão da identidade na mídia: reflexos na sala de aula. IN: CORACINI, M.J. (org.). Identidade \& discurso: (des)construindo subjetividades. Campinas: Unicamp, 2003.

CORACINI, M.J.R.F. A celebração do outro. IN: CORACINI, M.J. (org.). Identidade e discurso: (des)construindo subjetividades.. Campinas: Unicamp, 2003.

DAYAN, D. The Tutor Code of Classical Cinema. IN: NICHOLS, B (org.). Movies and methods: an anthology. Berkeley: University of California Press, 1984.

DUCROT, O. El decir y lo dicho: polifonia de la enunciación. Barcelona: Paidós (tít. original: Le dire et le dit), 1986.

EISELE, J.C. The wild East: deconstructing the language of genre in the Hollywood Eastern. IN: Cinema Journal 41:4 (Summer 2002) 68-94. 
EISENSTEIN, S. O sentido do filme. Rio de Janeiro: Jorge Zahar Editor, 1990.

FAIRCLOUGH, N. Discourse and social change. Cambridge: Polity, 2002.

FERREIRA, A. O império contra-ataca: as guerras de George W. Bush, antes e depois do 11 de setembro. São Paulo: Paz e Terra, 2004.

FOUCAULT, M. A arqueologia do saber. (trad. Luis Felipe Baeta Neves). Rio de Janeiro: Forense Universitária, 1986.

A ordem do discurso. Lisboa: Relógio D’Água Editores, 1997.

GADET, F. e PÊCHEUX, M. A língua inatingível: o discurso na história da lingüística. (trad. Bethania Mariani e Maria Elizabeth Chaves de Mello). Campinas: Pontes (tít. original: La langue introuvable), 2004.

GOROVITZ, S. Os labirintos da tradução: a legendagem cinematográfica e a construção do imaginário. Brasília: Editora UnB, 2006.

Grande Enciclopédia Larousse Cultural. São Paulo: Círculo do livro, 1988.

GREGOLIN, M.R. (org.). Discurso e mídia: a cultura do espetáculo. São Carlos: Claraluz, 2003.

AD: Descrever - interpretar acontecimentos cuja materialidade funde linguagem e história. IN: NAVARRO, P. (org.) Estudos do texto e do discurso: mapeando conceitos e métodos. São Carlos: Claraluz, 2006.

GRIGOLETTO, M. Leituras sobre a identidade: contingência, negatividade e invenção. IN: MAGALHÃES, I. et al (org.). Práticas identitárias: língua e discurso. São Carlos: Claraluz, 2006.

GUIMARÃES, E. Enunciação e acontecimento. IN: Semântica do acontecimento. Um estudo enunciativo da designação. Campinas: Pontes, 2002.

HALL, S. Representation: cultural representations and signifying practices. London: Sage Publications, 1997.

A identidade cultural na pós-modernidade. (trad. Tomaz Tadeu da Silva e Guacira Lopes Louro). Rio de Janeiro: DP\&A (tít. original: The question of cultural identity), 2005.

HOFSTADTER, R. et al. The United States. New Jersey: Prentice-Hall, 1976.

INDURSKY, F. A fragmentação do sujeito em análise do discurso. IN: INDURSKY, F. e CAMPOS, M.C. (orgs.). Discurso, memória, identidade. Porto Alegre: Sagra Luzzatto, 2000.

KARNAL, L. Oriente Médio. São Paulo: Scipione, 1994. 
KELLNER, D. A cultura da mídia - estudos culturais: identidade e política entre o moderno e o pós-moderno. (trad. Ivone Castilho Benedetti). Bauru: Edusc (tít. original: Media culture cultural studies, identity and politics between the modern and postmodern), 2001.

KISSINGER, H. Diplomacy. New York: Touchstone, 1994.

KRESS, G. e VAN LEEWEN, T. Reading images: the grammar of visual design. New York: Routledge, 2001.

LE BRETON, J.M. Reflexões anglófilas sobre a geopolítica do inglês. IN: LACOSTE, Y. (org.). A geopolítica do inglês. São Paulo: Parábola Editorial, 2005.

LEWIS, B. O que deu errado no Oriente Médio (trad. Maria Luiza X. de A. Borges). Rio de Janeiro: Jorge Zahar (tít. original: What went wrong? Western impact and Middle Eastern response), 2002.

Freedom and justice in the modern Middle East. IN: Foreign affairs (May/June 2005), volume 84, number 3. New York: Council on Foreign Relations, 2005.

LOEWEN, J. W. Lies my teacher told me: everything your American history textbook got wrong. New York: The New Press, 1995

JAMESON, F. Marcas do visível. Rio de Janeiro: Graal, 1995.

MACDOUGALL, D. Transcultural cinema. New Jersey: Princeton University Press, 1998.

MACHADO, A. O sujeito na tela. Modos de enunciação no cinema e no ciberespaço. São Paulo: Paulus, 2007.

MARIANI, B. Colonização lingüística. Campinas: Pontes, 2004.

MARTIN, M. A linguagem cinematográfica. (trad. Paulo Neves). São Paulo: Editora Brasiliense (tít. original: Le langage cinématographique), 1990.

MESSADIÉ, G. A crise do mito americano: requiém para o super-homem (trad. Sergio Flaksman). São Paulo: Ática (tít. original: Requiem pour superman: la crise du mythe americain), 1989.

METZ, C. A significação do cinema (trad. Jean-Claude Bernardet). São Paulo: Perspectiva (tít. original: Essais sur la signification au cinéma), 1977.

NICHOLS, B. Ideology and the image. Social representation in the cinema and other media. Bloomington: Indiana University Press, 1981.

NOVAES, A. Por trás do espetáculo: o poder das imagens. IN: NOVAES, A. (org.) Muito além do espetáculo. São Paulo: Senac, 2005.

OLIC, N.B. Oriente Médio: uma região de conflitos. São Paulo: Moderna, 1997.

ORLANDI . Terra à vista: discurso - velho e novo mundo. São Paulo: Cortez, 1990. 

1992.

As formas do silêncio: no movimento dos sentidos. Campinas: Editora da Unicamp, . Análise de discurso: princípios e procedimentos. Campinas: Pontes, 2002.

OSAKABE, H. Argumentação e discurso político. São Paulo: Martins Fontes, 2002.

PAYER, M.O. Linguagem e sociedade contemporânea - Sujeito, mídia, mercado. IN: RUA. Campinas: Unicamp-Nudecri (11: 9-25), 2005.

PÊCHEUX, M. Semântica e discurso: uma crítica à afirmação do óbvio. (trad. Eni Orlandi et al). Campinas: Editora da Unicamp (tít. original: Les vérités de la palice), 1988.

PHILBRICK, N. Mayflower. Nova York: Viking, 2006.

RODINSON, M. La fascinacion del Islam. (trad. Ramón Martínez Castellote). Madrid: Ediciones Júcar (tít. original: La fascination de l’Islam), 1989.

SAID, E.W. Cultura e imperialismo. (trad. Denise Bottman). São Paulo: Companhia das letras (tít. original: Culture and imperialism), 1999.

Orientalismo: o Oriente como invenção do Ocidente (trad. Rosaura Eichenberg). São Paulo: Companhia de Bolso (tít. original: Orientalism: Western conceptions of the Orient), 2007.

SILVA, T. T. Identidade e diferença: a perspectiva dos estudos culturais. Petrópolis: Vozes, 2003.

STAM, R. \& SHOHAT, E. Unthinking eurocentrism: multiculturalism and the media. New York: Routledge, 1997.

TORRES, S. Um dia de fúria em Los Angeles: nostalgia, paranóia e desterritorialização cultural em Falling Down. IN: LIMA, T.M.O. e MONTEIRO, C. (orgs.). Representações culturais do outro nas literaturas de língua inglesa. Niterói: Vício de leitura, 2001.

VANOYE, F. e GOLIOT-LÉTÉ, A. Ensaio sobre a análise fílmica. (trad. Marina Appenzeller). Campinas: Papirus (tít. original: Précis d’analyse filmique), 2005.

VIGNAUX, M. Argumentation et discours de la norme. IN: Langages, no. 53, Paris: Larousse, 1979 (67-86).

WAGNER, P. Sociología de la modernidad (trad. Marciano Villanueva Salas). Barcelona: Herder (tít. original: Soziologie der moderne), 1997.

WATTS, H. Direção de câmera: um manual de técnicas de vídeo e cinema. (trad. Eli Stern). São Paulo: Summus editorial (tít. original: Directing on camera), 1999.

XAVIER, I. O discurso cinematográfico: a opacidade e a transparência. São Paulo: Paz e Terra, 2005. 


\title{
ANEXO 1
}

\section{The Siege (Nova York Sitiada)}

\author{
Ficha Técnica
}

Diretor e realizador: Edward Zwick

Argumento: Lawrence Wright, Menno Meyjes e Edward Zwick, baseado na história de Lawrence Wright

Produção: Lynda Obst e Edward Zwick

Música: Graeme Revell

Ano de lançamento: 1998

Gênero: policial / ação / thriller / drama

Site oficial: http://www.thesiege.com

Estúdio e distribuição: 20th Century Fox / Bedford Falls Productions

Tempo de duração: 115 minutos

Sinopse

O seqüestro do líder religioso Xeique Ahmed Bin Talal, suspeito por comandar o ataque terrorista contra um alojamento militar dos Estados Unidos na Arábia Saudita, provoca uma onda de explosões na cidade de Nova York. Diante dos crescentes ataques, o governo autoriza a declaração de lei marcial. O agente oficial do FBI (Denzel Washington), uma oficial da CIA (Annette Bening) e um general do exército (Bruce Willis) unem forças para capturar os membros de células terroristas espalhadas pela cidade.

Elenco

- Denzel Washington (Anthony ‘Hub’ Hubbard)

- Annette Bening (Elise Kraft / Sharon Bridger)

- Bruce Willis (General William Devereaux)

- Tony Shalhoub (Frank Haddad)

- Sami Bouajila (Samir Nazhde)

- Ahmed Ben Larby (Xeique Ahmed Bin Talal)

- Lianna Pai (Tina Osu)

- Mark Valley (Mike Johanssen)

- Aasif Mandvi (Khalil Saleh) 


\section{ANEXO 2}

Capa do DVD e pôster do filme The Siege (Nova York Sitiada)

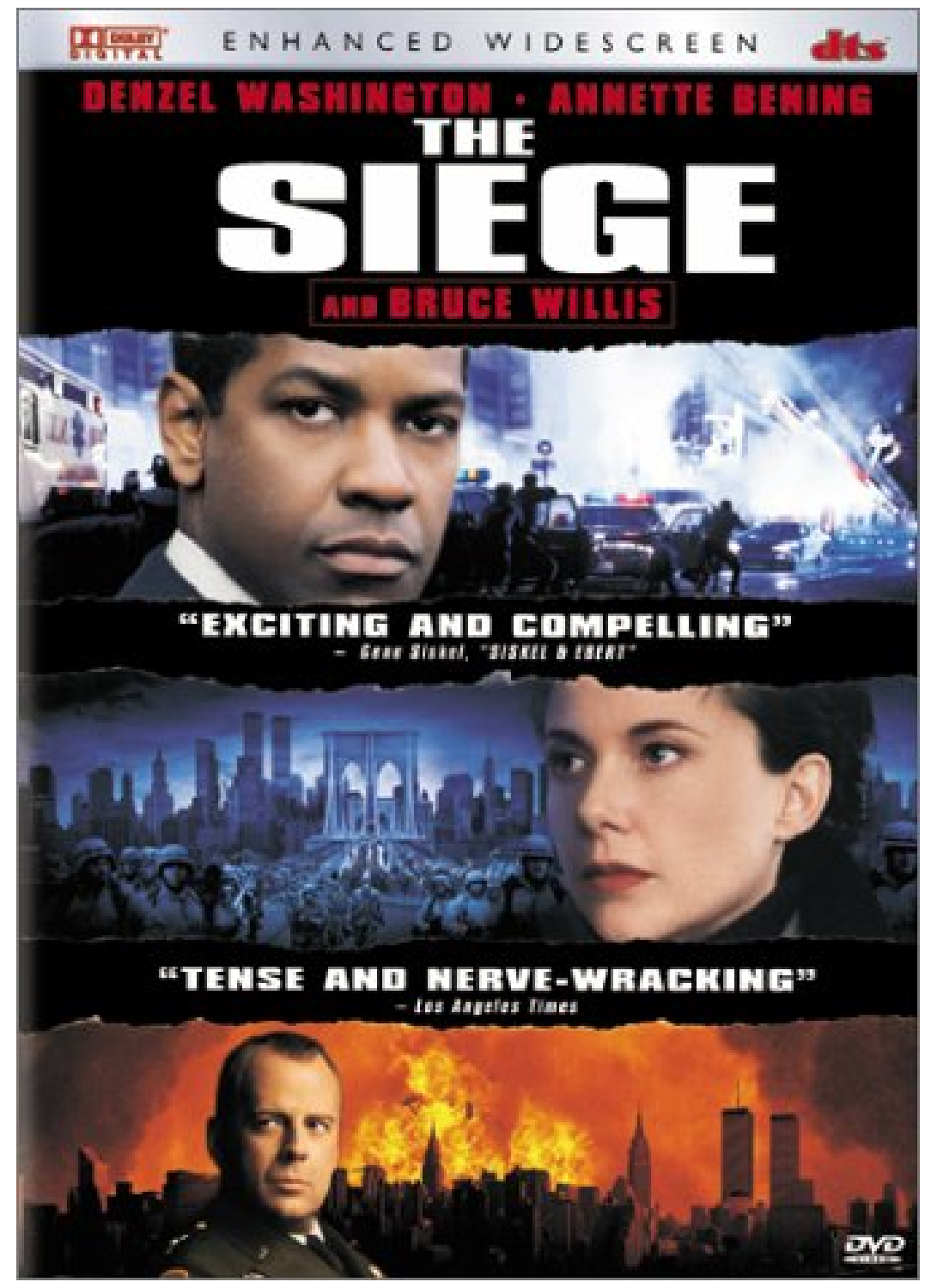

